\title{
STRAY RADIATION MEASUREMENTS AT PARTICLE ACCELERATOR SITES
}

By

J. E. McLaughlin, Jr., Keran O'Brien, Leonard R. Solon, Albert V. Zila, Wayne M. Lowder, and Hanson Blatz

April 1, 1957

This document is PUBLICLY RILAASABLE

Health and Safety Laboratory

New York Operations Office, AEC

and

Division of Research, AEC 
$$
\text { . }
$$ 


\section{DISCLAIMER}

This report was prepared as an account of work sponsored by an agency of the United States Government. Neither the United States Government nor any agency Thereof, nor any of their employees, makes any warranty, express or implied, or assumes any legal liability or responsibility for the accuracy, completeness, or usefulness of any information, apparatus, product, or process disclosed, or represents that its use would not infringe privately owned rights. Reference herein to any specific commercial product, process, or service by trade name, trademark, manufacturer, or otherwise does not necessarily constitute or imply its endorsement, recommendation, or favoring by the United States Government or any agency thereof. The views and opinions of authors expressed herein do not necessarily state or reflect those of the United States Government or any agency thereof. 


\section{DISCLAIMER}

Portions of this document may be illegible in electronic image products. Images are produced from the best available original document. 


\section{ABSTRACT}

Thouplement to Report NYO-4699 performed under the-continuing Accelerator. Survey Program. Stray radiation measurements made at 23 particle accelerator sites are summarized and discussed. Conclusions with regard to safe accelerator operation are drawn, as well as general conclusions regarding radiation dosimetry, maximum permissible levels, and instrumentation. 


\section{ACKNOWLEDGMENTS}

The authors wish to thank everyone who assisted in the implementation of the Accelerator Survey Program. Particularly we acknowledge the contribution of our colleagues in the Health and Safety Laboratory: P. B. Klevin, Martin Weinstein, W. B. Harris, Irving Kingsley, Harold Glauberman, Leo Goodman, H. D. LeVine, Sidney Watnick, Sam Rothenberg, and especially H. J. DiGiovanni, formerly Technical Liaison Division Director.

The authors are also grateful to the representatives of the Chicago and San Francisco Operations Offices who arranged the scheduling of surveys outside the New York jurisdiction. We are especially grateful to the scientists at the various accelerator sites who assisted the surveyors, namely, W. Ernst of the Memorial Center for Cancer and Allied Diseases; W. G. Wadey of Yale University; J. Gorman of the Carnegie Institute of Technology; C. E. Mandeville and G. McClure of the Bartol Research Foundation; R. F. Mozeley and C. Olsen of Stanford University; W. Patterson, B. Thompson, R. Wallace, and A. Smith of the University of California Radiation Laboratory; T. C. Evans and R. Rhody of the State University of Iowa; R. Wollan of the University of Minnesota; D. J. Tandam, T. R. Palfrey, and J. W. MacKay of Purdue University; D. J. Stearman of the University of Illinois; F. Hereford of the University of Virginia; J. Storey of the University of Chicago; W. Moos of the University of Illinois Medical School; C. C. Palmiter of the University of Michigan; and the other accelerator personnel at all the sites.

Last, but not least, the authors wish to express their gratitude for the careful preparation of reports by Pauline Castellani and Josephine Lemma, as well as by our former assistants, Yvette Rosenberg and Regina Bedner. 


\section{CONTENTS}

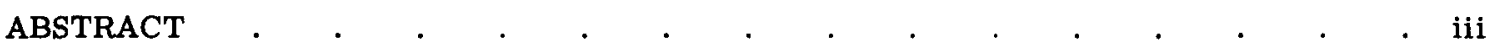

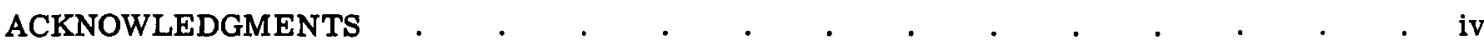

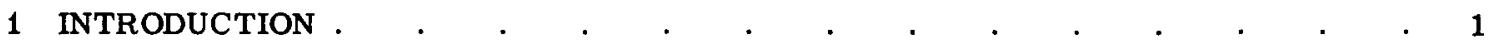

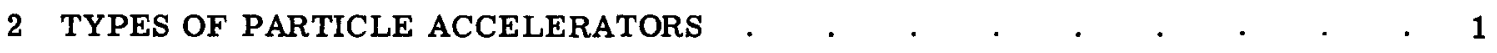

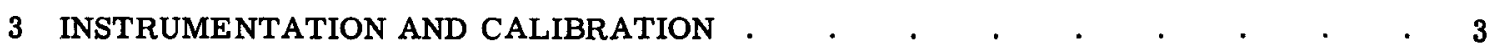

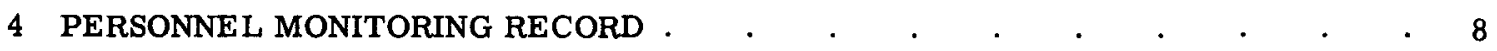

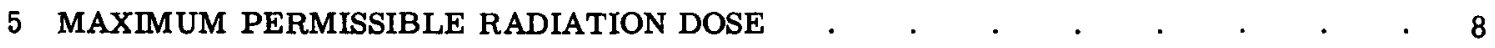

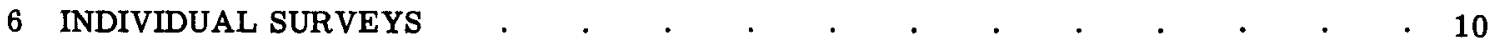

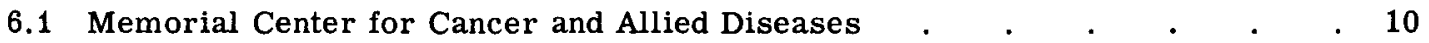

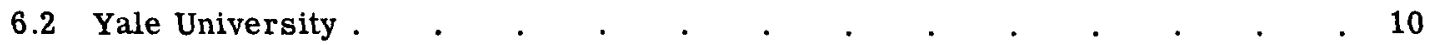

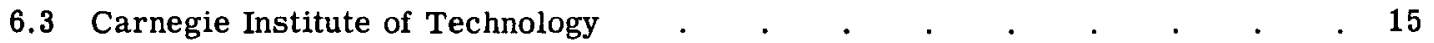

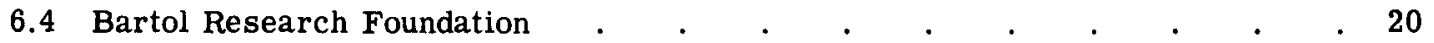

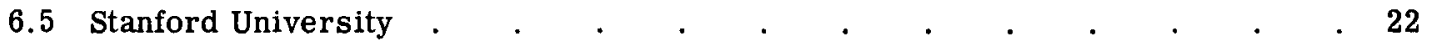

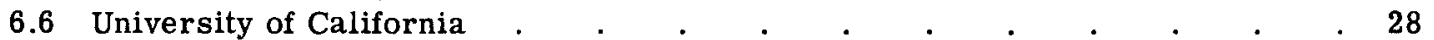

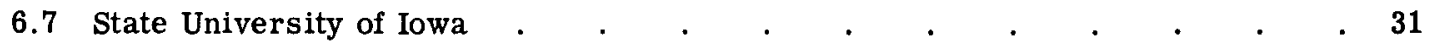

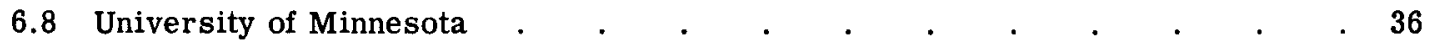

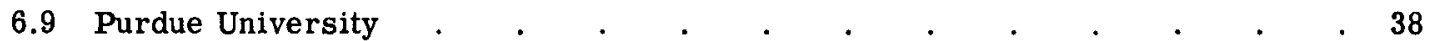

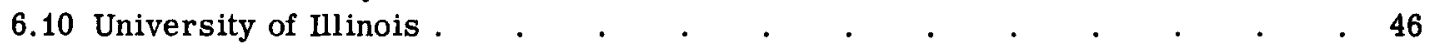

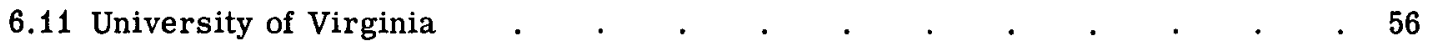

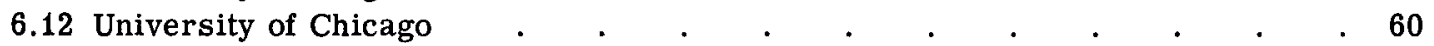

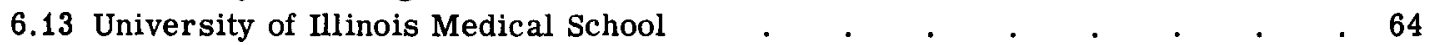

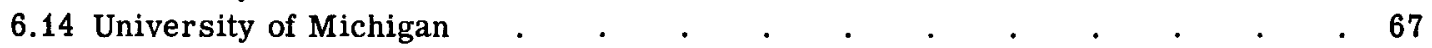

7 CONCLUSIONS AND RECOMMENDATIONS $\quad . \quad$. $\quad . \quad$. $\quad . \quad$. $\quad . \quad$. $\quad$. 74

\section{ILLUSTRATIONS}

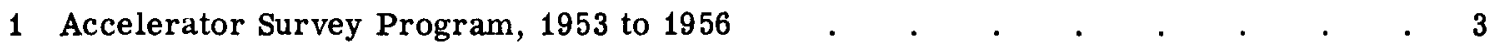

2 Graphite $-\mathrm{CO}_{2}$ Ionization Chamber . . . . . . . . . . . . . 5

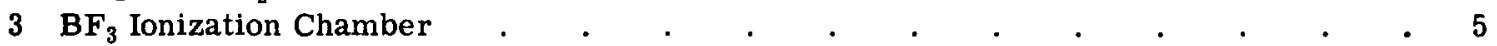

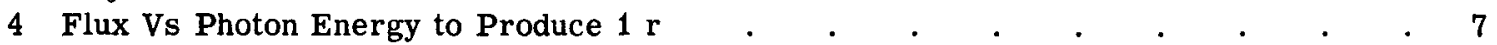

Memorial Center for Cancer and Allied Diseases 22.5-Mev Betatron Layout,
Dec, 21, 1954 . . . . . . . 11 
6 Yale University Linear Accelerator Layout, January 1955

7 Electron Absorption Measurements at Yale University Linear Accelerator, January 1955

8 Carnegie Institute of Technology NRC Synchrocyclotron Layout, February 1955

9 Bartol Research Foundation Cockcroft-Walton Accelerator Layout, March 1955

Stanford University Mark III Linear Electron Accelerator Layout, April 1955

Stanford University, Earth Shield at Beam End of Linear Electron

Accelerator

University of California Radiation Laboratory Bevatron Layout, 1955 .

University of California Radiation Laboratory Bevatron

University of California Radiation Laboratory Synchrocyclotron Layout, 1955 University of California Radiation Laboratory Synchrocyclotron State University of Iowa Van de Graaff Generator Layout, July 1955 $\cdot \cdot 34$ State University of Iowa Cockcroft-Walton Accelerator Layout, July 1955 . $\quad$. $\quad$ - 35 University of Minnesota Linear Accelerator Layout . . . . . . . . . . 36

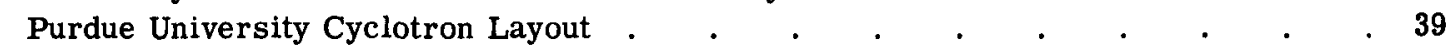

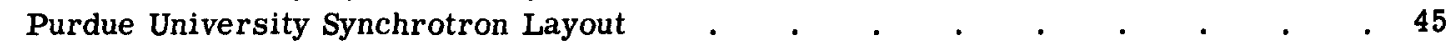

Purdue University Linear Electron Accelerator Layout $\quad$. . . . . . . . . 45

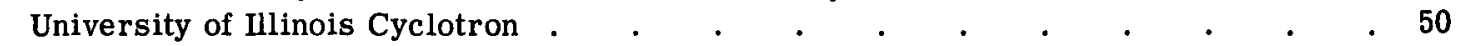

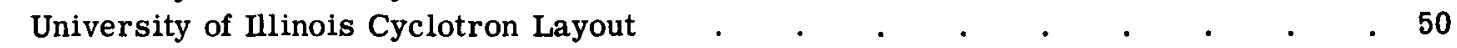

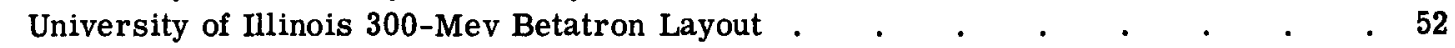

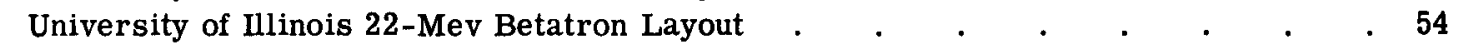

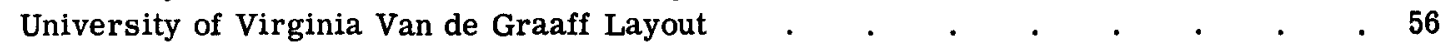

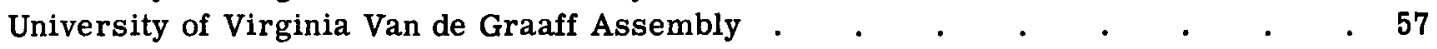

University of Virginia Van de Graaff, North Shield Wall and Control Panel . . $\quad$. 57

University of Chicago Synchrocyclotron and Betatron Layout, September 1956

31 University of Chicago Cockcroft-Walton Accelerator .

32 University of Illinois Medical School Betatron Layout

33 University of Illinois Medical School Betatron, Courtyard and Adjacent Area

34 University of Michigan Cyclotron Layout, December 1956

35 University of Michigan, Floor Above Cyclotron, December 1956 . . . . . $\quad$. 69

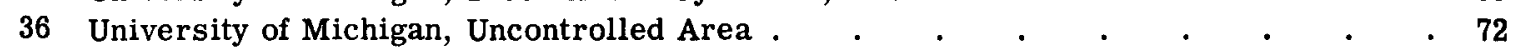

37 University of Michigan Synchrotron Layout, December $1956 \quad$. $\quad . \quad$. $\quad . \quad$. 72

\section{TABLES}

1 Particle Accelerators Surveyed from December 1954 Through December 1956

2 Summary of $\gamma / \phi$ Values

3 Summary of Film Badge Records

4 Stray Radiation Measurements at 22.5-Mev Betatron (Dec. 21, 1954)

$5 \mathrm{X}$-radiation Levels at Yale University Linear Accelerator (Jan. 13, 1955)

6 Radiation Levels During Production of 1.3-Mev Neutrons by $(\gamma, \mathrm{n})$ in Gold at Yale University Linear Accelerator (Jan. 13, 1955). 


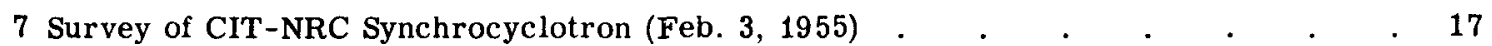

8 Survey of CIT-NRC Synchrocyclotron (Feb. 3, 1955) $\quad . \quad$. $\quad . \quad$. $\quad . \quad$. $\quad . \quad 18$

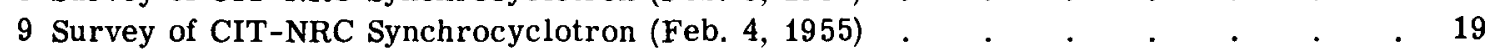

10 Bartol Research Foundation Cockcroft-Walton Accelerator (Mar. 22-23, 1955)

11 Bartol Research Foundation Cockcroft-Walton Accelerator (Mar. 22-23, 1955)

12 Survey Data, First Run (P.M. Apr. 12 to A.M. Apr. 13, 1955)

13 Survey Data, Second Run (P.M. Apr. 13, 1955)

14 Survey Data, Third Run (A.M. Apr. 14, 1955)

15 Summary of Stray Radiation Measurements at University of California Radiation Laboratory Bevatron (Apr. 19, 1955) . . . . . Radiation Laboratory 184-in. Synchrocyclotron (Apr. 19, 1955) . . . . $\quad$. $\quad 33$

17 State University of Iowa 5-Mev Van de Graaff (July 11, 1955) . . . . $\quad$. $\quad$. 34

18 State University of Iowa $400-\mathrm{Kev}$ Cockcroft-Walton Generator . . . 35

19 Summary of Inside Measurements at University of Minnesota Linac (July 1955) .

20 Summary of Outside Measurements at University of Minnesota Linac (July 1955) .

21 Purdue University Cyclotron (Oct. 3-4, 1955)

22 Purdue University Cyclotron (Oct. 4, 1955) .

23 Summary of $\mathrm{BF}_{3}$ Ionization Chamber Measurements for Cyclotron Condition in Table 21

24 Summary of $\mathrm{BF}_{3}$ Ionization Chamber Measurements for Cyclotron Condition in Table 22

25 Purdue University 300-Mev Electron Synchrotron (Oct. 5, 1955) . . . . . . 44

26 Purdue University Linear Accelerator (Oct. 5, 1955) . . . . . . . . 47

27 Summary of Radiation Levels at University of Illinois Cyclotron (October 1955) . . 48

28 Summary of Radiation Levels at University of Illinois Cyclotron (October 1955) . 49

29 Summary of Radiation Levels at University of Illinois 300-Mev Betatron (Oct. 7, 1955)

30 Summary of $\mathrm{BF}_{\mathbf{3}}$ Ionization Chamber Measurements at University of Illinois 300-Mev Betatron

31 Summary of Radiation Levels at University of Illinois 22-Mev Betatron (Oct. 7, 1955)

32 Summary of Radiation Levels for Deuteron Beam on Tritium Target Without Collimator at University of Virginia Van de Graaff (September 1956) .

33 Summary of Radiation Levels for Deuteron Beam on Tritium Target with Aluminum Collimator at University of Virginia Van de Graaff

34 Summary of Radiation Levels for Deuteron Beam on Deuterium Target at University of Virginia Van de Graaff .

35 Radiation Levels at University of Chicago Synchrocyclotron (September 1956)

36 Radiation Levels at University of Chicago Betatron (September 1956) .

37 Radiation Levels at University of Chicago Cockcroft-Walton Accelerator (September 1956).

38 Radiation Levels at University of Illinois Medical School Betatron (September 1956).

39 Summary of Radiation Measurements at University of Michigan Cyclotron (December 1956).

40 Summary of Radiation Measurements at University of Michigan Cyclotron (December 1956). 
41 Summary of Radiation Measurements at University of Michigan Cyclotron (December 1956) .

42 Summary of Radiation Levels at University of Michigan Synchrotron

(December 1956) 


\section{STRAY RADIATION MEASUREMENTS AT PARTICLE ACCELERATOR SITES}

\section{INTRODUCTION}

Stray radiation surveys performed in 1953 and 1954 at 15 particle accelerator sites by the Health and Safety Laboratory (HASL) of the New York Operations Office were summarized earlier. ${ }^{1}$ This second report presents data and conclusions obtained during subsequent surveys conducted at 23 machines between December 1954 and December 1956. Thus the two reports represent a fairly complete picture of the radiation problems generally encountered at accelerators, including the five synchrocyclotrons in the United States as well as several other very high energy machines.

The measurements indicated that the radiation problems at older accelerators, most of which are located on university campuses, have tended to be a little troublesome with regard to unregulated outside areas and classroom buildings. The newer machines, in general, are in more remote locations; therefore, the principal radiation protection problem has to do with the unknowns in high-energy radiation dosimetry. As pointed out in the earlier report, personnel monitoring records show that the bulk of the measurable radiation exposures represent relatively few of the accelerator experimenters.

\section{TYPES OF PARTICLE ACCELERATORS}

Some excellent descriptions of accelerators have appeared in the literature $e^{2,3}$ and are recapitulated in Report NYO-4699. Consequently, accelerator types or particular machines will be discussed only briefly, in order to explain the technique and analysis of stray radiation measurements.

The 23 radiation surveys were performed at the sites listed in Table 1 . The energy of the accelerated particle at the time of the survey is also shown. The nature of the resulting radiation field for given beam conditions is discussed in Sec. 6 .

The technique of an individual survey is determined by the nature of the available instrumentation and by the characteristics of the accelerator. An electron accelerator survey will consist principally of evaluating the $x$-radiation levels resulting from interactions of the beam electrons with the target materials and the various accelerator parts. The stray neutron problem was often of secondary importance, although neutrons were the principal component of the stray radiation levels at two sites, a betatron and a large linear accelerator which produced $500-\mathrm{Mev}$ electrons at the time of the survey. Both cases are discussed later.

A positive ion accelerator survey is principally a problem in neutron dosimetry. Experience has shown that $x$-radiation levels in work areas near cyclotrons, Van de Graaff generators, and Cockcroft-Walton accelerators, as well as synchrocyclotrons, are rarely important during shutdown except inside the radiation shield near the machine itself. Frequently it was found that the neutron energies were too low to affect fast neutron detectors significantly because of the $x$-radiation discrimination in these instruments. It was also found that the neutron energies were too great for efficient thermal neutron detection. In such instances ionization 
Table 1-PARTICLE ACCELERATORS SURVEYED FROM DECEMBER 1954 THROUGH DECEMBER 1956

\begin{tabular}{|c|c|c|c|c|c|}
\hline Installation & $\begin{array}{c}\text { Type of } \\
\text { accelerator }\end{array}$ & Dimensions & $\begin{array}{r}\text { Accelerated } \\
\text { energy,* }\end{array}$ & $\begin{array}{l}\text { particle } \\
\text { Mev }\end{array}$ & Date surveyed \\
\hline $\begin{array}{l}\text { Memorial Center for Cancer and } \\
\text { Allied Diseases, New York }\end{array}$ & Betatron & $20-\mathrm{cm}$ orbit radius & 22.5 & $5 \mathrm{e}$ & Dec. 21, 1954 \\
\hline Yale University & Linear accelerator & 9-ft 4-in. cavity assembly & 4 & $\mathrm{e}$ & $\begin{array}{l}\text { Dec. } 29,1954 \\
\text { Jan. } 13,1955\end{array}$ \\
\hline $\begin{array}{l}\text { Carnegie Institute of Technology, } \\
\text { Nuclear Research Center }\end{array}$ & Synchrocyclotron & 142-in. pole piece diameter & 440 & $\mathbf{p}$ & Feb. $3-4,1955$ \\
\hline Bartol Research Foundation & Cockeroft-Walton & & 0.1 & $\mathrm{~d}$ & Mar, $22-23,1955$ \\
\hline $\begin{array}{l}\text { Stanford University, High } \\
\text { Energy Physics Laboratory }\end{array}$ & Linear accelerator & $220 \mathrm{ft}$ long & 500 & $\mathrm{e}$ & Apr. $12-14,1955$ \\
\hline $\begin{array}{l}\text { University of California, } \\
\text { Berkeley Radiation Laboratory } †\end{array}$ & $\begin{array}{l}\text { Synchrocyclotron } \\
\text { Bevatron }\end{array}$ & $\begin{array}{l}\text { 184-in. pole piece diameter } \\
600 \text {-in. orbit radius }\end{array}$ & $\begin{array}{r}340 \\
4800\end{array}$ & $\begin{array}{l}\mathrm{p} \\
\mathrm{p}\end{array}$ & Apr. $18-19,1955$ \\
\hline State University of Iowa & $\begin{array}{l}\text { Van de Graaff } \\
\text { Cockcroft-Walton }\end{array}$ & $\begin{array}{l}22-\mathrm{ft} \text { tube } \\
5-\mathrm{ft} \text { tube }\end{array}$ & $\begin{array}{l}2 \\
0.4\end{array}$ & $\mathrm{p}$ & July $11-12,1955$ \\
\hline University of Minnesota & Linear accelerator & $100 \mathrm{ft}$ long & 40 & $\mathrm{p}$ & July $13-14,1955$ \\
\hline Purdue University & $\begin{array}{l}\text { Cyclotron } \\
\text { Synchrotron } \\
\text { Linear accelerator }\end{array}$ & $\begin{array}{l}37 \text {-in. pole piece diameter } \\
100-\mathrm{cm} \text { orbit radius } \\
12 \mathrm{ft} \text { long }\end{array}$ & $\begin{array}{r}10 \\
300 \\
5.5\end{array}$ & d & Oct. $4-5,1955$ \\
\hline University of Illinois & $\begin{array}{l}\text { Cyclotron } \\
\text { Betatron } \\
\text { Betatron }\end{array}$ & $\begin{array}{l}47-\mathrm{in} . \text { pole piece diameter } \\
19.5-\mathrm{cm} \text { orbit radius } \\
120-\mathrm{cm} \text { orbit radius }\end{array}$ & $\begin{array}{r}10 \\
20 \\
300\end{array}$ & $\mathrm{~d}$ & Oct. $6-7,1955$ \\
\hline University of Virginia & Van de Graaff & $\sim 5 \mathrm{ft}$ long & 2 & $d$ & Sept. $12-13,1956$ \\
\hline University of Chicago & $\begin{array}{l}\text { Synchrocyclotron } \\
\text { Betatron } \\
\text { Cockcroft-Walton }\end{array}$ & $\begin{array}{l}170-\text { in. pole piece diameter } \\
33-\text { in. orbit radius }\end{array}$ & $\begin{array}{r}450 \\
100 \\
0.5\end{array}$ & $\begin{array}{l}\mathrm{p} \\
\mathrm{e} \\
\mathrm{d}\end{array}$ & Sept. $24-26,1956$ \\
\hline $\begin{array}{l}\text { University of Illinois } \\
\text { Medical School }\end{array}$ & Betatron & $19.5-\mathrm{cm}$ orbit radius & 25 & $\mathrm{e}$ & Sept. 27,1956 \\
\hline University of Michigan & $\begin{array}{l}\text { Cyclotron } \\
\text { Synchrotron }\end{array}$ & $\begin{array}{l}42-\text { in. pole piece diameter } \\
40-\text { in. orbit radius }\end{array}$ & $\begin{array}{r}8 \\
80\end{array}$ & $\begin{array}{l}\mathrm{d} \\
\mathrm{e}\end{array}$ & Dec. $4-5,1956$ \\
\hline
\end{tabular}

* Energy at time of survey.

$\dagger$ Primarily an instrument intercalibration. 
chamber techniques were successfully employed. The "long" counter" was found to be useful in evaluating intermediate energy neutron fluxes near constant current accelerators.

Special survey techniques had to be employed at some of the sites. For example, the Bevatron was pulsed about 16 times/min with about 4-sec delays between pulses. Consequently, rate-meter instrumentation was useless, and the total ionization or the total counts that occurred during a known number of pulses (or the acceleration of a known number of protons) had to be measured with integrating devices. In this way different measurements were correctly normalized and compared.

Of course, when ionization chamber devices were used, corrections for "background" were made. Measurements made at other accelerators, such as the high-energy traveling-wave linear accelerator, had to be further corrected to account for the effect of $x$ rays due to highpower klystron amplifier tubes.

Occasionally it was necessary to demonstrate that magnetic fields near machines such as synchrotrons were not interfering with the survey instrumentation. During one survey the instruments were shielded with grounded screens to reduce the effect of electrical interference. Other problems encountered at particular accelerator sites, or with particular instrumentation, are discussed in Secs. 3 and 6.

\section{INSTRUMENTATION AND CALIBRATION}

The stray radiation measurements were made with a variety of instruments acquired over the past four years. Some of the devices are commercially available and some represent modifications or developments undertaken to resolve specific survey problems. The nucleus of HASL survey equipment consists of ionization chambers used in conjunction with vibrating-reed electrometers. Ionization chambers, being relatively rugged and insensitive to miscellaneous interference (e.g., $r$-f pickup and $x$-ray pile-up), have been found to have the most general applicability for field work.

In the survey work the equipment is often transported over long distances (Fig. 1). The survey instruments are carefully packed in padded fiberboard cases and shipped, usually by air freight. One trip requires 300 or $400 \mathrm{lb}$ of equipment, which must be in working order at the end of the trip. With the same degree of care in handling, the ionization chamber devices have fared better than the scintillation and proportional neutron counter equipment.

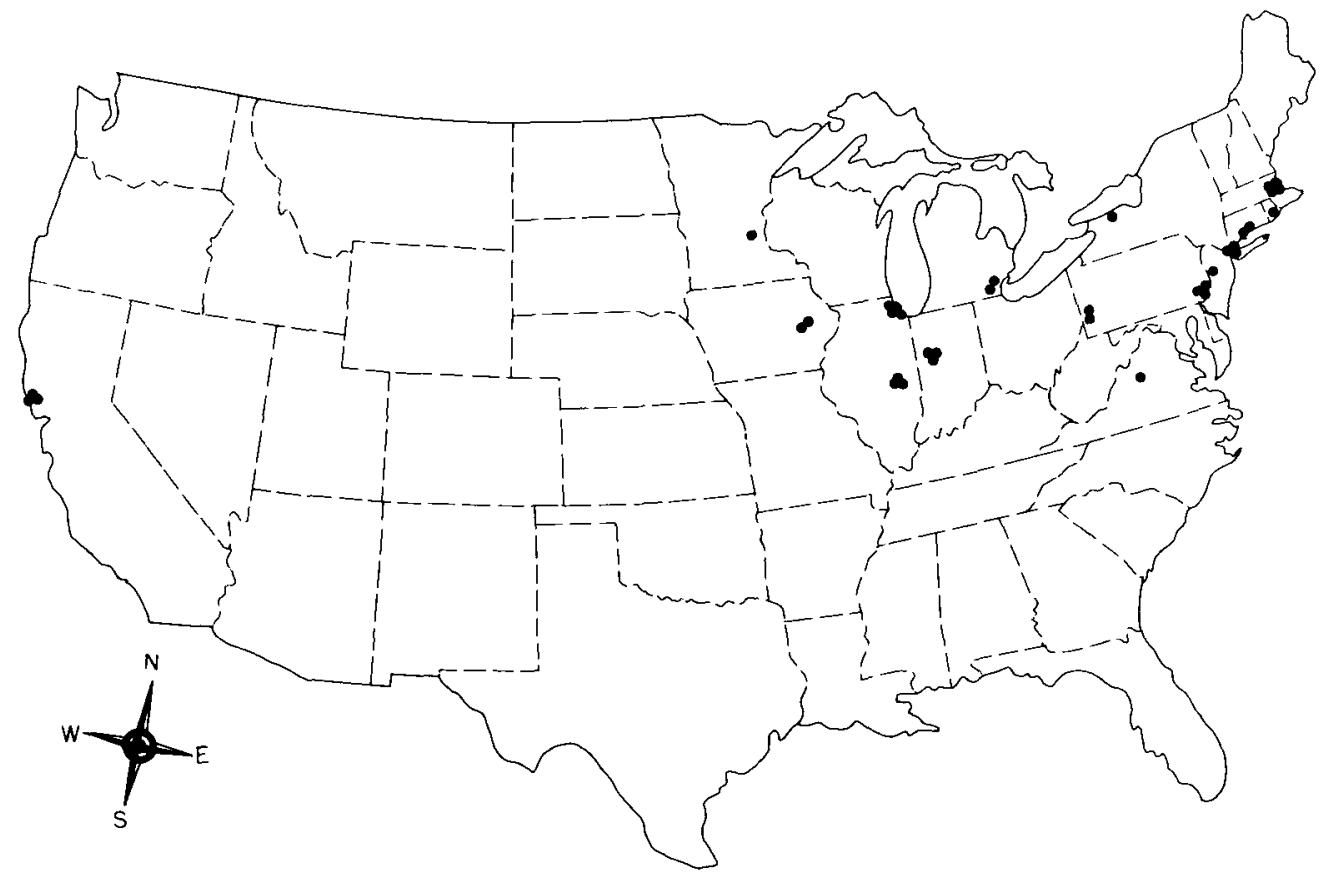

Fig. 1-Accelerator survey program, 1953 to 1956. 
Three ionization chambers were employed to obtain estimates of the neutron fluxes and $x$-ray dose rates. One, the Failla-Rossi Tissue Equivalent Chamber (as well as its use in accelerator surveys) has been described. ${ }^{1,5}$ The second, a graphite chamber, is filled with $\mathrm{CO}_{2}$ at a pressure of about $1 / 2$ atmosphere. The graphite wall is about $3 / 8$ in. thick, and the chamber is sealed in a thin aluminum container to ensure gas tightness (Fig. 2). The third chamber is made of stainless steel and filled with $\mathrm{BF}_{3}$ enriched in the isotope $\mathrm{B}^{10}$ (Fig. 3). The $\mathrm{BF}_{3}$ chamber was surrounded with a polyethylene moderator thick enough to produce an optimum response to Po-Be neutrons.

If two or more ionization chambers having different atomic compositions are exposed to a mixed radiation field, it is possible to determine the $\mathrm{x}$ - or gamma-radiation dose and the neutron flux if the energies are known. Examples of this procedure have appeared in the literature. ${ }^{6-8}$ The technique as it was applied to the accelerator surveys will be discussed here.

The response of an ionization chamber to a mixture of $x$ radiation and neutrons can be represented by

$$
\mathbf{R}=\mathbf{k} \gamma+\mathbf{g} \phi
$$

where $\gamma$ and $\phi$ are the $x$-ray dose rates and the neutron fluxes, respectively. The values of the calibration constants $\mathrm{k}$ and $\mathrm{g}$ depend upon the energies of the radiations of interest and the sensitivity of the chamber to these radiations.

Designating as $p(E)$ the flux of neutrons having an energy of $E(M e v)$, which produces a dose rate of $1 \mathrm{mrep} * / \mathrm{hr}$ in the irradiated material, and assuming that the energy causing ionization is produced by elastic collisions only (the predominant interaction for neutrons below $20 \mathrm{Mev}$ ), gives ${ }^{7}$

$$
p(E)=\frac{8.07 M}{E L}\left[\sum_{i=1}^{n} \frac{\sigma(E) x_{i} A_{i}}{(1+A)^{2}}\right]^{-1}
$$

In this equation $L$ is Avogadro's number, $M$ is the molecular weight of the material in question, $\sigma(E)$ is the microscopic cross section in square centimeters for a given atomic species of weight $A$, and $x$ is the frequency of appearance of the species in the molecule.

Since neutrons have an energy distribution $N(E)$, the flux of the neutron distribution which deposits $1 \mathrm{mrep} / \mathrm{hr}$ is expressed by

$$
p=\frac{\int_{0}^{\infty} N(E) d E}{\int_{0}^{\infty}[N(E) / p(E)] d E}
$$

Values of $\mathbf{p}$ for Po-Be neutrons, which were used in the calibration of the tissue equivalent and graphite chambers, were obtained by evaluating Eqs. 1 and 2 by integrating with Simpson's rule at $0.2-\mathrm{Mev}$ intervals over the Po-Be spectrum. ${ }^{9}$ The values of $\mathrm{p}$ are $464 \mathrm{n} / \mathrm{cm}^{2}-\mathrm{sec} / \mathrm{mrep} /$ $\mathrm{hr}$ for $\mathrm{CO}_{2}$ and $63 \mathrm{n} / \mathrm{cm}^{2}-\mathrm{sec} / \mathrm{mrep} / \mathrm{hr}$ for tissue on a single-collision basis.

The tissue responses of two ionization chambers are, then

$$
\begin{aligned}
& \mathbf{R}_{1}=\mathbf{k}_{1} \gamma+\left(\mathrm{k}_{1} / \mathrm{p}_{1}\right) \phi \\
& \mathbf{R}_{2}=\mathbf{k}_{2} \gamma+\left(\mathrm{k}_{2} / \mathrm{p}_{2}\right) \phi
\end{aligned}
$$

and the solutions are

$$
\begin{aligned}
& \phi=\frac{\mathrm{p}_{1} \mathrm{p}_{2}}{\mathrm{p}_{1}-\mathrm{p}_{2}}\left(\frac{\mathrm{R}_{2}}{\mathrm{k}_{2}}-\frac{\mathrm{R}_{1}}{\mathrm{k}_{1}}\right) \mathrm{n} / \mathrm{cm}^{2}-\mathrm{sec} \\
& \gamma=\frac{1}{\mathrm{p}_{1}-\mathrm{p}_{2}}\left(\frac{\mathrm{R}_{1} \mathrm{p}_{1}}{\mathrm{k}_{1}}-\frac{\mathbf{R}_{2} \mathbf{P}_{2}}{\mathrm{k}_{2}}\right) \mathrm{mrep} / \mathrm{hr}
\end{aligned}
$$

* The obsolete millirep is used to simplify the presentation of the early survey data discussed in this report. Of course, ${ }^{7} \mathrm{p}(\mathrm{E})$ in units of $\mathrm{mrad} / \mathrm{hr} / \mathrm{n} / \mathrm{cm}^{2}-\mathrm{sec}$ would be

$$
p(E)=\frac{8.68 \mathrm{M}}{E L}\left[\sum_{i=1}^{n} \frac{o(E) x_{i} A_{i}}{(1+A)^{2}}\right]^{-1}
$$




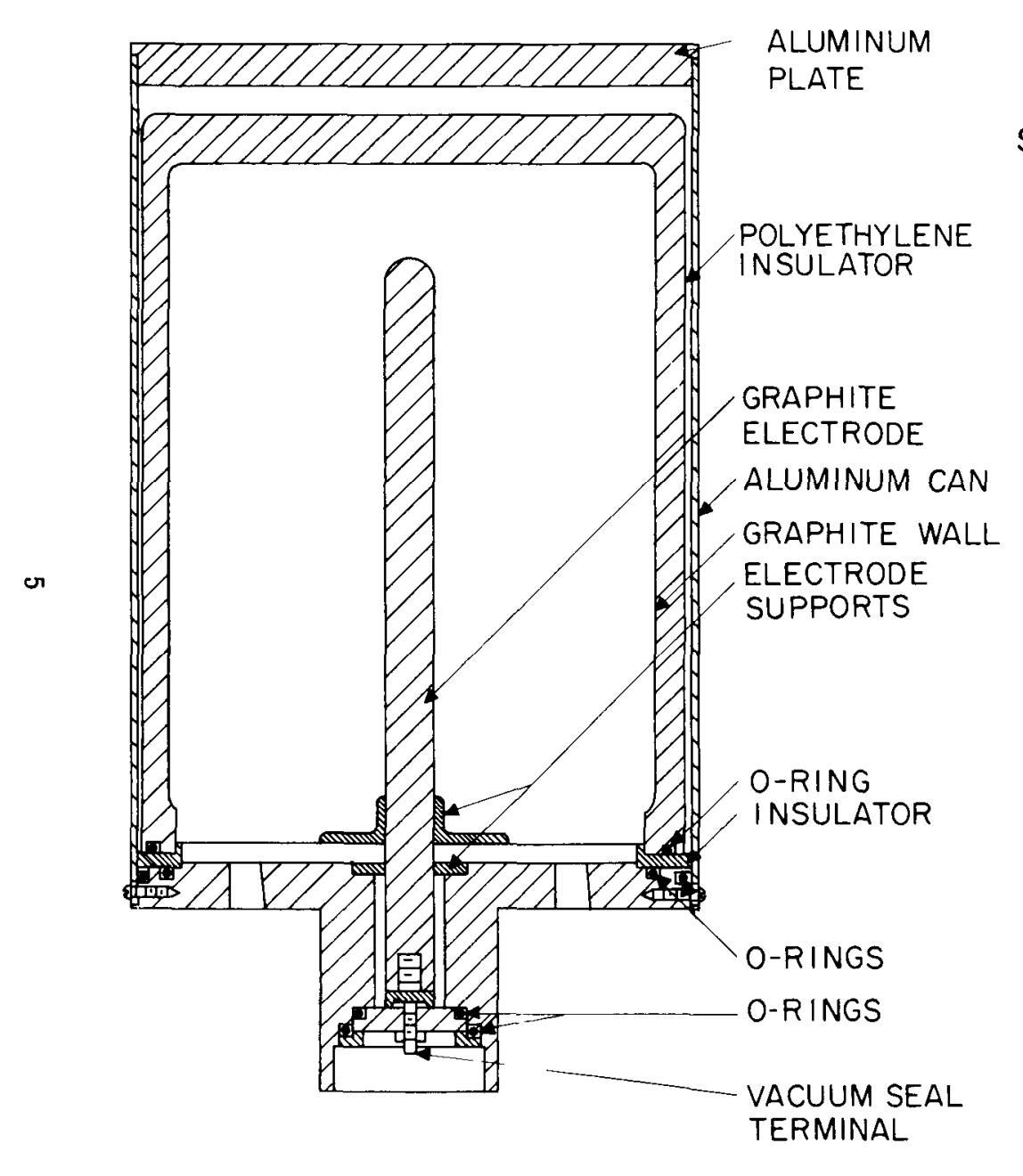

Fig. 2-Graphite- $\mathrm{CO}_{2}$ ionization chamber (approxımately half-sıze).

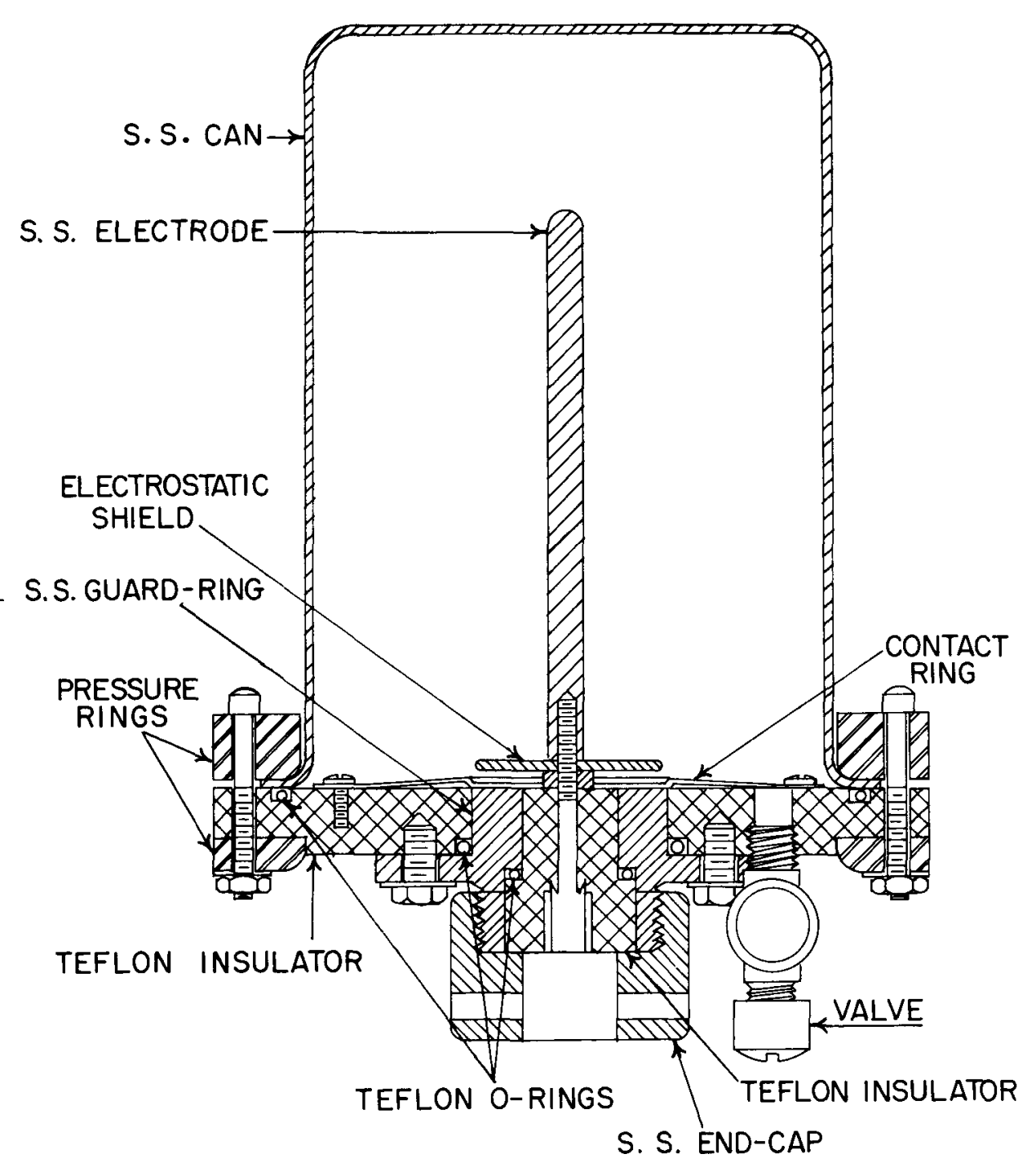

Fig. 3- $\mathrm{BF}_{3}$ ionızation chamber (approxımately actual sıze). 
Values for the k's were obtained for each chamber by using a standard encapsulated radium source. Thus, measurements were made of stray radiations with two ionization chambers, and Eq. 3 permitted the calculation of $\phi$, the equivalent Po-Be neutron flux, and $\gamma$, the equivalent radium gamma-ray dose rate.

In the early surveys only the tissue equivalent and graphite chamber combinations were used to estimate $\phi$ and $\gamma$. However, two serious limitations in the procedure were apparent. First, significant departures of the stray neutron spectrum from the Po-Be spectrum were not detectable except by noticing apparent inconsistencies between the ionization chamber data and measurements made with other instruments. Second, the currently accepted fast neutron relative biological effectiveness (RBE) ${ }^{10}$ of 10 effectively reduces the sensitivity of the tissue equivalent chamber to fractions of neutron maximum permissible dose rate by a factor of 10 . This is, when the tissue equivalent chamber is subject to equal amounts of $x$ rays and neutrons on a tissue damage basis, the chamber measures the neutron intensity only as $1 / 10$ of the $x$-ray contribution on a physical dose basis. For these reasons the $\mathbf{B F}_{3}$ chamber, which has a greatly enhanced response to neutrons compared to the tissue equivalent chamber, was incorporated into the HASL survey technique.

The value of $\mathrm{p}$ for Po-Be neutrons and the polyethylene-moderated $\mathrm{BF}_{3}$ chamber was determined experimentally from

or

$$
\begin{aligned}
& \mathrm{R}_{\mathrm{BF}_{3}}=\mathrm{k}_{\mathrm{BF}_{3}} \gamma+\left(\mathrm{k}_{\mathrm{BF}_{3}} / \mathrm{p}_{\mathrm{BF}_{3}}\right) \phi \\
& \mathrm{p}_{\mathrm{BF}_{3}}=\frac{\mathrm{k}_{\mathrm{BF}_{3}}}{(\mathrm{R} / \phi)-(\gamma / \phi) \mathrm{k}_{\mathrm{BF}_{3}}}
\end{aligned}
$$

The evaluation of $p$ depended upon the $\mathrm{x}$ - or gamma-ray calibration of the $\mathrm{BF}_{3}$ chamber and the gamma-ray output of the neutron source. The value of $\gamma / \phi$ was found to be $0.0039 \mathrm{mrep} / \mathrm{hr} / \mathrm{n} /$ $\mathrm{cm}^{2}-\mathrm{sec}$. Other values of $\gamma / \phi$ for Po-Be neutron sources have been reported ${ }^{11,12}$ and are summarized in Table 2.

Table 2 -SUMMARY OF $\gamma / \phi$ VALUES

\begin{tabular}{cc}
\hline Reference & $\gamma / \phi, \mathrm{mrep} / \mathrm{hr} / \mathrm{n} / \mathrm{cm}^{2}-\mathrm{sec}$ \\
\hline Johns $^{11}$ (Fig. 4) & 0.0052 \\
Rausa $^{12}$ & 0.0046 \\
\hline
\end{tabular}

The ratio $\mathrm{R} / \phi$ is theoretically a constant, but the extreme sensitivity of the $\mathrm{BF}_{3}$ chamber to scattered neutrons makes this ratio difficult to determine. If $\phi^{\prime}$ is the primary neutron flux 1 meter from the source, then the flux at a distance $x$ is $\phi=\phi^{\prime} / x^{2}$. But the neutron response of an ionization chamber is $\mathrm{R}=\mathrm{g} \phi$, thus

$$
\mathrm{g}(\mathrm{x})=\mathbf{R} / \phi=\mathbf{R x}^{2} / \phi^{\prime}
$$

The $\mathrm{BF}_{3}$ chamber was exposed to a Po-Be source, and a plot of $\mathrm{Rx}^{2}$ as a function of $\mathrm{x}$ was obtained. The curve between the smallest distance to several meters was linear, i.e., $\mathbf{g}(\mathrm{x})=$ $\mathrm{mx}+\mathrm{b}$. At $\mathrm{x}=0, \mathrm{~g}(\mathrm{x})$ was taken to be a sufficiently good approximation of $\mathrm{R} / \phi=1.565 \mathrm{n} / \mathrm{cm}^{2}$ $\mathrm{sec} / \mathrm{mrep} / \mathrm{hr}$ for Po-Be neutrons and $\mathrm{BF}_{3}$.

The neutron fluxes and $x$-ray dose rates were then determinable with a reasonable degree of confidence. That is, $\gamma$ and $\phi$ were obtained from the $\mathrm{CO}_{2}-\mathrm{BF}_{3}$ combination measurements and the calibration equations. Then, $\gamma$ and $\phi$ being known, the response of the tissue equivalent chamber could be predicted and compared with the observed total mrep/hr dose rate. Gross disagreements between the predicted and observed tissue equivalent dose rates indicated important departures of the stray radiation spectra from the calibration radiation spectra. It was found that most discrepancies between the predicted and observed tissue dose rates could be explained, at least qualitatively, by apparent differences between the energies of stray neutrons and of Po-Be neutrons. 


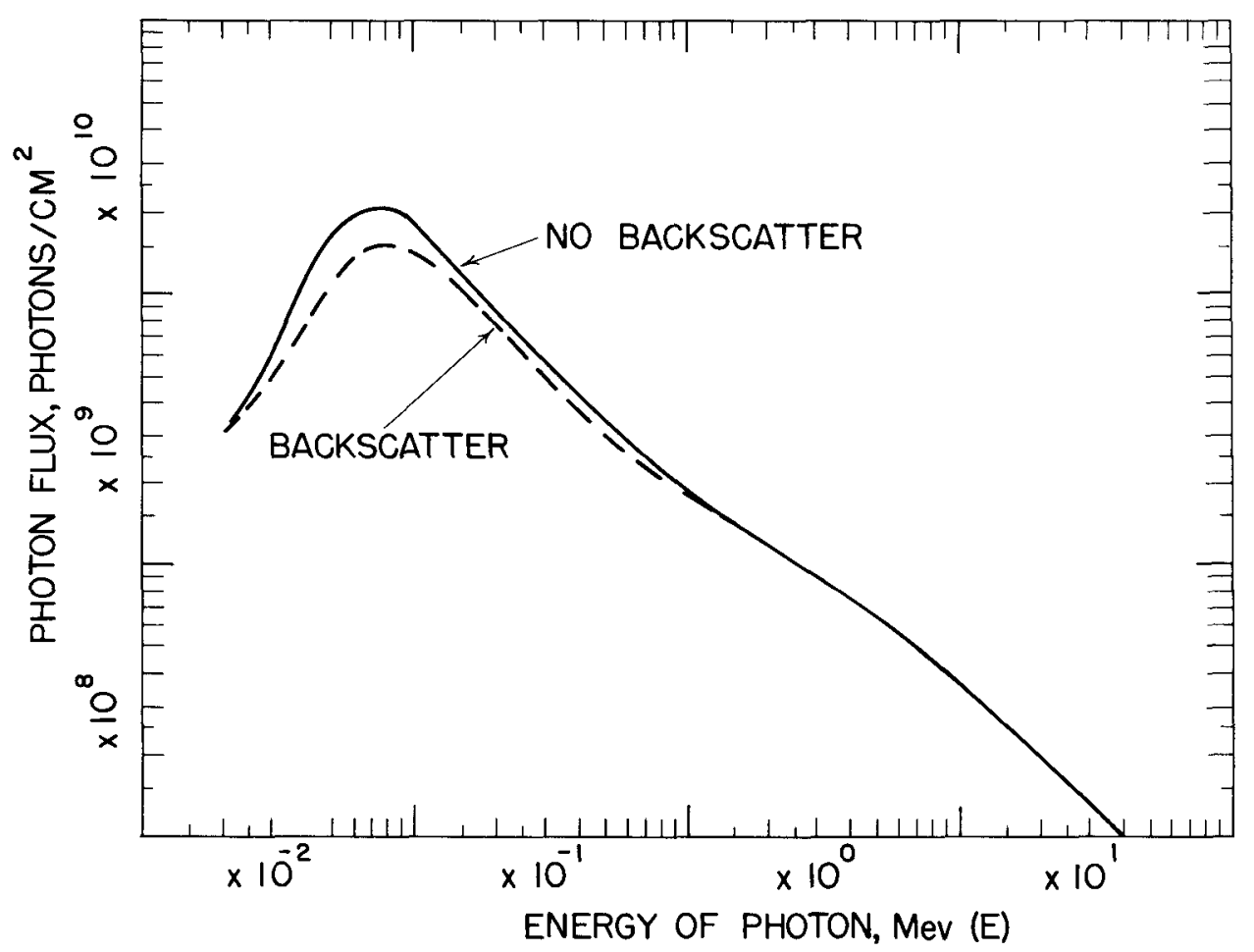

Fig. 4-Flux vs photon energy to produce $1 \mathrm{r}$ (inferred from reference 11, p. 138).

To supplement the ionization chambers, at least one fast neutron instrument and one purely thermal neutron detector have been found to be desirable. The Hurst fast neutron dosimeter and the Thompson fast-slow neutron survey meter have behaved admirably for this supplemental work at most accelerators. At a few accelerators where the predominant neutron energies were in the intermediate range, a version of the Hanson-McKibben long counter was also useful. However, it has received only limited use because of its weight and size.

All the scintillation and proportional counter instruments described below have been used at one or more of the pulsed machines that were surveyed. As expected these survey meters were limited by $x$-ray pile-up, in which $x$-ray pulses from the accelerator overrode the $x$-ray discriminator setting, and by interference from $r-f$ oscillations.

Instruments other than the ionization chambers that were used in the survey work were:

1. A version of the Hanson-McKibben long counter used in conjunction with a Nuclear Instrument and Chemical Corp., model 162, scaling unit.

2. A Radiation Counter Laboratory Mark II, model 2806, fast-slow neutron counter, AEC No. SPC-12A. This instrument, consisting of a $\mathrm{BF}_{3}$ counter and a polyethylene-lined argonfilled fast neutron energy flux counter, was developed at the University of California Radiation Laboratory by Thompson ${ }^{13}$ and has been described in the literature.

3. A ZnS-Lucite neutron scintillation counter, Nucleonic Company of America, model FN-1, AEC No. SBX-21A. This instrument (and a version of it using a 5-in.-diameter phosphor) was based on one developed at Brookhaven National Laboratory by Hornyak, Handloser, and Higinbotham. 14,15

4. A Nuclear Instrument and Chemical Corp. portable neutron survey meter (Nemo), model 2715, AEC No. SPC-10A, which employs two $\mathrm{BF}_{3}$ counters, one of which is enclosed in a wax block wrapped in cadmium.

5. A Radioactive Products, Inc., fast neutron dosimeter, model E-1, AEC No. SPC-6A, which employs a tissue equivalent proportional counter developed by Hurst. ${ }^{16}$

6. A Radiation Industries Company tissue equivalent radiation detector, model 1, AEC No. SPC-11A, which employs a Failla-Rossi tissue equivalent chamber. 
7. An Espey Company ionization chamber survey meter (Juno), AEC No. SIC-17C.

8. A Radioactive Products, Inc., ionization chamber survey meter (Samson), model D-5, AEC No. SIC-49B.

The above neutron and gamma-ray instruments were also appropriately calibrated with Po-Be or radium sources.

\section{PERSONNEL MONITORING RECORD}

The Brookhaven National Laboratory (BNL) off-site personnel monitoring service has been used at many of the accelerators surveyed by the HASL. Technical aspects of the BNL neutron film badge have been described by Cowan. ${ }^{17}$ Radiation exposures at the 15 accelerators surveyed in 1953 and 1954 were summarized in Report NYO-4699. Exposures occurring in 1955 and 1956 at some additional sites are presented in Table 3.

In both summaries it can be seen that roughly 10 to 25 per cent of the accelerator personnel accounted for about one-half the entries. It should be emphasized that the conclusion should not be drawn that this fraction (up to 25 per cent) of accelerator personnel are receiving serious continuing radiation doses, but rather that only a small minority of persons at each machine are responsible for accelerator operation and experimentation. Presumably these persons receive the greatest assistance from stray radiation surveys.

Most of the sites using the BNL film badge do so on a biweekly basis. However, in estimating the various fractions of the maximum permissible dose rate, the assumption was made that any radiation exposure was received within one week. This assumption should not be made when tabulating any individual's personnel monitoring record, but rather some correction would have to be made on the basis of a two-week maximum permissible dose. In any case, experience has indicated that accelerator personnel tend to accumulate radiation doses discontinuously.

Initially a measurement of 10 tracks per nuclear track film (i.e., per 25 microscope fields) was said to indicate a $40-\mathrm{hr}$ exposure to $20 \mathrm{Po}-\mathrm{Be} \mathrm{n} / \mathrm{cm}^{2}-\mathrm{sec}$, the maximum permissible fast neutron dose used by BNL at the inception of the off-site film badge service. It was pointed out that, where $30 \mathrm{n} / \mathrm{cm}^{2}-\mathrm{sec}$ was regarded as an appropriate limit for fast neutrons (equivalent to $300 \mathrm{mrem}$ in $40 \mathrm{hr}$ ), 15 tracks in 25 fields would be the proper number to use. ${ }^{17}$ The criterion used in Table 3 was 10 tracks/25 fields and, in fact, when HASL follows up unusual neutron exposures, the conservative value is used to correspond to the maximum permissible neutron level. The survey experience has tended to justify this conservatism.

The nuclear track film is practically insensitive to neutrons having energies below a few tenths Mev. Although the film does detect the most biologically hazardous neutrons, i.e., those having energies of a few Mev, the survey data have indicated that a large fraction of the stray neutron spectrum is often below the energy cutoff of the nuclear track film even at the highest energy accelerators. This point will be discussed further in Sec. 6.

\section{MAXIMUM PERMISSIBLE RADIATION DOSE}

A preliminary statement of the National Committee on Radiation Protection (NCRP) [Radiology, 68: 260 (1957)], which discusses the lowering of the maximum permissible accumulated dose, has been circulated recently for the guidance of the NCRP subcommittees that prepare the different detailed handbooks.

The statement summarizes the direction that maximum permissible occupational doses will almost certainly take in subsequent years, although the numerical values may be changed. It also distinguishes between permissible occupational dose and permissible dose to individuals in uncontrolled areas. The preliminary statement suggests that the yearly dose to the general public should not exceed $0.5 \mathrm{rem} / \mathrm{yr}$. It recommends in part that an individual's accumulated occupational dose should not exceed five times the number of years beyond age 18 expressed in roentgen equivalent man (rem), and no annual increment should exceed $15 \mathrm{rem}$. The weekly maximum permissible dose is still considered to be $0.3 \mathrm{rem}$, and the 13 -wk dose, $3 \mathrm{rem}$ when the weekly dose has been exceeded. These proposed recommendations are at present in a preliminary form and are still under discussion by the NCRP subcommittees in relation to their 
Table 3-SUMMARY OF FILM BADGE RECORDS

\begin{tabular}{|c|c|c|c|c|c|c|c|c|c|c|c|c|c|}
\hline \multirow[b]{2}{*}{ Installation } & \multirow{2}{*}{$\begin{array}{c}\text { Type of } \\
\text { accelerator }\end{array}$} & \multirow{2}{*}{$\begin{array}{c}\text { No. of } \\
\text { persons } \\
\text { wearing badges }\end{array}$} & \multirow[b]{2}{*}{ Dates } & \multicolumn{4}{|c|}{$\begin{array}{c}\text { Fast neutrons, } \\
\text { fraction weekly MPD }\end{array}$} & \multicolumn{5}{|c|}{$\begin{array}{l}\text { Gamma radiation, } \\
\text { fraction weekly MPD }\end{array}$} & \multirow[b]{2}{*}{ Remarks } \\
\hline & & & & $0.5-1.0$ & $1-2$ & $2-3$ & $>3$ & $0.25-0.50$ & $0.50-1.0$ & $1-2$ & $2-3$ & $>3$ & \\
\hline Yale University & $\begin{array}{l}1 \text { linear } \\
\text { accelerator } \\
1 \text { cyclotron }\end{array}$ & 23 & $\begin{array}{l}\text { Jan. } 10,1955- \\
\text { Jan. } 6,1957^{*}\end{array}$ & 13 & 1 & & & 3 & & & & & $\begin{array}{l}2 \text { persons } \\
\text { accounted } \\
\text { for } 46 \% \text { of } \\
\text { entries }\end{array}$ \\
\hline $\begin{array}{c}\text { Carnegie Institute } \\
\text { of Technology }\end{array}$ & Synchrocyclotron & 44 & $\begin{array}{l}\text { Jan. } 7,1955- \\
\text { Jan. } 3,1957 \dagger\end{array}$ & 54 & & & 1 & 164 & 85 & 47 & 8 & 3 & $\begin{array}{l}11 \text { persons } \\
\text { accounted } \\
\text { for } 45 \% \text { of } \\
\text { entries }\end{array}$ \\
\hline $\begin{array}{l}\text { Bartol Research } \\
\text { Foundation }\end{array}$ & $\begin{array}{l}2 \text { Van de Graaffs } \\
1 \text { Cockcroft- } \\
\text { Walton }\end{array}$ & 13 & $\begin{array}{l}\text { Jan. 3, 1955- } \\
\text { Dec. 30, 1956* }\end{array}$ & 9 & 3 & & & 6 & 2 & & & & $\begin{array}{l}1 \text { person } \\
\text { accounted } \\
\text { for } 45 \% \text { of } \\
\text { entries }\end{array}$ \\
\hline Stanford University & $\begin{array}{l}\text { Linear } \\
\text { accelerator }\end{array}$ & 96 & $\begin{array}{l}\text { Apr. 4, 1955- } \\
\text { Apr. 15, 1956* }\end{array}$ & 85 & 5 & & & 138 & 67 & 24 & 6 & 1 & $\begin{array}{l}10 \text { persons } \\
\text { accounted } \\
\text { for } 34 \% \text { of } \\
\text { entries }\end{array}$ \\
\hline $\begin{array}{l}\text { State University } \\
\text { of Iowa }\end{array}$ & $\begin{array}{l}1 \text { Van de Graaff } \\
1 \text { Cockcroft- } \\
\text { Walton }\end{array}$ & 30 & $\begin{array}{l}\text { Dec. } 31,1954- \\
\text { Jan. } 10,1957^{*}\end{array}$ & 14 & 2 & & & 1 & & 1 & & & $\begin{array}{l}\text { Entries } \\
\text { fairly } \\
\text { evenly } \\
\text { distributed }\end{array}$ \\
\hline $\begin{array}{l}\text { University of } \\
\text { Illinois }\end{array}$ & $\begin{array}{l}1 \text { cyclotron } \\
2 \text { betatrons }\end{array}$ & 16 & $\begin{array}{l}\text { Sept. 10, 1954- } \\
\text { Jan. 10, 1957* }\end{array}$ & 14 & & & & 34 & 15 & 5 & & 1 & $\begin{array}{l}4 \text { persons } \\
\text { accounted } \\
\text { for } 46 \% \text { of } \\
\text { entries }\end{array}$ \\
\hline
\end{tabular}

* Signifies a biweekly period.

$\dagger$ Signifies a weekly period. 
various existing reports (e.g., National Bureau of Standards Handbooks 55 and 59). However, the recommendations do indicate a trend toward a more conservative radiation exposure philosophy. Consequently, the question may arise concerning the practicality of the increased conservatism in terms of the existing protection at particle accelerator sites.

A scrutiny of the personnel monitoring records has indicated that few, if any, accelerator personnel exposure records approach the recommended maximum permissible accumulated dose. However, the limitations of personnel monitoring film badges, when used at existing and proposed high-energy accelerator sites, should be clearly understood. Specifically, it is emphasized that the film badge response, particularly the neutron film badge response, to very high energy radiations is not well known. Consequently, the accelerator operator should rely on survey instrumentation, as well as on personnel monitoring equipment, and to a large extent on the common sense rule-of-thumb of no unnecessary radiation exposures.

In view of this increased conservatism in radiation protection philosophy, coupled with the radiation instrument limitations, a word regarding accelerator shielding design is appropriate. The opinions of the authors appear in Sec. 7.

\section{INDIVIDUAL SURVEYS}

\subsection{Memorial Center for Cancer and Allied Diseases}

The measurements were made when this betatron produced $\mathrm{x}$ rays by bombarding a platinum target, located inside the "doughnut," with 22.5-Mev electrons. The survey was conducted during different beam orientations in the control room and in the corridor approaching the accelerator room proper. One reason for the additional measurements inside the vault was to attempt a determination of the importance of photoneutrons produced unintentionally in the betatron components. The only neutron detecting devices available for this study, other than the tissue equivalent ionization chamber, were the AEC No. SPC-6A fast neutron dosimeter and the AEC No. SBX-21A fast neutron scintillation counter. Both instruments were affected by $x$-ray pile-up in the exposed locations.

No neutrons were detected in the control room, although it was possible that low-energy neutrons were present, since both survey meters are insensitive to neutron energies below 0.2 to $0.4 \mathrm{Mev}$. Measurements made with NTA film indicated also that the neutron levels were low; however, as mentioned above, NTA film also cuts off at a few hundred kev. Results obtained with the tissue equivalent ionization chamber at the locations in Fig. 5 are shown in Table 4.

No special recommendations regarding the operation of the betatron were made on the basis of this survey. Radiation levels in the control room appeared to be well below the maximum permissible for continuous occupation.

\subsection{Yale University}

Stray radiation measurements were made during the early operation of the linear electron accelerator. A beam of electrons with energies of about $4 \mathrm{Mev}$ was produced by using no target at the end of the accelerator tube (i.e., only a Lucite cap to preserve the vacuum). This condition exists during the $r-f$ tune-up operation, which usually was performed by a person near location D (Fig. 6). Consequently, rough estimates of the electron energies and quantities in these locations were made. $\mathrm{X}$-radiation levels in the corridor and instrument room adjacent to the accelerator room during the bombardment of a gold target with the 4-Mev electrons were measured. Finally, stray radiation levels were examined during the intentional production of neutrons by the interaction of $x$ rays and beryllium. During this production of neutrons the electron energy was about $3 \mathrm{Mev}$, and the maximum neutron energy was about $1.3 \mathrm{Mev}$ since the photoneutron threshold ${ }^{4}$ for beryllium is about $1.7 \mathrm{Mev}$.

A crude estimate of the high-energy electron energy near location $D$ was made by performing absorption measurements with two ionization chamber survey meters, an SIC-49B (Samson) and the Yale SIC-11A (Beckman MX-2). The observed absorption curve for inhomogeneous electrons (beta-ray sources) can sometimes be approximated by an exponential function over a large portion of the electron range. ${ }^{18}$ That is, when the observed data appear 


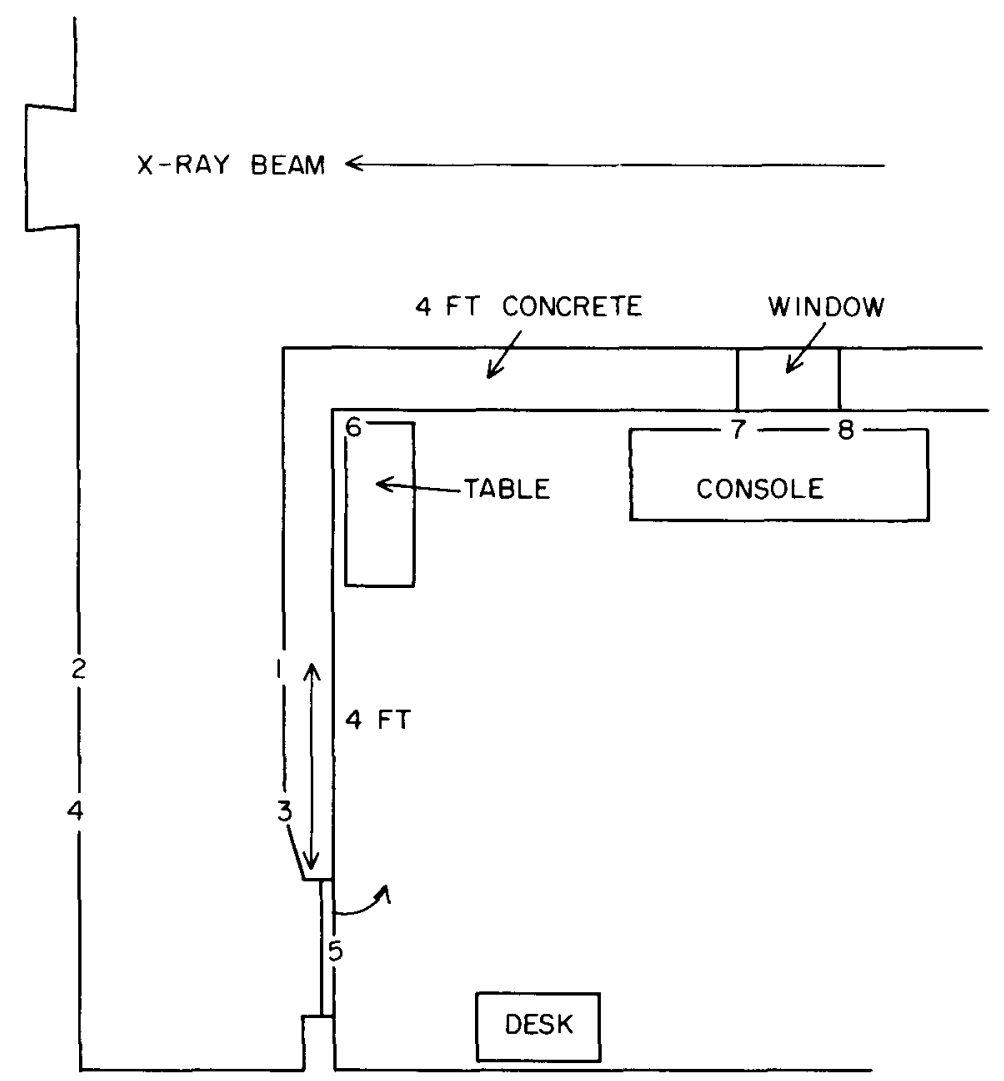

Fig. 5-Memorial Center for Cancer and Allied Diseases 22.5-Mev betatron layout, Dec. 21, 1954 (not to scale).

Table 4-STRAY RADIATION MEASUREMENTS AT 22.5-MEV BETATRON (DEC. 21, 1954) (Beam Monitor $=100 \mathrm{r} / \mathrm{min}$ )

\begin{tabular}{|c|c|c|c|c|c|}
\hline Position & $\begin{array}{c}\text { Beam } \\
\text { orientation }\end{array}$ & $\begin{array}{l}\text { Radiation } \\
\text { level }\end{array}$ & Position & $\begin{array}{c}\text { Beam } \\
\text { orientation }\end{array}$ & $\begin{array}{l}\text { Radiation } \\
\text { level }\end{array}$ \\
\hline 3 & \multirow[t]{5}{*}{ Horizontal } & $10 \mathrm{mrep} / \mathrm{hr}$ & 1 & \multirow[t]{5}{*}{45 degree } & $4 \mathrm{mrep} / \mathrm{hr}$ \\
\hline 5 & & $\begin{array}{l}0.65 \mathrm{mrep} / \mathrm{hr} \\
\sim 0.1^{*} \mathrm{mrep} / \mathrm{hr}\end{array}$ & 2 & & $\begin{array}{l}10 \mathrm{mrep} / \mathrm{hr} \\
15 \mathrm{mr} / \mathrm{hr} \dagger\end{array}$ \\
\hline 6 & & $0.15 \mathrm{mrep} / \mathrm{hr}$ & 5 & & $0.37 \mathrm{mrep} / \mathrm{hr}$ \\
\hline 7 & & $0.65 \mathrm{mrep} / \mathrm{hr}$ & & & Nothing detected* \\
\hline 8 & & $0.05 \mathrm{mrep} / \mathrm{hr}$ & 7 & & $0.24 \mathrm{mrep} / \mathrm{hr}$ \\
\hline 5 & \multirow[t]{4}{*}{ Vertical } & $0.37 \mathrm{mrep} / \mathrm{hr}$ & 1 & \multirow[t]{4}{*}{ Diagonal } & \multirow[t]{4}{*}{$12 \mathrm{mrep} / \mathrm{hr}$} \\
\hline 7 & & $0.13 \mathrm{mrep} / \mathrm{hr}$ & & & \\
\hline & & Nothing detected* & & & \\
\hline 8 & & $0.02 \mathrm{mrep} / \mathrm{hr}$ & & & \\
\hline
\end{tabular}

* Fast neutron dosimeter, SPC-6A.

†An SIC - $17 \mathrm{C}$ read $24 \mathrm{mr} / \mathrm{hr}$ with the thin rubber hydrochloride window and $15 \mathrm{mr} / \mathrm{hr}$ with the $3 / 32$-in. aluminum shield. 


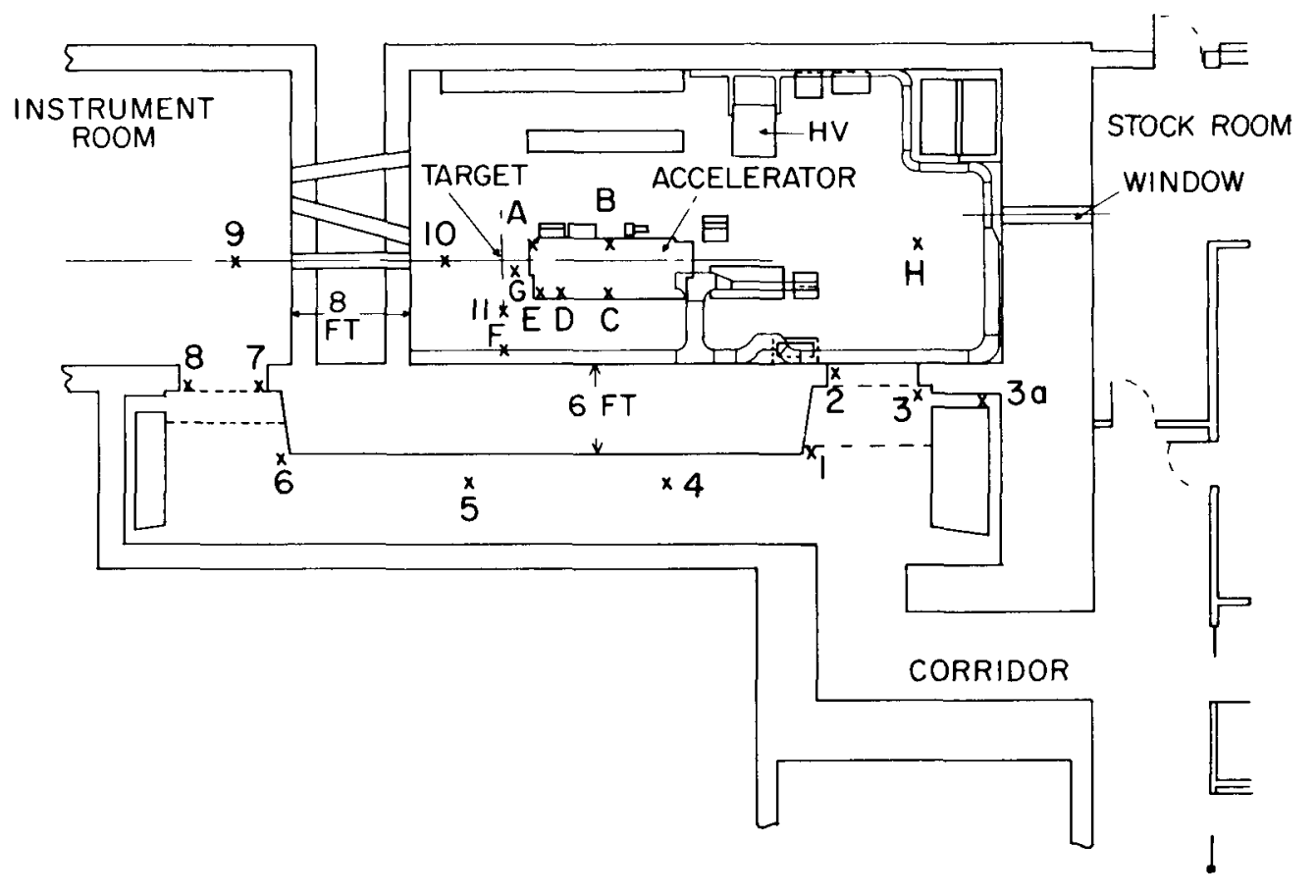

Fig. 6-Yale University linear accelerator layout, January 1955 (not to exact scale).

as a straight line on semilogarithmic graph paper, the electron level behind an absorber thickness $x$ is $I=I_{0} e^{-\mu x}$, where $\mu$ is the absorption coefficient in $\mathrm{cm}^{-1}$ (Fig. 7). The maximum energy in Mev in terms of half-value thickness $d$ is $0.693 \alpha=0.032 \mathrm{E} \mathrm{m}^{1.33}=\mathrm{d}$, where $\alpha$ is the mass-absorption coefficient.

Absorption measurements in vinyl sheets made with the Beckman MX-2 yielded a value of $\mathrm{d}=95 \mathrm{mg} / \mathrm{cm}^{2}$ and consequently $\mathrm{E}_{\mathrm{m}}=2.3 \mathrm{Mev}$. Similarly, measurements made with the Samson gave $\mathrm{d}=177 \mathrm{mg} / \mathrm{cm}^{2}$ and $\mathrm{E}_{\mathrm{m}}=2.6 \mathrm{Mev}$.

It was noted that absorption measurements performed near location $\mathrm{H}$ indicated that the stray radiation was principally electromagnetic in nature.

The method was tested by obtaining similar measurements with the UX II betas $(2.3 \mathrm{Mev})$ from normal uranium as the radiation source. Estimates of $E_{m}$ were $1.8 \mathrm{Mev}$ for the Samson and $2.3 \mathrm{Mev}$ for the Beckman MX-2 measurements. It was thought that a crude estimate of the dose rate due to high-speed electrons might be made by comparing the survey data and the UX II data, if the energies were comparable and if the decrease of UX II beta-ray intensity was due only to the vinyl absorbers. The surface beta dose rate from normal uranium has been found ${ }^{10}$ to be $240 \mathrm{mrep} / \mathrm{hr}$. Thus the electron dose rate would be approximated by multiplying 240 $\mathrm{mrep} / \mathrm{hr}$ by a correction factor, the ratio of the zero absorber electron reading to the zero absorber UX II beta reading, depending on the particular survey meter. The electron dose rate at location $D$ was estimated to be about $12 \mathrm{mrep} / \mathrm{hr}$. Refinements of the technique are being considered to enhance its usefulness at electron accelerators.

$X$-ray measurements were attempted inside the accelerator vault, with the gold target in place, with 200-mr pocket dosimeters and film badges. The $x$-ray levels ranged from about $1 \mathrm{r} / \mathrm{hr}$ at the low end of the machine to about $150 \mathrm{r} / \mathrm{hr}$ at the head of the accelerator near location A. X-ray measurements made in the corridor and instrument room are summarized in Table 5. Radiation levels encountered during neutron production appear in Table 6.

Except near the vault doorways and the beam port, the radiation levels were insignificant. Measurements were made in the more exposed locations because the doors were often left open during the early days of the Yale machine when it was frequently started and shut down. 


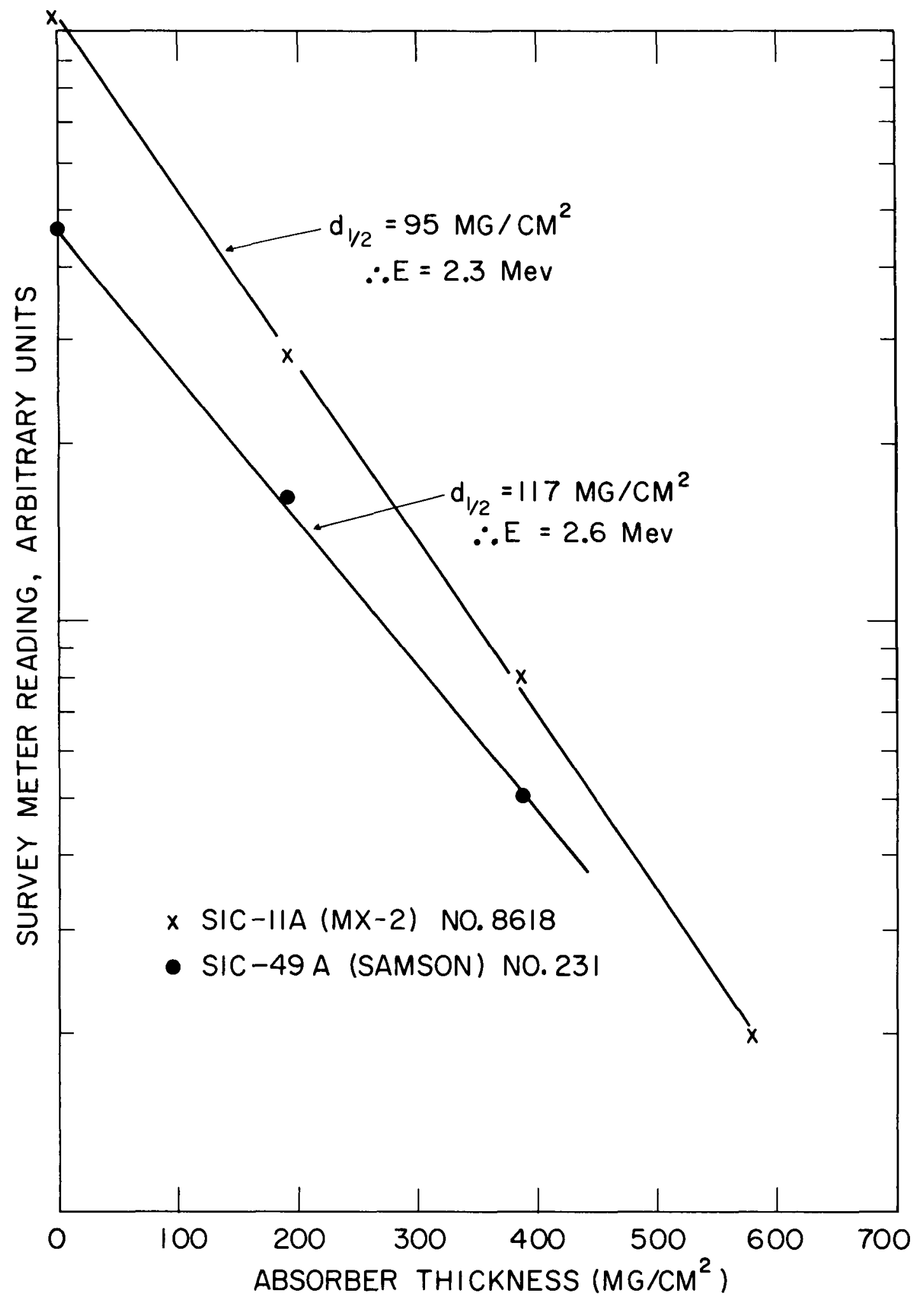

Fig. 7-Electron absorption measurements at Yale University linear accelerator, January 1955. 
Table 5-X-RADIATION LEVELS AT YALE UNIVERSITY

LINEAR ACCELERATOR (JAN. 13, 1955)

(3-Mev Electrons on Gold; Peak Current $\cong 20 \mathrm{ma}$; Vault Door Open Halfway)

\begin{tabular}{|c|c|c|}
\hline Location & Instrument* & Radiation \\
\hline 2 & SIC-17C & $\begin{array}{l}6 \mathrm{mrep} / \mathrm{hr}(3 / 32-\text { in. } \mathrm{Al}) \\
16 \mathrm{mrep} / \mathrm{hr}\end{array}$ \\
\hline & PTE chamber & $2-3 \mathrm{mrep} / \mathrm{hr}$ \\
\hline $1-2$ & TE chamber & $0.9 \mathrm{mrep} / \mathrm{hr}$ \\
\hline 1 & $\begin{array}{l}\text { SIC }-17 \mathrm{C} \\
\mathrm{TE} \text { chamber }\end{array}$ & $\begin{array}{l}\text { Nothing detected } \\
0.2-0.4 \mathrm{mrep} / \mathrm{hr}\end{array}$ \\
\hline 3 & $\begin{array}{l}\text { TE chamber } \\
\text { PTE chamber }\end{array}$ & $\begin{array}{l}\sim 3 \mathrm{mrep} / \mathrm{hr} \\
\sim 3 \mathrm{mrep} / \mathrm{hr}\end{array}$ \\
\hline 2 (beam unsteady) & SIC-17C & $\begin{array}{l}10 \mathrm{mrep} / \mathrm{hr}\left({ }^{3} / 32-\mathrm{in} . \mathrm{Al}\right) \\
40-45 \text { (open window) }\end{array}$ \\
\hline 3 & $\begin{array}{l}\text { TE chamber } \\
\text { PTE chamber } \\
\text { SIC-17C }\end{array}$ & $\begin{array}{l}8.8 \mathrm{mrep} / \mathrm{hr} \\
8.0 \mathrm{mrep} / \mathrm{hr} \\
8 \mathrm{mrep} / \mathrm{hr}(3 / 32-\mathrm{in} . \mathrm{Al})\end{array}$ \\
\hline $\begin{array}{l}4(9.5 \mathrm{ft} \text { from } \\
\text { corner) }\end{array}$ & $\begin{array}{l}\text { TE chamber } \\
\text { SIC }-17 \mathrm{C}\end{array}$ & $\begin{array}{l}0.01 \mathrm{mrep} / \mathrm{hr} \\
\text { Nothing detected }\end{array}$ \\
\hline $\begin{array}{l}5(21 \mathrm{ft} \text { from } \\
\text { corner })\end{array}$ & $\begin{array}{l}\text { TE chamber } \\
\text { PTE chamber }\end{array}$ & $\begin{array}{l}\text { Nothing detected } \\
\text { Nothing detected }\end{array}$ \\
\hline 6 & $\begin{array}{l}\text { TE chamber } \\
\text { SIC }-17 \mathrm{C}\end{array}$ & $\begin{array}{l}0.04 \mathrm{mrep} / \mathrm{hr} \\
\text { Nothing detected }\end{array}$ \\
\hline 7 & $\begin{array}{l}\text { TE chamber } \\
\text { SIC }-17 \mathrm{C}\end{array}$ & $\begin{array}{l}0.22 \mathrm{mrep} / \mathrm{hr} \\
\sim 2 \mathrm{mrep} / \mathrm{hr} \text { (open window) } \\
\text { Nothing detected }(3 / 32-\mathrm{in} . \mathrm{Al} \text { ) }\end{array}$ \\
\hline 8 & TE chamber & $0.28 \mathrm{mrep} / \mathrm{hr}$ \\
\hline $\begin{array}{l}9(100 \mathrm{~cm} \text { from } \\
\text { radiation port })\end{array}$ & $\begin{array}{l}\text { TE chamber } \\
\text { SIC }-17 C\end{array}$ & $\begin{array}{l}3.52 \mathrm{rep} / \mathrm{hr} \\
\text { Off scale }\end{array}$ \\
\hline $\begin{array}{l}10(100 \mathrm{~cm} \text { from } \\
\text { target) }\end{array}$ & TE chamber & $104 \mathrm{rep} / \mathrm{hr}$ \\
\hline
\end{tabular}

Table 6-RADIATION LEVELS DURING PRODUCTION OF 1.3-MEV NEUTRONS BY $(\gamma, n)$ IN GOLD AT YALE UNIVERSITY LINEAR ACCELERATOR (JAN. 13, 1955)

(3-Mev Electrons on Gold; Peak Current $\cong 20$ ma; Vault Door Open Halfway)

\begin{tabular}{lll}
\multicolumn{1}{c}{ Location } & \multicolumn{1}{c}{ Instrument } & \multicolumn{1}{c}{ Radiation } \\
\hline $10(100 \mathrm{~cm}$ from target) & TE chamber & $75.7 \mathrm{rep} / \mathrm{hr}$ \\
$11\left(100 \mathrm{~cm}\right.$ at $\left.90^{\circ}\right)$ & TE chamber & $66.2 \mathrm{rep} / \mathrm{hr}$ \\
1 & PTE chamber & $10 \mathrm{mrep} / \mathrm{hr}$ \\
1 a (behind door) & PTE chamber & $2.0 \mathrm{mrep} / \mathrm{hr}$ \\
1 (no beryllium, & PTE chamber & $14 \mathrm{mrep} / \mathrm{hr}$ \\
1.e., no intentional & & \\
neutrons) & & \\
5 & All neutron and & Nothing detected \\
9 & gamma instruments & \\
& TE chamber & $33 \mathrm{rep} / \mathrm{hr}$ \\
& SIC-17C & $3 \mathrm{rep} / \mathrm{hr}(\mathrm{open} \mathrm{window})$ \\
7 & & $4 \mathrm{rep} / \mathrm{hr}(3 / 32-\mathrm{in}$. Al) \\
& PTE chamber & $0.14 \mathrm{mrep} / \mathrm{hr}$ \\
& FND* & $\sim 0.1 \mathrm{mrep} / \mathrm{hr}$ \\
& SIC-17C & Nothing detected \\
& PTE chamber & $0.83 \mathrm{mrep} / \mathrm{hr}$ \\
& FND & $0.40 \mathrm{mrep} / \mathrm{hr}$ \\
& SIC-17C & Nothing detected \\
\hline
\end{tabular}

*FND, fast neutron dosimeter.

* PTE, portable tissue equivalent ionization chamber; TE, tissue equivalent chamber with vibrating-reed electrometer. 
Also, the instrument room was occasionally in use during accelerator operation. The dose rate in the beam was very high, and, consequently, the following recommendations were made

1 It was recommended that the shielding doors leading to the instrument and accelerator rooms should always be closed when the accelerator is in operation

2. It was recommended that a positive barrier be located in the corridor leading from the control room to the accelerator room, possibly adjacent to the large radiation sign painted on the wall. This barrier could be an electric eye or other device interlocked with the accelerator operation.

3. It was recommended that anyone in the accelerator room during accelerator operation should have avallable an ionization chamber survey meter such as the SIC-11A (Beckman MX2). When this survey meter is used for detecting electrons, the thin rubber hydrochloride window should not be shielded with the Bakelite (gamma-ray) shield This is not meant to supplant in any way the two prior recommendations, but it simply refers to survey meter protection during exceptional circumstances when it is necessary to be in the accelerator room at low beam currents for tune-up purposes.

4. It was recommended that the Yale University linear electron accelerator group aval itself of a neutron film badge personnel monitoring service. Although the contribution of the neutrons to total radiation dose appears to be small, the uncertainty of neutron dosimetry suggests the use of a neutron personnel monitoring system.

\section{Carnegie Institute of Technology}

The radiation survey performed at Carnegie Institute of Technology (CIT) in February 1955 was intended to test the efficacy of shielding installed after the previous series of measurements. Specifically, the sections of shielding labeled $380 \mathrm{lb} / \mathrm{ft}^{3}$ (Fig. 8) were new A second reason for the survey was to determine the cause of intermittent, but fairly high, gammaradiation exposures where detected by the BNL film badge.

Measurements were obtained during three modes of synchrocyclotron operation

1. Reverse field, $1 / 2-$ by $1 / 4-$ by $1 / 4-1 n$. copper target (see Table 7 )

2. Normal field, no target (see Table 8)

3. Normal field, $1 / 2$ - by $1 / 4$ - by $2-$ in. beryllium target (see Table 9 )

A measurement of the $\mathrm{x}$ rays inside the synchrocyclotron vault near the target area (location $\mathrm{C}$ in Fig. 8) indicated that the level was about $08 \mathrm{r} / \mathrm{hr}$ about $5 \mathrm{hr}$ after shutdown.

The tabulated data include estimates of the fractions of the maximum permissible neutron level in the various locations. Because of inadequate knowledge of the stray neutron energy spectrum, the following criterion was used in presenting this survey data and some of the subsequent data.

Natıonal Bureau of Standards (NBS) Handbook 59 (reference 20), which serves as a basic guide in radiation protection, states that.

For adults under 45 years of age whose entire body, or major portion thereof, is exposed to ionizing radiation from external sources for an indefinite period of years, the maximum permissible total weekly doses shall be $300 \mathrm{mrem}$ in the blood-forming organs, the gonads, and the lenses of the eyes, 600 mrem in the skin, and the respective values of the weekly doses in millirems in all other organs and tissues of the body according to the basic permissible dose distribution

NBS Handbook 55 has suggested a maximum permissible fast neutron flux density of $30 \mathrm{n} / \mathrm{cm}^{2}$ sec. (BNL uses $20 \mathrm{n} / \mathrm{cm}^{2}-\mathrm{sec}$ for $40 \mathrm{hr}$ as the maximum permissible flux density in the film badge program.) Fast neutrons are believed to have a relative biological effectiveness of about 10 , therefore the maximum permissible fast neutron weekly dose $1530 \mathrm{mrep}$. Substantial uncertainties exist in neutron dosimetry in both the measuring techniques and the knowledge of biological effects. Therefore, a safety factor of 2 was introduced to compensate for the spectral and instrumental deficiencies of currently avallable fast neutron instruments. The measured quantity taken to correspond to the maximum permissible exposure (MPE) rates was then 0.375 $\mathrm{mrep} / \mathrm{hr}$, or $15 \mathrm{n} / \mathrm{cm}^{2}-\mathrm{sec}$, for a $40-\mathrm{hr}$ work week. The maximum permissible thermal neutron flux density is $2000 \mathrm{n}_{\mathrm{t}} / \mathrm{cm}^{2}$-sec.

The general stray radiation levels in the experimental and equipment rooms were substantially below those encountered during the previous surveys for similar modes of operation. 


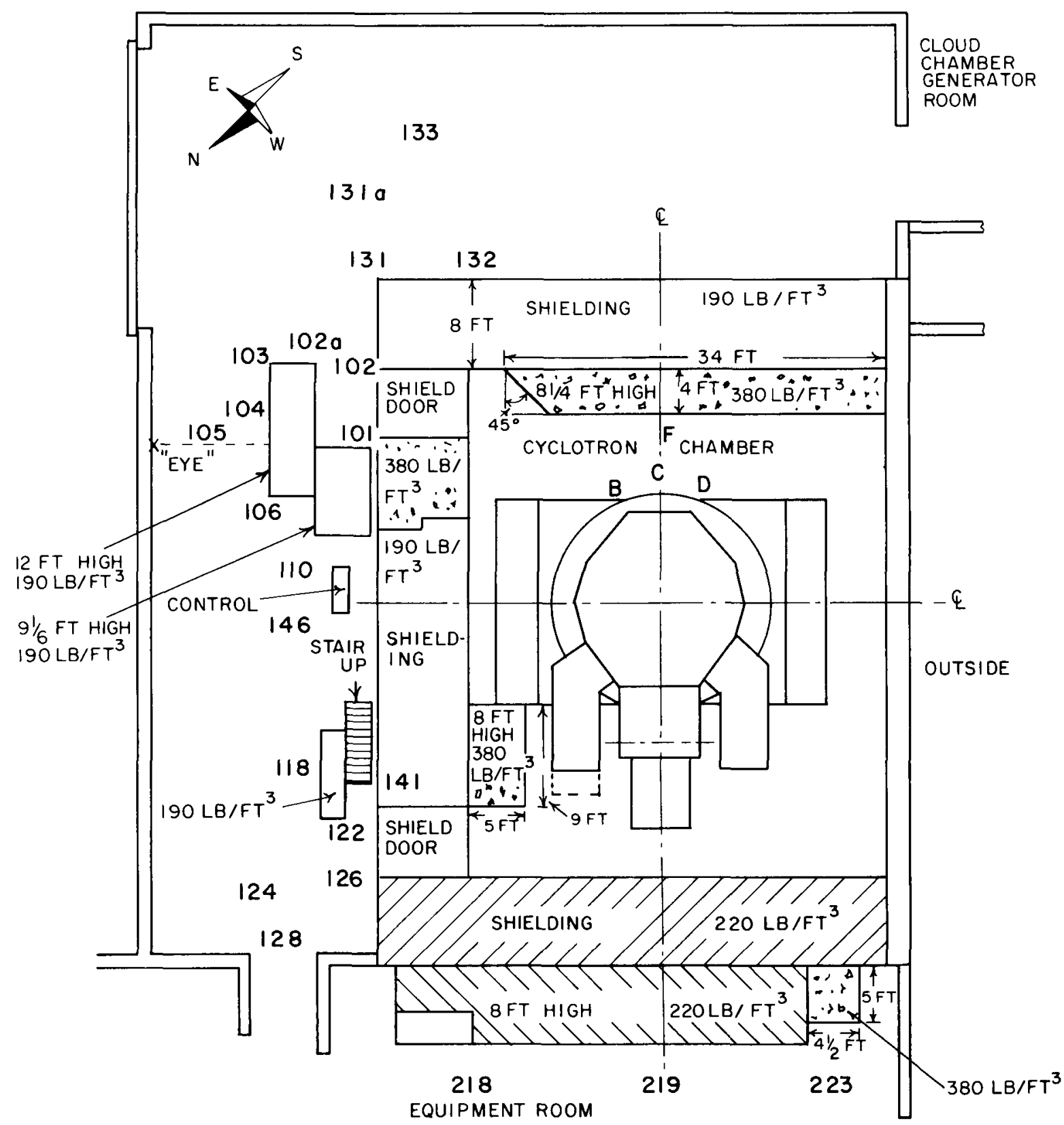

Fig. 8-Carnegie Institute of Technology NRC synchrocyclotron layout, February 1955.

With only a few exceptions, all locations in accessible places experienced levels less than the fast neutron MPE rate $\left(0.375 \mathrm{mrep} / \mathrm{hr}\right.$, or $\left.15 \mathrm{n}_{\mathrm{f}} / \mathrm{cm}^{2}-\mathrm{sec}\right)$. The exceptions encountered were:

1. Atop the cyclotron vault which, although not a normal work area, is not physically separated from the experimental room by a positive barrier.

2. The area in front of the first vault door (location 126).

3. The locations opposite the "thin" shield in the equipment room (near location 223).

4. The unregulated outside areas near the rectifier house.

It was emphasized that any appreciable augmentation of the beam current could result in the excessive radiation levels previously encountered.

It was further pointed out that the measurements reported refer only to thermal and fast neutrons ( 1 to $20 \mathrm{Mev}$ ). The contribution to the total level by the very fast components (greater 
than $20 \mathrm{Mev}$ ) is not definitely known; therefore, it was believed that, for occupied areas near high-energy accelerators, the stray radiation levels should not exceed 25 per cent of the maximum permissible weekly dose rate, $300 \mathrm{mrem} /$ wk as measured.

The discrepancy between the fast neutron dosimeter and the $\mathrm{ZnS}$-Lucite detector values was later attributed to an apparent decrease in the dosimeter sensitivity.

The recommendation was made that operations inside the vault during shutdown should be performed so that any one person, who also is subject to stray radiation when the machine is in operation, shall not receive more than 25 per cent of the maximum permissible dose (MPD) of gamma radiation in any given week (i.e., $75 \mathrm{mrem}$ ).

It was recommended that the areas in the vicinity of the first vault door (location 126) and on top of the shield be posted with appropriate radiation signs when the stray neutron levels exceed $0.4 \mathrm{mrep} / \mathrm{hr}$ during extended periods of operation as determined by a fast neutron dosimeter. It is suggested that the posting of these signs be routinely carried out by the cyclotron operator during certain modes of operation to be specified by the local health physicist.

It was recommended that the area in the vicinity of the northwest end of the rectifier house and the water tower be restricted and designated with suitable radiation signs.

No special recommendations or suggestions were warranted with regard to the equipment room, which appears very adequately shielded for the three modes employed during this survey, except to mention that fairly high radiation levels can be encountered in the inaccessible areas near the centrifuge.

It was emphasized that the area to the southwest of the cyclotron, near the radiation beam ports, should still be regarded as an exclusion area during cyclotron operation by means of the continued use of the electric eye.

Table 7 -SURVEY OF CIT-NRC SYNCHROCYCLOTRON (FEB. 3, 1955)

\begin{tabular}{|c|c|c|c|}
\hline Location & Instrument & Radiation level & $\begin{array}{c}\text { Fraction } \\
\text { of MPD } \\
\text { (neutrons) }\end{array}$ \\
\hline $\begin{array}{c}\text { 103a (no beam, } \\
\text { magnet on) }\end{array}$ & $\mathrm{TE}$ chamber & No appa rent effect & \\
\hline \multirow[t]{2}{*}{$103 a$} & FND & Nothing detected & 0 \\
\hline & $\mathrm{ZnS*}$ & Occasional count & \\
\hline \multirow[t]{2}{*}{$131 \mathrm{a}$} & FND & $0.36 \mathrm{mrep} / \mathrm{hr}$ & \\
\hline & $\mathrm{ZnS}$ & $43 \mathrm{n}_{\mathrm{f}} / \mathrm{cm}^{2}-\mathrm{sec}$ & 2.9 \\
\hline \multirow[t]{2}{*}{$131 \mathrm{a}$} & TE chamber & $0.85 \mathrm{~m} \mathrm{rep} / \mathrm{hr}$ & \\
\hline & FND & $1.06 \mathrm{mrep} / \mathrm{hr}$ & 2.8 \\
\hline 131a (beam up) & TE chamber & $1.10 \mathrm{mrep} / \mathrm{hr}$ & 2.9 \\
\hline $\begin{array}{l}132(10 \mathrm{ft} \text { from } \\
131)\end{array}$ & $\mathrm{ZnS}$ & $69 \mathrm{n}_{\mathrm{f}} / \mathrm{cm}^{2}-\mathrm{sec}$ & 4.6 \\
\hline 133 & $\mathrm{ZnS}$ & $43 \mathrm{n}_{\mathrm{f}} / \mathrm{cm}^{2}-\mathrm{sec}$ & 2.9 \\
\hline 102 & $\mathrm{ZnS}$ & $12 \mathrm{n}_{\mathrm{f}} / \mathrm{cm}^{2}-\mathrm{sec}$ & 0.8 \\
\hline 101 & $\mathrm{ZnS}$ & $10 \mathrm{n}_{\mathrm{f}} / \mathrm{cm}^{2}-\mathrm{sec}$ & 0.7 \\
\hline \multirow[t]{2}{*}{104} & FND & $<0.1 \mathrm{mrep} / \mathrm{hr}$ & $<0.3$ \\
\hline & $\mathrm{ZnS}$ & Occasional count & \\
\hline \multirow[t]{3}{*}{110} & TE chamber & $0.15 \mathrm{mrep} / \mathrm{hr}$ & \\
\hline & FND & $<0.1 \mathrm{mrep} / \mathrm{hr}$ & \\
\hline & $\mathrm{ZnS}$ & $\sim 8 \mathrm{n}_{\mathrm{f}} / \mathrm{cm}^{2}-\mathrm{sec}$ & 0.5 \\
\hline \multirow[t]{3}{*}{126} & TE chamber & $1.19 \mathrm{mrep} / \mathrm{hr}$ & \\
\hline & FND & $0.79 \mathrm{mrep} / \mathrm{hr}$ & 2.1 \\
\hline & $\mathrm{ZnS}$ & $64 \mathrm{n}_{\mathrm{f}} / \mathrm{cm}^{2}-\mathrm{sec}$ & 4.3 \\
\hline 126 (beam down) & FND & $0.70 \mathrm{mrep} / \mathrm{hr}$ & 1.9 \\
\hline \multirow[t]{2}{*}{141} & $\mathrm{ZnS}$ & $117 \mathrm{n}_{\mathrm{f}} / \mathrm{cm}^{2}-\mathrm{sec}$ & 7.8 \\
\hline & FND & $5.4 \mathrm{mrep} / \mathrm{hr}$ & 14 \\
\hline $\begin{array}{l}\text { Equipment room } \\
\text { (general) }\end{array}$ & $\mathrm{ZnS}$ & Occasional count & \\
\hline
\end{tabular}

* ZnS, ZnS-Lucite scintillation counter. 
Table 8-SURVEY OF CIT-NRC SYNCHROCYCLOTRON (FEB. 3, 1955) (Normal Field, No Target)

\begin{tabular}{|c|c|c|c|}
\hline Location & Instrument* & Radiation level & $\begin{array}{c}\text { Fraction } \\
\text { of MPD } \\
\text { (neutrons) }\end{array}$ \\
\hline \multirow[t]{2}{*}{101} & FND & $6.1 \mathrm{mrep} / \mathrm{hr}$ & 16 \\
\hline & $\mathrm{ZnS}$ & $540 \mathrm{n}_{\mathrm{f}} / \mathrm{cm}^{2}-\mathrm{sec}$ & 36 \\
\hline \multirow[t]{2}{*}{102} & FND & $6.1 \mathrm{mrep} / \mathrm{hr}$ & 16 \\
\hline & $\mathrm{ZnS}$ & $440 \mathrm{n}_{\mathrm{f}} / \mathrm{cm}^{2}-\mathrm{sec}$ & 29 \\
\hline \multirow[t]{2}{*}{$102 a$} & FND & $3.1 \mathrm{mrep} / \mathrm{hr}$ & 8.3 \\
\hline & $\mathrm{ZnS}$ & $250 \mathrm{n}_{\mathrm{f}} / \mathrm{cm}^{2}-\mathrm{sec}$ & 17 \\
\hline \multirow[t]{3}{*}{131} & TE chamber & $0.28 \mathrm{mrep} / \mathrm{hr}$ & \\
\hline & FND & $0.4 \mathrm{mrep} / \mathrm{hr}$ & 1.1 \\
\hline & $\mathrm{ZnS}$ & $\sim 10 \mathrm{n}_{\mathrm{f}} / \mathrm{cm}^{2}-\mathrm{sec}$ & $\sim 0.7$ \\
\hline $\begin{array}{l}\text { Experimental } \\
\quad \text { area }\end{array}$ & $\mathrm{ZnS}$ & $\begin{array}{l}\text { Up to } \sim 20 \mathrm{n}_{\mathrm{f}} / \mathrm{cm}^{2}-\mathrm{sec} \\
\text { at about center line, } \\
\text { shield ports closed }\end{array}$ & \\
\hline \multirow{3}{*}{$103 a$} & TE chamber & $1.9 \mathrm{mrep} / \mathrm{hr}$ & \\
\hline & FND & $1.2 \mathrm{mrep} / \mathrm{hr}$ & 3.2 \\
\hline & $\mathrm{ZnS}$ & $51 \mathrm{n}_{f} / \mathrm{cm}^{2}-\mathrm{sec}$ & 3.4 \\
\hline 105 & TE chamber & $0.33 \mathrm{mrep} / \mathrm{hr}$ & \\
\hline \multirow[t]{2}{*}{110} & TE chamber & $0.10 \mathrm{mrep} / \mathrm{hr}$ & \\
\hline & FND & $<0.10 \mathrm{mrep} / \mathrm{hr}$ & $<0.3$ \\
\hline \multirow[t]{2}{*}{146} & FND & $<0.10 \mathrm{mrep} / \mathrm{hr}$ & $<0.3$ \\
\hline & $\mathbf{Z n S}$ & Nothing detected & 0 \\
\hline \multirow[t]{2}{*}{141} & FND & $0.85 \mathrm{mrep} / \mathrm{hr}$ & 2.3 \\
\hline & $\mathrm{BF}_{3}$ & $11 \mathrm{n}_{\mathrm{t}} / \mathrm{cm}^{2}-\mathrm{sec}$ & $\sim 0.01$ \\
\hline \multirow[t]{3}{*}{126} & TE chamber & $0.15 \mathrm{mrep} / \mathrm{hr}$ & \\
\hline & FND & $<0.1 \mathrm{mrep} / \mathrm{hr}$ & $<0.3$ \\
\hline & $\mathrm{ZnS}$ & Occasional count & \\
\hline \multirow[t]{3}{*}{128} & TE chamber & $0.08 \mathrm{mrep} / \mathrm{hr}$ & \\
\hline & FND & $<0.1 \mathrm{mrep} / \mathrm{hr}$ & $<0.3$ \\
\hline & $\mathrm{ZnS}$ & Occasional count & \\
\hline \multirow[t]{3}{*}{218} & TE chamber & $0.12 \mathrm{mrep} / \mathrm{hr}$ & \\
\hline & FND & $<0.1 \mathrm{mrep} / \mathrm{hr}$ & $<0.3$ \\
\hline & $\mathrm{ZnS}$ & Occasional count & \\
\hline \multirow[t]{2}{*}{219} & FND & $<0.1 \mathrm{mrep} / \mathrm{hr}$ & $<0.3$ \\
\hline & $\mathrm{ZnS}$ & Occasional count & \\
\hline \multirow[t]{2}{*}{223} & TE chamber & $0.21 \mathrm{mrep} / \mathrm{hr}$ & \\
\hline & $\mathrm{ZnS}$ & $\sim 10 \mathrm{n}_{\mathrm{f}} / \mathrm{cm}^{2}-\mathrm{sec}$ & $\sim 0.7$ \\
\hline Equipment room & $\mathrm{ZnS}$ & $\sim 10 \mathrm{n}_{\mathrm{f}} / \mathrm{cm}^{2}-\mathrm{sec}$ & $\sim 0.7$ \\
\hline $\begin{array}{l}\text { Work bench* near } \\
\text { rear door }\end{array}$ & $\mathbf{B F}_{3}$ & $\sim 5 \mathrm{n}_{\mathrm{t}} / \mathrm{cm}^{2}-\mathrm{sec}$ & \\
\hline $\begin{array}{l}\text { Southeast end } \\
\text { of rectifier house }\end{array}$ & $\mathrm{ZnS}$ & Occasional count & \\
\hline $\begin{array}{l}\text { Between water tower } \\
\text { and rectifier house }\end{array}$ & $\mathrm{ZnS}$ & $117 \mathrm{n}_{\mathrm{f}} / \mathrm{cm}^{2}-\mathrm{sec}$ & 7.8 \\
\hline $\begin{array}{l}\text { Atop steel } \\
\text { retaining wall, } \\
\text { NW end rectifier } \\
\text { house }\end{array}$ & FND & $\begin{array}{l}30 \mathrm{mrep} / \mathrm{hr} \\
\text { off scale } \\
\left(>700 \mathrm{n}_{\mathrm{f}} / \mathrm{cm}^{2}-\mathrm{sec}\right)\end{array}$ & 80 \\
\hline $\begin{array}{l}\text { Mound between } \\
\text { cyclotron and } \\
\text { garage }\end{array}$ & $\mathrm{ZnS}$ & Occasional count & \\
\hline
\end{tabular}

* Other areas of equipment room when scanned on this date with the $\mathrm{ZnS}$ indicated no significant neutron levels. 
Table 9-SURVEY OF CIT-NRC SYNCHROCYCLOTRON (FEB. 4, 1955) (Normal Field, Beryllium Target)

\begin{tabular}{|c|c|c|c|}
\hline Location & Instrument & Radiation level & $\begin{array}{c}\text { Fraction } \\
\text { of MPD } \\
\text { (neutrons) }\end{array}$ \\
\hline 101 & FND & $73 \mathrm{mrep} / \mathrm{hr}$ & 195 \\
\hline 102 & FND & $61 \mathrm{mrep} / \mathrm{hr}$ & 163 \\
\hline \multirow[t]{2}{*}{103} & TE chamber & $17.9 \mathrm{mrep} / \mathrm{hr}$ & \\
\hline & $\begin{array}{l}\text { FND } \\
\text { ZnS }\end{array}$ & $\begin{array}{l}17.5 \mathrm{mrep} / \mathrm{hr} \\
\text { Off scale }\end{array}$ & 47 \\
\hline \multirow[t]{4}{*}{105} & TE chamber & $2.1 \mathrm{mrep} / \mathrm{hr}$ & \\
\hline & FND & $2.4 \mathrm{mrep} / \mathrm{hr}$ & 6.4 \\
\hline & $\mathrm{ZnS}$ & $117 \mathrm{n}_{\mathrm{f}} / \mathrm{cm}^{2}-\mathrm{sec}$ & 7.8 \\
\hline & $\mathrm{BF}_{3}$ & $33 \mathrm{n}_{\mathrm{t}} / \mathrm{cm}^{2}-\mathrm{sec}$ & 0.02 \\
\hline 106 & $\mathrm{ZnS}$ & $11 \mathrm{n}_{\mathrm{f}} / \mathrm{cm}^{2}-\mathrm{sec}$ & 0.7 \\
\hline \multirow[t]{4}{*}{110} & TE chamber & $0.74 \mathrm{mrep} / \mathrm{hr}$ & \\
\hline & FND & $0.46 \mathrm{mrep} / \mathrm{hr}$ & 1.2 \\
\hline & $\mathrm{ZnS}$ & $13 n_{f} / \mathrm{cm}^{2}-\sec$ & 0.9 \\
\hline & $\mathrm{BF}_{3}$ & $19 \mathrm{n}_{\mathrm{t}} / \mathrm{cm}^{2}-\mathrm{sec}$ & 0.01 \\
\hline \multirow[t]{4}{*}{146} & TE chamber & $0.45 \mathrm{mrep} / \mathrm{hr}$ & 1.2 \\
\hline & FND & $0.26 \mathrm{mrep} / \mathrm{hr}$ & 0.7 \\
\hline & $\mathrm{ZnS}$ & $\sim 10 \mathrm{n}_{\mathrm{f}} / \mathrm{cm}^{2}-\mathrm{sec}$ & 0.7 \\
\hline & $\mathrm{BF}_{3}$ & $17 \mathrm{n}_{\mathrm{t}} / \mathrm{cm}^{2}-\mathrm{sec}$ & 0.01 \\
\hline \multirow[t]{2}{*}{141} & FND & $0.45 \mathrm{mrep} / \mathrm{hr}$ & 1.2 \\
\hline & $\mathrm{BF}_{3}$ & $22 \mathrm{n}_{\mathrm{t}} / \mathrm{cm}^{2}-\mathrm{sec}$ & 0.01 \\
\hline \multirow[t]{4}{*}{118} & TE chamber & $0.29 \mathrm{mrep} / \mathrm{hr}$ & \\
\hline & FND & $\sim 0.10 \mathrm{mrep} / \mathrm{hr}$ & $\sim 0.3$ \\
\hline & $\mathrm{ZnS}$ & $\sim 10 \mathrm{n}_{\mathrm{f}} / \mathrm{cm}^{2}-\mathrm{sec}$ & 0.7 \\
\hline & $\mathrm{BF}_{3}$ & $14 \mathrm{n}_{\mathrm{t}} / \mathrm{cm}^{2}-\mathrm{sec}$ & 0.01 \\
\hline 122 & $\begin{array}{l}\text { FND } \\
\text { ZnS }\end{array}$ & $\begin{array}{l}<0.1 \mathrm{mrep} / \mathrm{hr} \\
\text { Occasional count }\end{array}$ & $<0.3$ \\
\hline \multirow[t]{3}{*}{126} & TE chamber & $0.15 \mathrm{mrep} / \mathrm{hr}$ & \\
\hline & FND & $<0.10 \mathrm{mrep} / \mathrm{hr}$ & $<0.3$ \\
\hline & $\begin{array}{l}\mathrm{ZnS} \\
\mathrm{BF}_{3}\end{array}$ & $\begin{array}{l}\text { Occasional count } \\
14 n_{t} / \mathrm{cm}^{2}-\mathrm{sec}\end{array}$ & 0.01 \\
\hline 124 & $\mathrm{ZnS}$ & $\sim 10 \mathrm{n}_{\mathrm{f}} / \mathrm{cm}^{2}-\mathrm{sec}$ & 0.7 \\
\hline \multirow[t]{3}{*}{128} & TE chamber & $0.21 \mathrm{mrep} / \mathrm{hr}$ & \\
\hline & FND & $<0.1 \mathrm{mrep} / \mathrm{hr}$ & $<0.3$ \\
\hline & $\mathrm{ZnS}$ & Occasional count & \\
\hline \multirow[t]{2}{*}{ Control room } & $\mathrm{BF}_{3}$ & $\sim 1 \mathrm{n} t / \mathrm{cm}^{2}-\mathrm{sec}$ & \\
\hline & $\mathrm{ZnS}$ & Nothing detected & 0 \\
\hline \multirow[t]{3}{*}{223} & TE chamber & $0.18 \mathrm{mrep} / \mathrm{hr}$ & \\
\hline & FND & $\sim 0.1 \mathrm{mrep} / \mathrm{hr}$ & $\sim 0.3$ \\
\hline & $\mathrm{ZnS}$ & Occasional count & \\
\hline \multirow[t]{4}{*}{219} & TE chamber & $0.04 \mathrm{mrep} / \mathrm{hr}$ & \\
\hline & FND & Nothing detected & 0 \\
\hline & $\mathrm{ZnS}$ & Occasional count & \\
\hline & $\begin{array}{l}\mathrm{BF}_{3} \\
\mathrm{TE} \text { chamber }\end{array}$ & $\begin{array}{l}5 \mathrm{n}_{\mathrm{t}} / \mathrm{cm}^{2}-\mathrm{sec} \\
0.04 \mathrm{mrep} / \mathrm{hr}\end{array}$ & \\
\hline \multirow{3}{*}{218} & FND & Nothing detected & 0 \\
\hline & $\mathrm{ZnS}$ & Occasional count & \\
\hline & $\mathbf{B F}_{3}$ & $5 \mathrm{n}_{\mathrm{t}} / \mathrm{cm}^{2}-\mathrm{sec}$ & \\
\hline
\end{tabular}


It was understood that the emergency switches inside the vault, which are located near the vault doors, were not illuminated. It was also understood that these switches open the vault door, which in turn will turn off the cyclotron after the door has moved an inch or so. The possibility was suggested of illuminating these switches and modifying them so that the cyclotron is immediately deactivated (as in the case of the electric eye).

The use of an intercommunication system inside the vault was thought desirable so that the operator can announce "beam coming on" as an added safety device and so that persons inside the vault will be able to communicate with the outside.

It was suggested that the CIT fast neutron dosimeter calibration be checked.

\subsection{Bartol Research Foundation}

In March 1955 stray radiation measurements were made at the Bartol Research Foundation Cockcroft-Walton linear accelerator because of a 30-fold increase in the number of neutrons produced by it since a previous survey. At the time of the survey, the Cockcroft-Walton accelerated deuterons to about $100 \mathrm{kev}$ to produce $14 \mathrm{-Mev}$ neutrons as a result of the D-T reaction. The beam current on the tritium target was about $75 \mu \mathrm{a}$.

Neutron measurements are summarized in Tables 10 and 11. The thermal and fast neutron levels in the control area (locations 5 to 9, Fig. 9) were uniformly low, the maximum fast neutron levels encountered being 0.7 times the MPD. At locations 1 and 10 the passageways be-

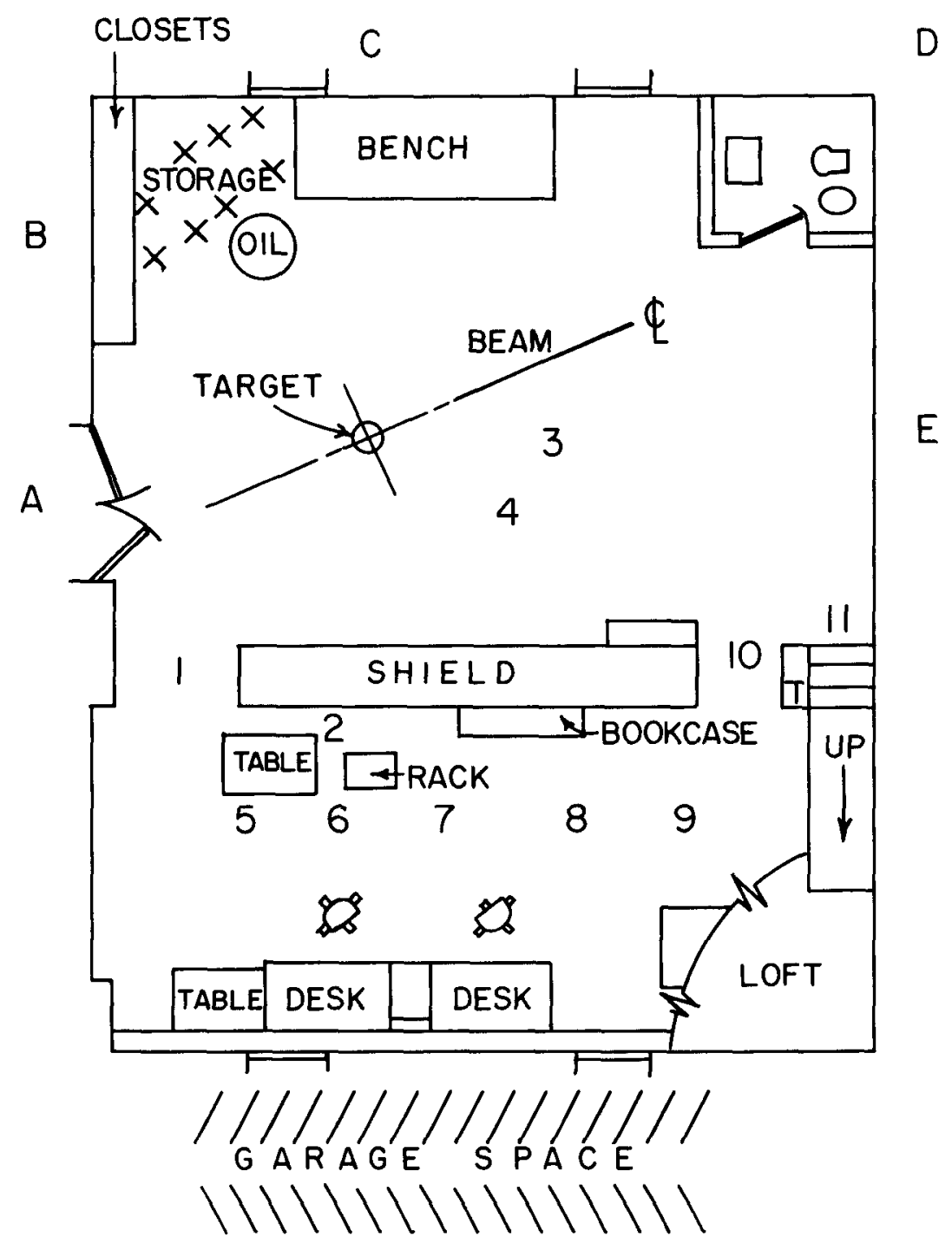

Fig. 9-Bartol Research Foundation Cockcroft-Walton accelerator layout, March 1955. 
Table 10-BARTOL RESEARCH FOUNDATION

COCKCROFT-WALTON ACCELERATOR (MAR. 22-23, 1955)

(100-kev Deuterons on Tritium; Beam on Tritium-Zirconium Target $=75 \mu$ )

\begin{tabular}{|c|c|c|c|}
\hline Location & Instrument & Radiation level & $\begin{array}{c}\text { Fraction } \\
\text { of MPD } \\
\text { (neutrons) }\end{array}$ \\
\hline \multirow[t]{3}{*}{1} & TE chamber & $3.13 \mathrm{mrep} / \mathrm{hr}$ & \\
\hline & FND & $1.75 \mathrm{mrep} / \mathrm{hr}$ & 4.7 \\
\hline & $\mathrm{ZnS}$ & $165 \mathrm{n} / \mathrm{cm}^{2}-\mathrm{sec}$ & 11.0 \\
\hline $\begin{array}{l}1 \text { (blank target, } \\
\text { quartz in place) }\end{array}$ & TE chamber & $0.17 \mathrm{mrep} / \mathrm{hr}$ & \\
\hline $2^{\text {quartz in place) }}$ & $\begin{array}{l}\text { ZnS } \\
\text { FND }\end{array}$ & $\begin{array}{l}\text { Nothing detected } \\
\sim 0.1 \mathrm{mrep} / \mathrm{hr}\end{array}$ & $\sim 0.3$ \\
\hline \multirow[t]{3}{*}{5 (6 ft behind shield end) } & TE chamber & $0.40 \mathrm{mrep} / \mathrm{hr}$ & \\
\hline & FND & $0.16 \mathrm{mrep} / \mathrm{hr}$ & 0.4 \\
\hline & $\mathrm{ZnS}$ & Occasional neutron & \\
\hline 5 (quartz target) & TE chamber & $0.15 \mathrm{mrep} / \mathrm{hr}$ & \\
\hline \multirow[t]{3}{*}{$6(6 \mathrm{ft}$ behind shield) } & TE chamber & $0.40 \mathrm{mrep} / \mathrm{hr}$ & \\
\hline & FND & $0.16 \mathrm{mrep} / \mathrm{hr}$ & 0.4 \\
\hline & $\mathrm{ZnS}$ & $\sim 10 \mathrm{n} / \mathrm{cm}^{2}-\mathrm{sec}$ & $\sim 0.7$ \\
\hline \multirow[t]{3}{*}{7 (6 ft behind shield) } & TE chamber & $0.40 \mathrm{mrep} / \mathrm{hr}$ & \\
\hline & FND & $\sim 0.1 \mathrm{mrep} / \mathrm{hr}$ & $\sim 0.3$ \\
\hline & $\mathrm{ZnS}$ & $\sim 10 \mathrm{n} / \mathrm{cm}^{2}-\mathrm{sec}$ & $\sim 0.7$ \\
\hline \multirow[t]{3}{*}{8 (6 ft behind shield) } & TE chamber & $0.29 \mathrm{mrep} / \mathrm{hr}$ & \\
\hline & FND & $\sim 0.1 \mathrm{mrep} / \mathrm{hr}$ & $\sim 0.3$ \\
\hline & $\mathrm{ZnS}$ & $\sim 10 \mathrm{n} / \mathrm{cm}^{2}-\mathrm{sec}$ & $\sim 0.7$ \\
\hline \multirow[t]{3}{*}{9 ( $6 \mathrm{ft}$ behind shield) } & TE chamber & $0.26 \mathrm{mrep} / \mathrm{hr}$ & \\
\hline & FND & $\sim 0.1 \mathrm{mrep} / \mathrm{hr}$ & $\sim 0.3$ \\
\hline & $\mathrm{ZnS}$ & $\sim 10 \mathrm{n} / \mathrm{cm}^{2}-\mathrm{sec}$ & $\sim 0.7$ \\
\hline \multirow[t]{3}{*}{10 (middle of passageway) } & TE chamber & $0.72 \mathrm{mrep} / \mathrm{hr}$ & \\
\hline & FND & $0.37 \mathrm{mrep} / \mathrm{hr}$ & 1.0 \\
\hline & $\mathrm{ZnS}$ & $80 \mathrm{n} / \mathrm{cm}^{2}-\mathrm{sec}$ & 5.3 \\
\hline 10 (quartz target) & TE chamber & $0.05 \mathrm{mrep} / \mathrm{hr}$ & \\
\hline 10 (telephone stand) & $\mathrm{ZnS}$ & $76 \mathrm{n} / \mathrm{cm}^{2}-\mathrm{sec}$ & 5.1 \\
\hline 11 (bottom stairs) & TE chamber & $1.85 \mathrm{mrep} / \mathrm{hr}$ & \\
\hline 11 (same, quartz target) & TE chamber & $0.16 \mathrm{mrep} / \mathrm{hr}$ & \\
\hline Halfway up stairs & $\mathrm{ZnS}$ & Occasional neutron & \\
\hline $10 \mathrm{~cm}$ from quartz target & $\mathrm{ZnS}$ & $14 \mathrm{n} / \mathrm{cm}^{2}-\mathrm{sec}$ & 0.93 \\
\hline $\begin{array}{l}3 \text { (200 } \mathrm{cm} \text { from quartz } \\
\text { target) }\end{array}$ & TE chamber & $0.34 \mathrm{mrep} / \mathrm{hr}$ & \\
\hline $3(200 \mathrm{~cm}$ from tritium $)$ & TE chamber & $6.15 \mathrm{mrep} / \mathrm{hr}$ & \\
\hline \multirow{2}{*}{$4(200 \mathrm{~cm}$ from target) } & $\mathrm{ZnS}$ & $260 \mathrm{n} / \mathrm{cm}^{2}-\mathrm{sec}^{*}$ & 17 \\
\hline & FND & $2.85 \mathrm{mrep} / \mathrm{hr} \dagger$ & 7.6 \\
\hline
\end{tabular}

* Equivalent to a Po-Be neutron yield of 1.3 to $1.4 \times 10^{8} \mathrm{n} / \mathrm{sec}$.

$\dagger$ Equivalent to a Po-Be neutron yield of $6.1 \times 10^{7} \mathrm{n} / \mathrm{sec}$.

Table 11 -BARTOL RESEARCH FOUNDATION

COCKCROFT-WALTON ACCELERATOR (MAR. 22-23, 1955)

$(100-k e v$ Deuterons on Tritium; Beam on Tritium-Zirconium Target $=75 \mu a)$

\begin{tabular}{lclc}
\hline Location & Instrument & $\begin{array}{c}\text { Radiation level, } \\
\mathrm{n} / \mathrm{cm}^{2}-\mathbf{s e c}\end{array}$ & $\begin{array}{c}\text { Fraction } \\
\text { of MPD } \\
\text { (neutrons) }\end{array}$ \\
\hline $\mathrm{A}$ & $\mathrm{ZnS}$ & $\mathbf{1 1 0}$ & 7.3 \\
$\mathrm{~B}$ & $\mathrm{ZnS}$ & $\mathbf{4 8}$ & 3.2 \\
$\mathrm{C}$ & $\mathrm{ZnS}$ & $\sim 10$ & $\sim 0.7$ \\
$\mathrm{D}$ & $\mathrm{ZnS}$ & Occasional neutron & \\
E & $\mathrm{ZnS}$ & $\mathbf{3 1}$ & 2.1 \\
F (parking lot, & $\mathrm{ZnS}$ & $\mathbf{1 4}$ & 0.9 \\
left of A) & & & \\
\hline
\end{tabular}


tween the control area and the target room were exposed to neutron dose rates about two to five times the maximum permissible level. Neutron scintillation counters indicated somewhat higher levels in terms of the maximum permissible, but this may be attributable to the increase of sensitivities of these scintillation counters with neutron energies.

Fast neutron levels around the outside of the Cockcroft-Walton building (Table 11) were as high as eight or nine times the maximum permissible fast neutron level near the building entrance. At location $F$ in the parking lot (about $15 \mathrm{ft}$ from the building), levels of the order of the maximum permissible were encountered.

With the quartz target substituted for the tritium-zirconium target, fast neutron fluxes of about $14 \mathrm{n} / \mathrm{cm}^{2}-\mathrm{sec}$ were found $(10 \mathrm{~cm}$ from quartz) because of the interaction of deuterons with deuterium deposited by the beam deuterons. Levels in locations 1 and 10 were insignificant during the use of the quartz blank.

Estimates of the 14-Mev neutron yield were made from scintillation and tissue equivalent proportional counter measurements. The Po-Be neutron yields corresponding to the measurements were $1.3 \times 10^{8} \mathrm{n} / \mathrm{sec}$ from the SBX-21A data and $6.1 \times 10^{7} \mathrm{n} / \mathrm{sec}$ from the fast neutron dosimeter data.

The work of Handloser and Higinbotham ${ }^{15}$ indicates that, for the same neutron flux, the counting rate for $14-\mathrm{Mev}$ neutrons can be expected to be about three times that for Po-Be neutrons (with the ZnS-Lucite scintillation neutron counter). Furthermore, the counting rate to tissue dose ratio of the Hurst proportional counter is believed to be essentially constant in this energy range. ${ }^{16}$ Thus the two neutron survey meters appear to be in substantial agreement. The Cockcroft-Walton neutron yield was estimated to be $6.1 \times 10^{7} \mathrm{n} / \mathrm{sec}$.

The recommendations made were as follows:

1. It was recommended that the concrete block shield located between the Cockcroft-Walton target room and the control area be lengthened to achieve narrower passageways (locations 1 and 10) and to provide a larger shadow of relatively low neutron levels in the control area.

2. It was recommended that positive barriers, possibly in the form of gates, be placed in the narrowed passageways leading to the target area.

3. It was recommended that suitable stray radiation warning devices be located near the entrance to the Cockcroft-Walton building for the benefit of Bartol personnel and their visitors. Since this Bartol accelerator is located on fenced-in private property in a thinly settled neighborhood, it would seem unnecessary to regard the exposure of the general public to neutron levels of the order of eight or nine times the maximum permissible level as a principal factor. However, it may be desirable to regulate the use of the parking area.

4. It was suggested that the possibility of interlocking the door leading to the CockcroftWalton building with the accelerator in operation be considered.

5. It was recommended that warning signs be erected near the sources of high voltage on the second floor of the Cockcroft-Walton building. The presence of unprotected screen shields at potentials of 50,000 or 100,000 volts is somewhat disconcerting.

\subsection{Stanford University}

During April members of HASL obtained stray radiation measurements at the Stanford Mark III linear electron accelerator (Fig. 10) with members of the High Energy Physics Laboratory to determine the possible neutron hazard. Essentially, two different approaches were used in the measurements: (1) the use of proportional counters by the Stanford group and (2) the use of ionization chambers by HASL.

Measurements were made during three modes of accelerator operation. The second and third are representative of a typical operation, whereas the first is a situation that does not occur too frequently.

1. The first condition, representing the worst one in terms of potential stray radiation hazard, was employed during the night of April 12 through the early morning of April 13. The electron beam was stopped at the halfway station (Fig. 11, location 10). The electrons achieved an energy of $260 \mathrm{Mev}$, the accelerator and the klystrons being pulsed 60 times/sec $\left(1.1 \times 10^{10}\right.$ electrons/beam pulse). The pulse duration of the klystrons was $2 \mu \mathrm{sec}$, whereas that of the beam was $0.6 \mu \mathrm{sec}$. The estimate of the number of electrons per pulse, as measured by a secondary emission detector, was believed to be correct within about a factor of 2 . 
2. During the second run, made the night of April 13, the 220-Mev electron beam was almost entirely stopped in the first halfway station by $8 \mathrm{in}$. of steel and $18 \mathrm{in}$. of concrete. The beam, $8 \times 10^{10}$ electrons/pulse, was estimated by a foil activation measurement and is believed to be correct within about 50 per cent. The frequency and duration of the beam and klystron pulses were the same as in the first run.

3. The final run, during the early morning hours of April 14, utilized the full electron energy available at the time of the survey (i.e., $500 \mathrm{Mev}$ ). The beam, as monitored by foil measurements at the halfway station and the secondary emission detector at the end station, was found to be about $3 \times 10^{10}$ electrons/pulse and $1 \times 10^{10}$ electrons/pulse, respectively. The pulse duration and frequency were the same as in the first run. Figure 12 shows the earth shield located at the beam end to reduce radiation levels in areas away from the accelerator site.

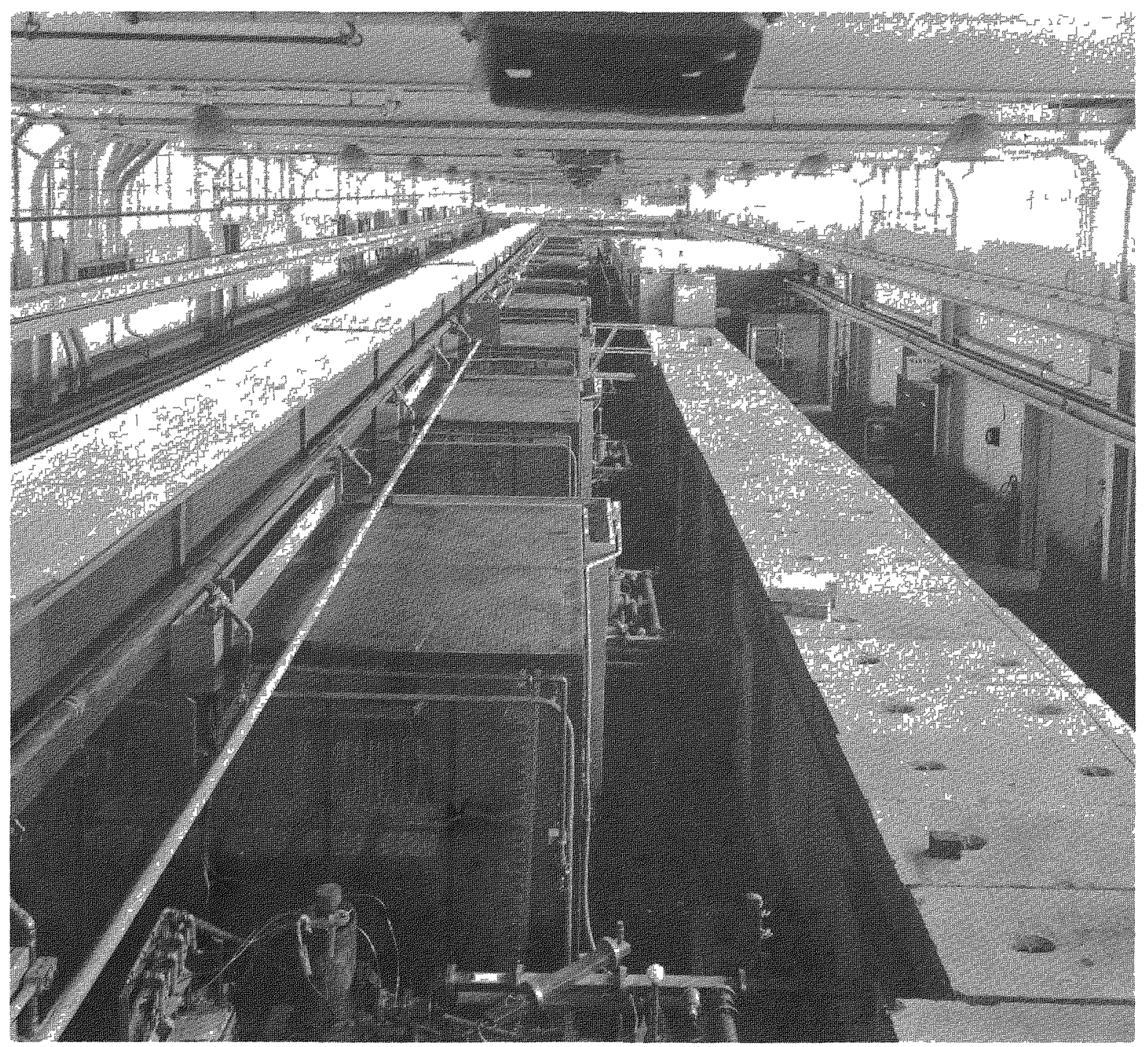

Fig. 10-Stanford University linear electron accelerator. 


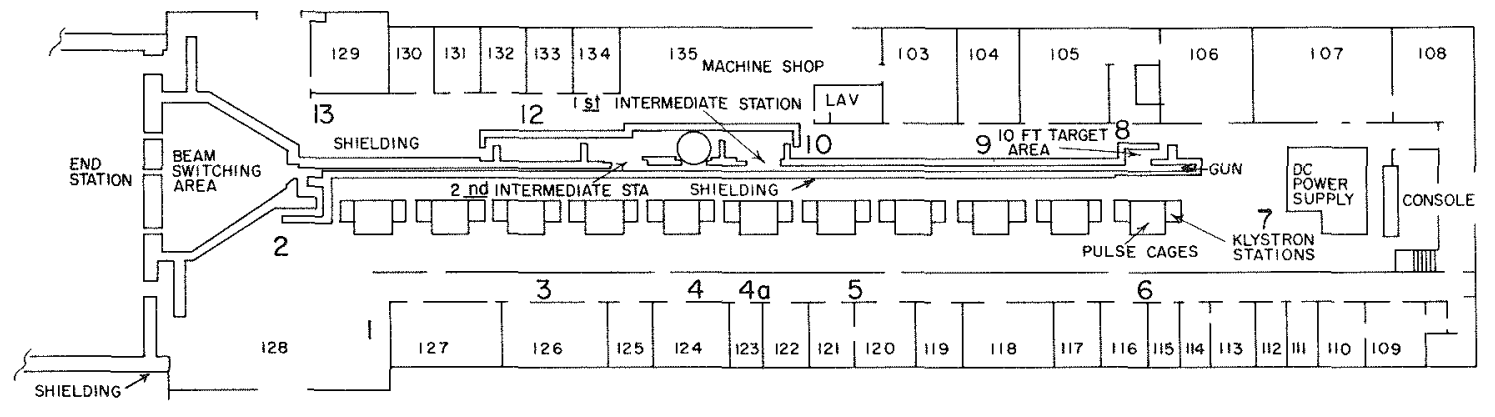

Fig. 11 - Stanford University Mark III linear electron accelerator layout, April 1955.

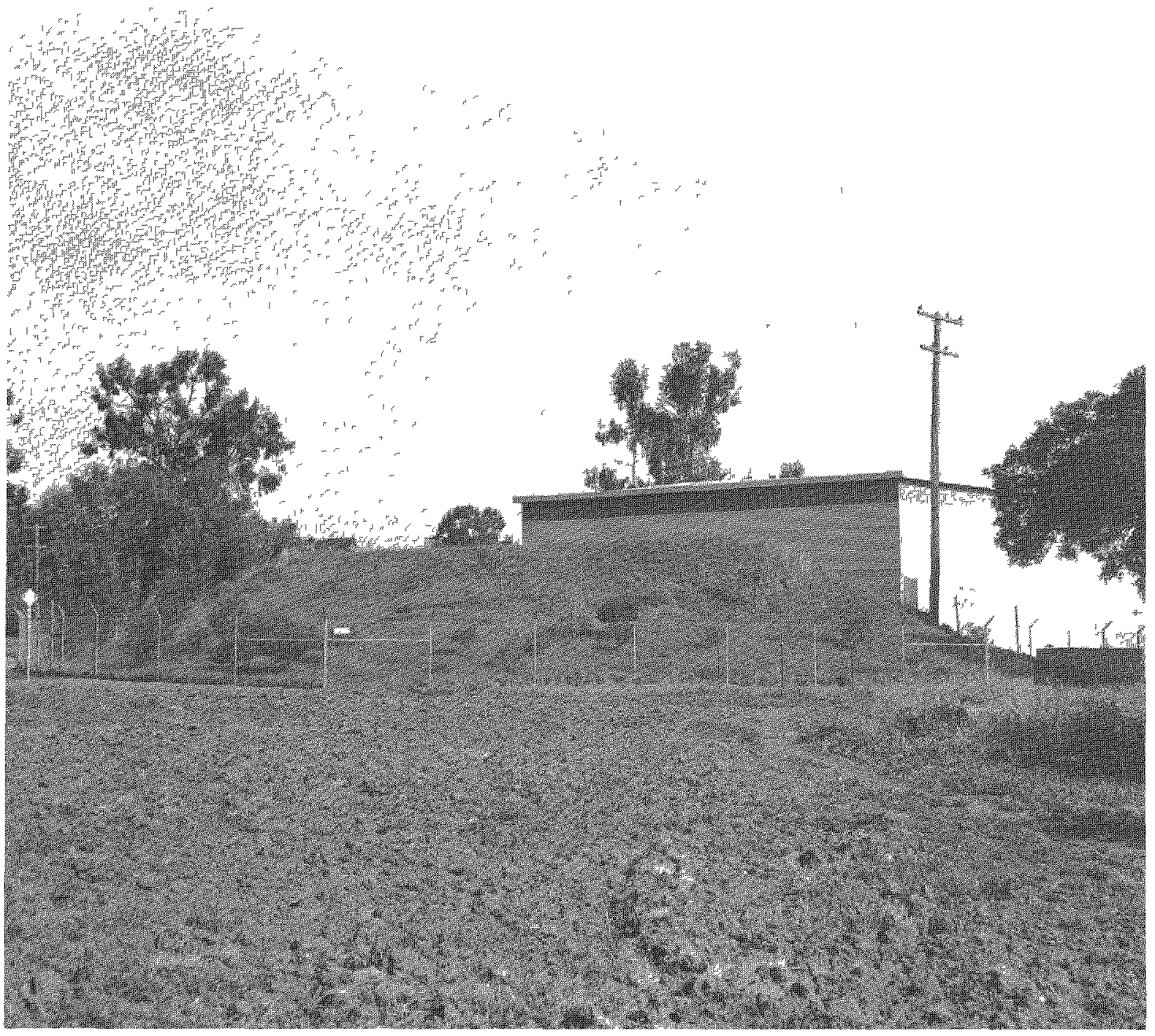

Fig. 12-Stanford University, earth shield at beam end of linear electron accelerator. 
The measurements for each run are recapitulated in Tables 12 to 14. Locations are marked on the floor plan of the Mark III (Fig. 11). The entries given in each column are described below.

Column 1: The gamma radiation level determined from the equations after subtraction of the $\mathrm{x}$-ray contribution of the klystron operation.

Column 2: The neutron flux (Po-Be equivalent) determined from the equations.

Column 3: The gamma-radiation level contributed by the klystron radiations as measured by the graphite- $\mathrm{CO}_{2}$ chamber.

Column 4: The gamma-radiation level contributed by the klystrons as measured by the tissue equivalent ionization chamber.

Column 5: The fast neutron proportional counter determination of the neutron level in terms of $\mathrm{Ra}-\mathrm{Be}$ equivalent.

Column 6: The $\mathrm{BF}_{3}$ long counter determination of the neutron level in terms of Ra-Be equivalent without a cadmium shield.

Column 7: The same measurement as in column 6, with the thermal neutron component removed by the cadmium shield.

Column 8: The SIC-17C ionization chamber reading with the beam on.

Column 9: The SIC-17C ionization chamber reading with only the klystrons operating, i.e., no electron beam.

Column 10: The $\mathrm{BF}_{3}$ portable counter measurement of the thermal flux. Since the maximum reading of this instrument occurs with a calculated thermal flux of 272 $\mathrm{n}_{\mathrm{t}} / \mathrm{cm}^{2} \mathrm{-sec}$, any off-scale measurements are interpreted as greater than this value.

In evaluating these measurements, the following observations were made.

1. The fast neutron levels, as measured by the fast neutron proportional counter, are in strong disagreement with the $\mathrm{BF}_{3}$ long counter and the ionization chamber determinations. For most positions the latter two are in substantial agreement.

2. The BNL fast neutron film badge packet does not indicate significant personnel exposures to fast neutrons and thus appears to be in essential agreement with the Stanford fast neutron proportional counter measurement.

3. A considerable number of the 508 components (beta-gamma packet) of the BNL-Stanford film records reveal cadmium reversal, i.e., a greater density under the cadmium strip in the film badge than under the "open window," or unshielded portion of the badge.

An explanation that appears to reconcile these observations is as follows:

1. There is a large contribution from low-energy neutrons to the stray radiation level as measured by both the tissue equivalent chamber and the $\mathrm{BF}_{3}$ long counter.

2. This large component is below the low-energy cutoff of the fast neutron proportional counter and also below the energy at which recognizable proton-recoil tracks can be produced in the NTA emulsions of the BNL film badges. It may be conjectured that the lower energy limit at which proton tracks are not recognizable, or recognized with very much diminished efficiency, is in the neighborhood of $0.5 \mathrm{Mev}$.

3. Because of this degraded neutron spectrum, a sufficient flux of thermal neutrons is expected to produce the cadmium reversal previously noted.

Absolute significance cannot be attributed to the neutron levels determined by these measurements. However, despite the absence of great precision, the evidence is strongly indicative of high neutron levels in the Mark II accelerator working areas. These high levels are believed to be comprised of a very much degraded spectrum, and for this reason their intensity is better represented by the measurements of Stanford's long counter and the HASL tissue equivalent ionization chamber than by those of the energy flux proportional counter.

1. The writers were inclined toward the view that daytime operation of this accelerator may be feasible if personnel occupancy times are appropriately regulated. Clearly, radiation levels would not permit unrestricted 40-hr occupancy in most accelerator work areas.

2. The methods of personnel control in terms of radiation and high-voltage interlocks appeared to be altogether adequate.

3. It is conjectured that the neutron spectrum is sufficiently degraded in energy and that low levels may be achieved in certain work areas with a small investment in hydrogenous 
Table 12-SURVEY DATA, FIRST RUN* (P.M. APR. 12 TO A.M. APR. 13,1955 )

[260-Mev Electrons; $1.1 \times 10^{10}$ Electrons/Pulse; 60 Pulses/sec; Pulse Duration $=2 \mu$ sec (Klystron), $0.6 \mu$ sec (Beam)]

\begin{tabular}{|c|c|c|c|c|c|c|c|c|c|c|}
\hline Location & $\begin{array}{c}(1) \\
\text { Net beam } \gamma \\
\text { (equations), } \\
\mathrm{mr} / \mathrm{hr}\end{array}$ & $\begin{array}{l}\quad(2) \\
\text { Net beam } \phi \\
\text { (equations), } \\
\mathrm{n} / \mathrm{cm}^{2}-\mathrm{sec}\end{array}$ & $\begin{array}{c}(3) \\
\text { Klystrons } \\
\left(\mathrm{C}-\mathrm{CO}_{2}\right), \\
\mathrm{mr} / \mathrm{hr}\end{array}$ & $\begin{array}{c}(4) \\
\text { Klystrons } \\
\text { (TE), } \\
\text { mrep/hr }\end{array}$ & 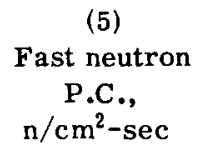 & $\begin{array}{c}(6) \\
\mathrm{BF}_{3} \mathrm{~L} . \mathrm{C} \text {. } \\
\text { without Cd, } \\
\mathrm{n} / \mathrm{cm}^{2}-\mathrm{sec}\end{array}$ & $\begin{array}{c}(7) \\
\mathrm{BF}_{3} \mathrm{~L} . \mathrm{C} \text {, } \\
\text { with Cd, } \\
\mathrm{n} / \mathrm{cm}^{2}-\mathrm{sec}\end{array}$ & $\begin{array}{c}(8) \\
\text { Beam } \gamma \\
\text { SIC-17C, } \dagger \\
\mathrm{mr} / \mathrm{hr}\end{array}$ & $\begin{array}{c}(9) \\
\text { Klystron } \gamma \\
\text { SIC-17C, } \dagger \\
\mathrm{mr} / \mathrm{hr}\end{array}$ & $\begin{array}{c}(10) \\
\mathrm{BF}_{3} \\
\text { portable, } \\
\mathrm{n} / \mathrm{cm}^{2}-\mathrm{sec}\end{array}$ \\
\hline 1 & \multicolumn{10}{|c|}{$\begin{array}{l}\text { Average } \mathrm{C}-\mathrm{CO}_{2} \text { instrumental "background" }=1.48 \pm 0.19 \mathrm{mv} / \mathrm{sec} \\
\text { Average TE instrumental "background" }=1.685 \pm 0.47 \mathrm{mv} / \mathrm{sec}\end{array}$} \\
\hline 2 & 2.12 & 93.6 & 0.254 & 0.890 & 1.6 & 12.6 & & N.D.t & N.D.革 & \\
\hline 3 & & & & & 3.5 & 25.7 & & & & \\
\hline 4 & 4.95 & 303 & 0.919 & 1.50 & 13.2 & 674 & & 10 & & \\
\hline 5 & 2.81 & 125 & 1.35 & 2.08 & 1.27 & 101 & & 9 & & \\
\hline 6 & 1.87 & 104 & 0.370 & 0.456 & 0.078 & 44 & & $\sim 5$ & $1-2$ & \\
\hline 7 & 0.596 & 49 & 0.122 & 0.211 & 0.028 & 1.95 & & 10 & & \\
\hline 8 & 5.62 & 200 & 0.239 & 0.445 & 0.357 & 10 & & 8.5 & & \\
\hline 9 & 3.85 & 147 & $\sim 0$ & 1.54 & 2.60 & 87.5 & & 9.5 & 3.5 & \\
\hline 10 & 20.2 & 517 & 0.973 & 1.53 & 10.7 & 683 & & 40 & $\sim 4$ & \\
\hline 11 & 1.45 & 99.4 & 0.029 & 0.008 & 1.10 & 75 & & 5 & $\sim 0$ & \\
\hline 12 & 6.16 & 314 & $\sim 0$ & $\sim 0$ & 1.30 & 157 & & 16.5 & & \\
\hline 13 & 10.1 & 552 & 0.204 & 0.293 & 0.55 & 270 & & 29 & $\sim 0$ & \\
\hline
\end{tabular}

* No data were obtained for columns 7 and 10.

†SIC-17C measurement made only through thin rubber hydrochloride window.

$\$$ Nothing detected. 
Table 13-SURVEY DATA, SECOND RUN (P.M. APR. 13, 1955)

[220-Mev Electrons; $8 \times 10^{10}$ Electrons/Pulse; 60 Pulses/sec; Pulse Duration $=2 \mu$ sec (Klystron), $0.6 \mu$ Sec $($ Beam) $]$

\begin{tabular}{|c|c|c|c|c|c|c|c|c|c|c|}
\hline Location & $\begin{array}{c}\text { (1) } \\
\text { Net beam } \gamma \\
\text { (equations), } \\
\mathrm{mr} / \mathrm{hr}\end{array}$ & $\begin{array}{c}(2) \\
\text { Net beam } \phi \\
\text { (equations), } \\
\mathrm{n} / \mathrm{cm}^{2}-\mathrm{sec}\end{array}$ & $\begin{array}{c}(3) \\
\text { Klystrons } \\
\left(\mathrm{C}-\mathrm{CO}_{2}\right), \\
\mathrm{mr} / \mathrm{hr}\end{array}$ & $\begin{array}{c}(4) \\
\text { Klystrons } \\
(\mathrm{TE}), \\
\text { mrep/hr }\end{array}$ & $\begin{array}{c}\text { (5) } \\
\text { Fast neutron } \\
\text { P.C., } \\
\text { n/cm } \mathrm{cm}^{2}-\mathrm{sec}\end{array}$ & $\begin{array}{c}(6) \\
\mathrm{BF}_{3} \text { L.C. } \\
\text { without } \mathrm{Cd} \text {, } \\
\mathrm{n} / \mathrm{cm}^{2}-\mathrm{sec}\end{array}$ & $\begin{array}{c}\text { (7) } \\
\mathrm{BF}_{3} \mathrm{~L} . \mathrm{C} \text {. } \\
\text { with Cd, } \\
\mathrm{n} / \mathrm{cm}^{2}-\mathrm{sec}\end{array}$ & $\begin{array}{c}(8) \\
\text { Beam } \gamma \\
\text { SIC-17C, } \\
\mathrm{mr} / \mathrm{hr}\end{array}$ & $\begin{array}{c}(9) \\
\text { Klystron } \gamma \\
\text { SIC-17C, } \\
\mathrm{mr} / \mathrm{hr}\end{array}$ & $\begin{array}{c}(10) \\
\mathrm{BF}_{3} \\
\text { portable, } \\
\mathrm{n} / \mathrm{cm}^{2}-\mathrm{sec}\end{array}$ \\
\hline 13 & 0.074 & 7.25 & $\sim 0$ & 0.12 & 0 & 4.2 & & $\sim 0$ & $\sim 0$ & \\
\hline 12 & 0.118 & 8.4 & $\sim 0$ & $\sim 0$ & 0.075 & 5.3 & & $\sim 0$ & $\sim 0$ & \\
\hline 11 & 2.71 & 173 & 0.04 & $\sim 0$ & 0.55 & 128 & 46 & 6 & $\sim 0$ & \\
\hline 10 & 41.8 & 1330 & 0.81 & 1.31 & 51 & 2748 & 1758 & 70 & $\sim 1$ & \\
\hline 9 & 10.9 & 378 & 0.65 & 1.11 & 4.27 & 409.6 & 303 & 15 & $1-2$ & $>272$ \\
\hline 5 & 5.42 & 237 & 1.54 & 2.22 & 0.47 & 353 & 179 & 19 & & \\
\hline 4 & 1.80 & 70.2 & 0.34 & 0.38 & 2.27 & 375 & 192 & 5.5 & $\sim 0$ & $>272$ \\
\hline 3 & 0.313 & 10.4 & 0.37 & 0.59 & & 28.1 & 13.9 & 1.5 & $\sim 0$ & 54.4 \\
\hline
\end{tabular}

Table 14-SURVEY DATA, THIRD RUN (A.M. APR. 14, 1955)

[500-Mev Electrons; $3 \times 10^{10}$ Electrons/Pulse (Halfway Station), $1 \times 10^{10}$ Electrons/Pulse

(End Station); 60 Pulses/sec; Pulse Duration $=2 \mu \mathrm{sec}$ (Klystron), $0.6 \mu \mathrm{sec}$ (Beam)]

\begin{tabular}{|c|c|c|c|c|c|c|c|c|c|c|}
\hline Location & $\begin{array}{c}\text { (1) } \\
\text { Net beam } \gamma \\
\text { (equations), } \\
\mathrm{mr} / \mathrm{hr}\end{array}$ & $\begin{array}{l}(2) \\
\text { Net beam } \phi \\
\text { (equations), } \\
\mathrm{n} / \mathrm{cm}^{2}-\mathrm{sec}\end{array}$ & $\begin{array}{c}\text { (3) } \\
\text { Klystrons } \\
\left(\mathrm{C}-\mathrm{CO}_{2}\right) \text {, } \\
\mathrm{mr} / \mathrm{hr}\end{array}$ & $\begin{array}{c}\text { (4) } \\
\text { Klystrons } \\
\text { (TE), } \\
\text { mrep/hr }\end{array}$ & $\begin{array}{c}\text { (5) } \\
\text { Fast neutron } \\
\text { P.C., } \\
\text { n/cm }{ }^{2}-\text { sec }\end{array}$ & $\begin{array}{c}(6) \\
\mathrm{BF}_{3} \text { L.C. } \\
\text { without Cd, } \\
\mathrm{n} / \mathrm{cm}^{2}-\mathrm{sec}\end{array}$ & $\begin{array}{c}(7) \\
\mathrm{BF}_{3} \mathrm{~L} . \mathrm{C} . \\
\text { with Cd, } \\
\mathrm{n} / \mathrm{cm}^{2}-\mathrm{sec}\end{array}$ & $\begin{array}{c}(8) \\
\text { Beam } \gamma \\
\text { SIC-17C, } \\
\mathrm{mr} / \mathrm{hr}\end{array}$ & $\begin{array}{c}\text { (9) } \\
\text { Klystron } \gamma \\
\text { SIC-17C, } \\
\mathrm{mr} / \mathrm{hr}\end{array}$ & $\begin{array}{c}(10) \\
\mathrm{BF}_{3} \\
\text { portable, } \\
\mathrm{n} / \mathrm{cm}^{2}-\mathrm{sec}\end{array}$ \\
\hline 3 & 1.85 & 174 & 0.649 & 0.645 & 2.8 & 172 & 76.8 & 5.5 & $\sim 0$ & \\
\hline 2 & 2.22 & 123 & 0.136 & $\sim 0$ & 1.7 & 62.9 & 42.5 & 5 & $\sim 1$ & 163 \\
\hline $4 a$ & 5.77 & 369 & 5.40 & 8.28 & 11.2 & 964 & 860 & 23 & 13 & $>272$ \\
\hline 10 & 37.5 & 805 & 1.15 & 1.62 & 45.6 & 1732 & 1178 & 75 & 3.5 & $>272$ \\
\hline 11 & 2.24 & 375 & $\sim 0$ & $\sim 0$ & 1.03 & 101 & 43 & 5.5 & $\sim 0$ & $>272$ \\
\hline 12 & 1.65 & 129 & $\sim 0$ & $\sim 0$ & 0.72 & 26.7 & 20 & 3.5 & $\sim 0$ & 218 \\
\hline 13 & 2.54 & 105 & 0.054 & $\sim 0$ & 1.6 & 79.9 & 56.5 & 6 & 20 & 136 \\
\hline
\end{tabular}


shielding, e.g., placing tanks of water around the machine shop rather than along the accelerator wall. It may be possible that a modest program along these lines may one day permit unrestricted daytime operation of this accelerator.

4. It was recommended that the low-energy cutoff of the energy flux proportional counter be precisely determined.

\subsection{University of California}

Stray radiation measurements obtained during operation of the University of California Radiation Laboratory (UCRL) proton synchrotron (Bevatron) and the 184-in. synchrocyclotron are reported below.

(a) Bevatron. During the survey the synchrotron was pulsed about 16 times/min, the proton achieving energies of about 4.8 Bev. Because of the relatively long time between beam pulses ( 1 pulse/ 4 sec), measurements were made only with the HASL tissue equivalent and graphite $-\mathrm{CO}_{2}$ ionization chambers and a fast neutron dosimeter. The usual scintillation neutron rate meters were unusable because of the synchrotron pulsing and the strong magnetic field. Concurrent measurements made by the UCRL health physics group are not reported here. In one or two locations, e.g., bay 16 (Fig. 13), even the ionization chamber-electrometer combinations were unusable because of the effect of the magnet on these instruments. Bay 16 is beyond the end of the concrete radiation shield, thus the magnet was not shielded from any instruments in this vicinity. The magnetic effect in this location was established by repeated measurements during Bevatron operation, during the injector accelerator operation only, and with only this magnet on.

All measurements on the ground level, as well as on the balcony, were made with the radiation detectors located about $4 \mathrm{ft}$ above the floor (see cart in Fig. 14). Results are listed in Table 15. The neutron fluxes and gamma rays, inferred from the ionization chamber results, are the equivalent Po-Be neutron fluxes and radium gamma levels.

The second column of Table 15 indicates the beam condition during the time of the integrating run. That is, the time to accumulate the actual reading (charge collected in the case of the ionization chambers) was also the time of synchrotron operation to accelerate about $6 \times 10^{10}$ protons.

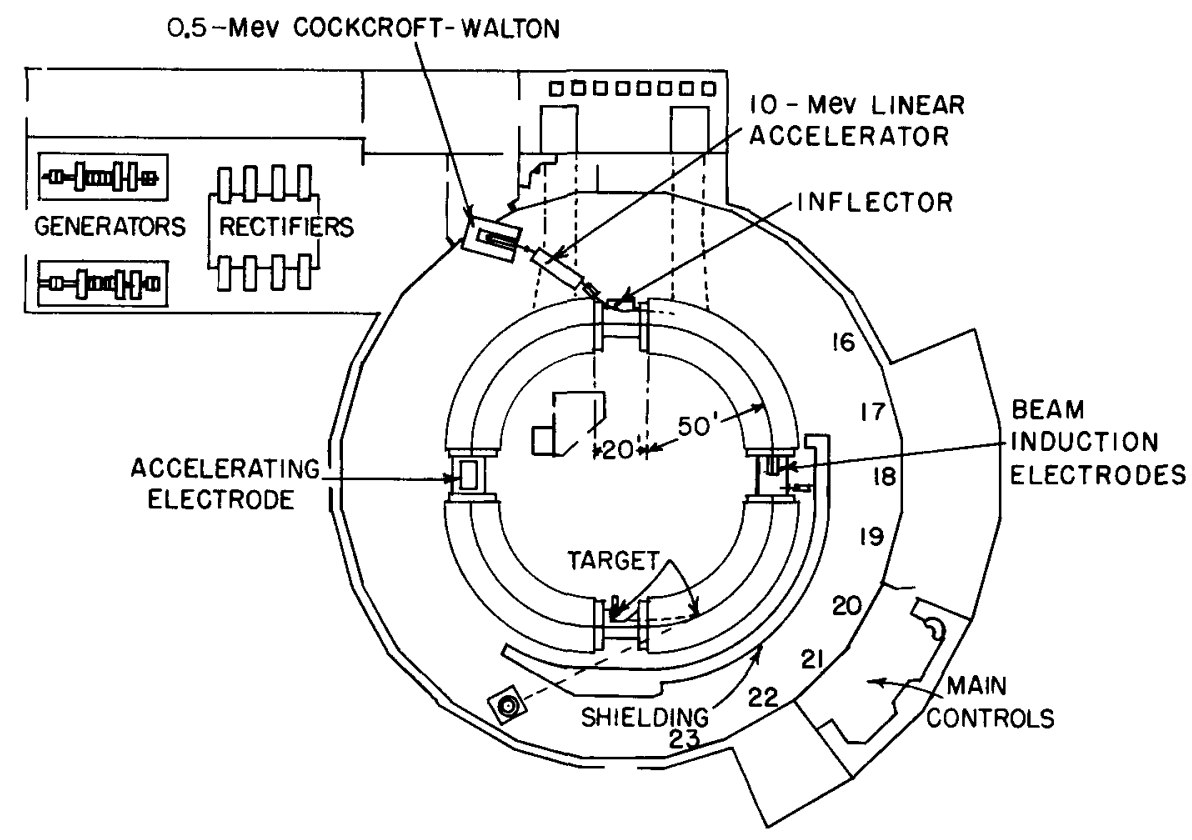

Fig. 13 - University of California Radiation Laboratory Bevatron layout, 1955. 
The calculated equivalent Po-Be neutron fluxes were uniformly low. The highest flux encountered, which can be regarded as really neutrons, was only about 0.4 of the maximum permissible flux, taken to be $30 \mathrm{n} / \mathrm{cm}^{2}-\mathrm{sec}$. The high readings observed in bays 16 and 17 were attributed to the effect of the accelerator magnet on the instruments rather than to neutrons. This conclusion was verified by the experiment summarized in the last entry of Table 15. The reason the tissue equivalent chamber read so much higher than the graphite $-\mathrm{CO}_{2}$ chamber is not clear. It should be pointed out, however, that both chambers are operated with a collecting voltage applied to the shell of the chamber. The graphite chamber, though, is canned in aluminum; since the chamber wall itself is not exposed, the aluminum may shield the chamber wall electrostatically. The apparent greater sensitivity of the ionization chambers, as compared to the fast neutron dosimeter, was attributed to the presence of neutron energies below the dosimeter cutoff.

The high background values reported for the no-beam condition in bay 19 were attributed to the radiation source storage safe in this vicinity. Thus the inferred neutron flux, $7.2 \mathrm{n} / \mathrm{cm}^{2}-$ $\mathrm{sec}$, is entirely fictitious. In a qualitative sense, if this flux is subtracted from the beam-on value, $12.8 \mathrm{n} / \mathrm{cm}^{2}-\mathrm{sec}$, the resulting difference is approximately equal to the inferred flux obtained in the nearby location, bay 20 . On the other hand, the flux encountered in bay 18 is approximately the same as that in bay 19 for the beam-on condition. The writers suspected that these relatively high fluxes (of the order of $10 \mathrm{n} / \mathrm{cm}^{2}-\mathrm{sec}$ ) are mostly attributable to the aforementioned high background produced by the radiation storage safe. Thus the fluxes in bays 19 and 18 were probably about $5 \mathrm{n} / \mathrm{cm}^{2}-\mathrm{sec}$, as in bay 20 .

Measurements made in the balcony area of the Bevatron building during the evening of April 19 indicate that the stray radiation levels were utterly insignificant with respect to maximum permissible neutron and $\mathrm{x}$-ray levels. The tissue equivalent chamber, which furnishes a measure of total tissue doses, was never significantly above background.

Since the measurements reported here do not constitute a complete stray radiation profile of the UCRL Bevatron area, no recommendations regarding occupancy times in the Bevatron building are made.

From the results obtained, however, it appears that the radiation levels are uniformly low and appear consistent with full-time occupancy in places near bays 23 to 16 when the Bevatron is operated as on the survey date.

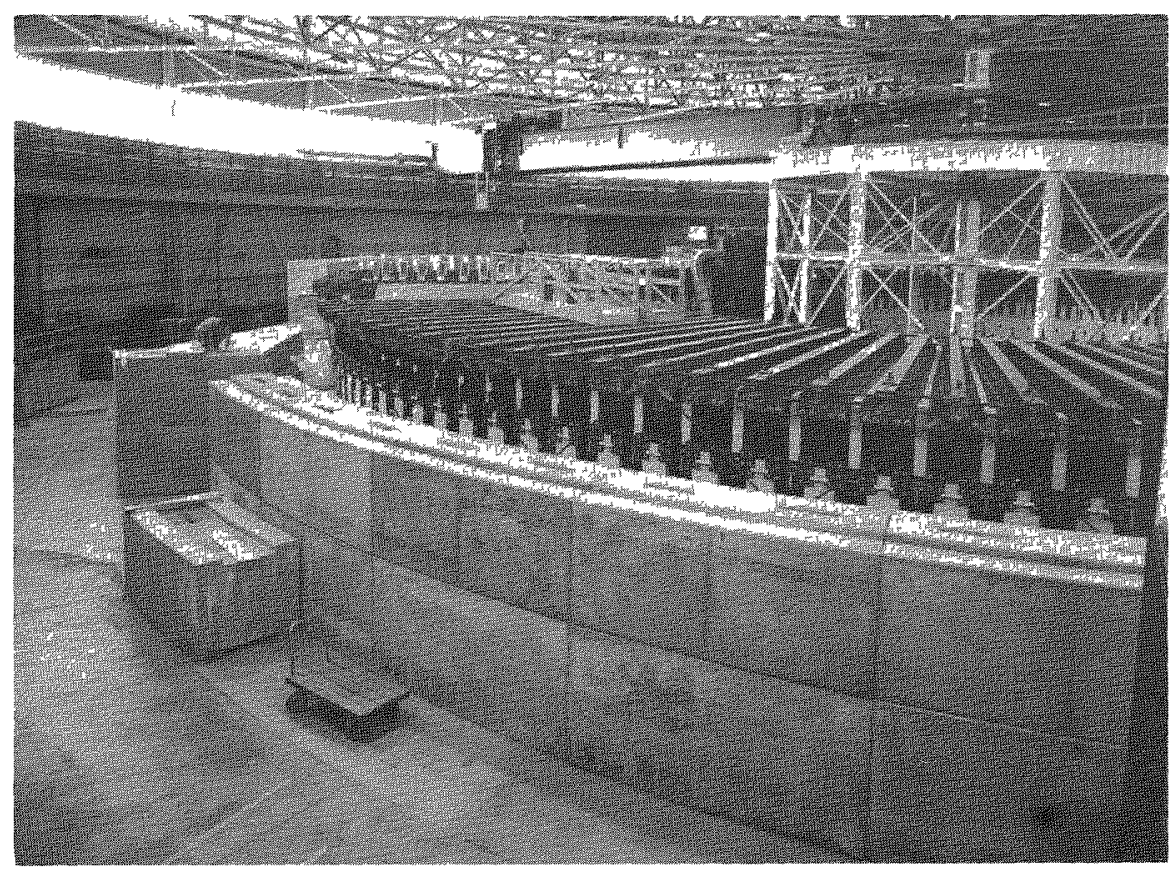

Fig. 14-University of California Radiation Laboratory Bevatron. 
Table 15-SUMMARY OF STRAY RADIATION MEASUREMENTS AT UNIVERSITY OF

CALIFORNIA RADIATION LABORATORY BEVATRON (APR. 19, 1955)

[4.8-Bev $\mathrm{H}^{1}$ (Beam Conditions As Indicated)]

\begin{tabular}{|c|c|c|c|c|c|c|c|c|c|}
\hline \multirow[b]{2}{*}{ Location } & \multirow{2}{*}{$\begin{array}{l}\text { Beam, } \\
\text { No. protons } \\
\text { in No. pulses }\end{array}$} & \multirow{2}{*}{$\begin{array}{c}\text { Fast } \\
\text { neutron } \\
\text { dosimeter, } \\
\text { mrep/hr }\end{array}$} & \multicolumn{2}{|c|}{$\begin{array}{l}\mathrm{TE} \text { chamber } \\
\text { readings, } \mathrm{mv} / \mathrm{sec}\end{array}$} & \multicolumn{2}{|c|}{$\begin{array}{l}\mathrm{CO}_{2} \text { chamber } \\
\text { readings, mv/sec }\end{array}$} & \multirow{2}{*}{$\begin{array}{c}\phi \\
\text { calculated, } \\
\mathrm{n} / \mathrm{cm}^{2}-\mathrm{sec}\end{array}$} & \multirow{2}{*}{$\begin{array}{l}\text { Fraction of } \\
30 \mathrm{n} / \mathrm{cm}^{2}-\mathrm{sec}\end{array}$} & \multirow{2}{*}{$\begin{array}{c}\gamma \\
\text { calculated, } \\
\mathrm{mr} / \mathrm{hr}\end{array}$} \\
\hline & & & Gross & Net & Gross & Net & & & \\
\hline Bay 23 & $6 \times 10^{10}$ in 38 & & 1.1515 & 0.3479 & 1.1818 & 0.4853 & 5.68 & 0.19 & 0.04 \\
\hline Bay 23 & $6 \times 10^{10}$ in 45 & & 1.2239 & 0.4203 & 1.0881 & 1.1237 & 4.30 & 0.14 & 0.09 \\
\hline Bay 22 & $6 \times 10^{10}$ in 52 & $<0.1$ & 1.1666 & 0.3630 & 1.4286 & 0.7321 & 4.85 & 0.16 & 0.06 \\
\hline Bay 22 & $6 \times 10^{10}$ in 53 & $<0.1$ & 1.2093 & 0.4057 & 1.4419 & 0.7454 & 5.77 & 0.19 & 0.06 \\
\hline Bay 21 & $6 \times 10^{10}$ in 55 & $<0.1$ & 1.1688 & 0.3652 & 1.1255 & 0.4290 & 6.35 & 0.21 & 0.04 \\
\hline Bay 21 & $6 \times 10^{10}$ in 44 & & 1.1714 & 0.3678 & 1.3429 & 0.6464 & 5.37 & 0.18 & 0.05 \\
\hline Bay 20 & $6 \times 10^{10}$ in 47 & & 1.1421 & 0.3385 & 1.2183 & 0.5218 & 5.29 & 0.18 & 0.04 \\
\hline Bay 19 & No beam & & 1.1070 & 0.3304 & 0.7772 & 0.0807 & 7.21 & & 0.006 \\
\hline Bay 19 & $6 \times 10^{10}$ in 74 & $<0.1$ & 1.5349 & 0.7313 & 1.5325 & 0.8360 & 12.82 & 0.43 & 0.07 \\
\hline Bay 18 & $6 \times 10^{10}$ in 45 & $<0.1$ & 1.5695 & 0.7659 & 1.7489 & 1.0524 & 12.59 & 0.42 & 0.09 \\
\hline Bay 18 & $\begin{array}{l}6 \times 10^{10} \text { in } 35 \\
\text { (not plunging target) }\end{array}$ & $<0.1$ & 1.4685 & 0.6659 & 1.7133 & 1.0168 & 10.46 & 0.35 & 0.085 \\
\hline $\begin{array}{l}\text { Bay } 18 \\
\quad \text { (repeat) }\end{array}$ & $6 \times 10^{10}$ in 73 & & 1.4750 & 0.6714 & 1.0375 & 0.3410 & 13.81 & 0.46 & 0.03 \\
\hline Bay 17 & $\begin{array}{l}4.86 \times 10^{10} \text { in } 40 \\
\text { (no shield in } \\
\text { this location) }\end{array}$ & $\sim 0.3$ & $2.8406^{*}$ & 2.0370 & $4.2899^{*}$ & 3.5934 & & & \\
\hline Bay 16 & $0.58 \times 10^{10}$ in 10 & & $20.2532 \dagger$ & & 1.5385 & 0.8420 & & & \\
\hline Bay 16 & $\begin{array}{l}\text { Only beam is } 0.48 \\
\text { proton from } \\
\text { linear accelerator }\end{array}$ & & $22.7273 \dagger$ & & 0.7307 & & & & \\
\hline
\end{tabular}

* The HASL 1-mg radium check source indicated correct response after this run. High reading may be due to magnet of accelerator.

$\dagger$ High reading caused by magnetic field. 
(b) Synchrocyclotron. Measurements were made in six locations in occupied areas near the UCRL synchrocyclotron shield (Figs. 15 and 16). The radiation was produced by the interaction of 340-Mev protons in a 2-in.-thick beryllium target. Figure 16 is a general view of the accelerator; location 4 is next to the shield door on the left-hand side of this picture. All measurements were made about $4 \mathrm{ft}$ above the floor. Results of the measurements appear in Table 16.

In most cases the ionization chamber electrometer readings did not appear to be too much above background. The neutron fluxes and gamma-ray levels resulting from these measurements are quite low, being only small fractions of the maximum permissible level. The maximum fraction of neutron maximum permissible flux encountered was about 0.40 (assuming the maximum flux of Po-Be neutrons is $30 \mathrm{n} / \mathrm{cm}^{2}-\mathrm{sec}$ ) at location 1 (Table 16). All gamma-ray levels appeared to be extremely low.

These generally low levels agree, at least in a qualitative sense, with the results obtained with the fast neutron dosimeter and the $\mathrm{BF}_{3}$ survey meter. It should be noted that this particular $\mathrm{BF}_{3}$ counter contains a gas enriched in the $\mathrm{B}^{10}$ isotope and can be a sensitive detector of the presence of any neutrons. Thus the low thermal neutron fluxes indicate negligible intermediate and fast neutrons.

Since measurements were made in only a few locations, no specific recommendations appeared necessary.

This survey, as well as the Stanford survey, involved the initial field use of the HASL graphite $-\mathrm{CO}_{2}$ ionization chamber. In general, the results were quite gratifying and seemed to represent surprisingly well the stray radiation profile in the locations studied near the UCRL Bevatron and synchrocyclotron.

Several modifications that seem desirable for the future, however, are indicated.

1. The rather high instrumental backgrounds tended to limit the effectiveness of the lower end of the ionization chamber-vibrating-reed electrometer combinations. These high readings were largely attributed to leakage currents across various components in the input resistor housings and electrometer heads. Periodic proper cleaning tends to reduce the background readings considerably. Although the vibrating-reed electrometer is essentially a laboratory instrument, it is believed that this proper cleaning, as well as adequate warm-up times, will permit the writers to increase the precision of low-level radiation measurements.

2. It is planned to incorporate a $\mathrm{BF}_{3}$ ionization chamber, calibrated with Po-Be neutrons, into the HASL instrumentation. Thus the total radiation dose would be differentiated into the neutron and electromagnetic radiation components by means of the graphite $-\mathrm{CO}_{2}$ and $\mathrm{BF}_{3}$ ionization chamber measurements only. The tissue equivalent chamber then would furnish a measure of the validity of the division of the total stray radiation dose by the graphite- $\mathrm{CO}_{2}$ and $\mathrm{BF}_{3}$ ionization chambers.

\subsection{State University of Iowa}

In July 1955 members of HASL obtained stray radiation measurements at two accelerators: a positive ion Van de Graaff and a Cockcroft-Walton generator. The horizontal Van de Graaff is capable of accelerating positive ions to 3 to $5 \mathrm{Mev}$. During the survey, 2-Mev protons bombarded a brass beam stopper. Because this energy is below the threshold for $(p, n)$ reactions involving the important constituents of the target (with the exception of $\mathrm{Zn}^{67}$, which has a 1.79-Mev threshold and a 4 per cent abundance in normal isotopic zinc), an altogether negligible neutron production was expected. The Cockcroft-Walton generator accelerated a 100$\mu \mathrm{a}$ beam of deuterons to $400 \mathrm{kev}$ toward a deuterium target. The yield of $\mathrm{D}-\mathrm{D}$ neutrons was roughly estimated to be $10^{8} \mathrm{n} / \mathrm{sec}$.

A summary of the Van de Graaff measurements is given in Table 17 and relates to the floor plan in Fig. 17. In occupied areas the gamma-ray levels were uniformly insignificant. $\mathrm{X}$-ray levels from back electron bremsstrahlung in the generator tank reached levels up to $270 \mathrm{mr} / \mathrm{hr}$ on the outside of the tank (positions 1 through 10). Because of the operating condition, neutron levels were entirely negligible, although easily detectable with the $\mathrm{BF}_{3}$ long counter near the deflecting magnet (position 12) and at the table (position 13).

Rather detailed measurements were performed with the $\mathrm{BF}_{3}$ long counter in the laboratory adjoining the Cockcroft-Walton accelerator room (Fig. 18). The results are presented in 


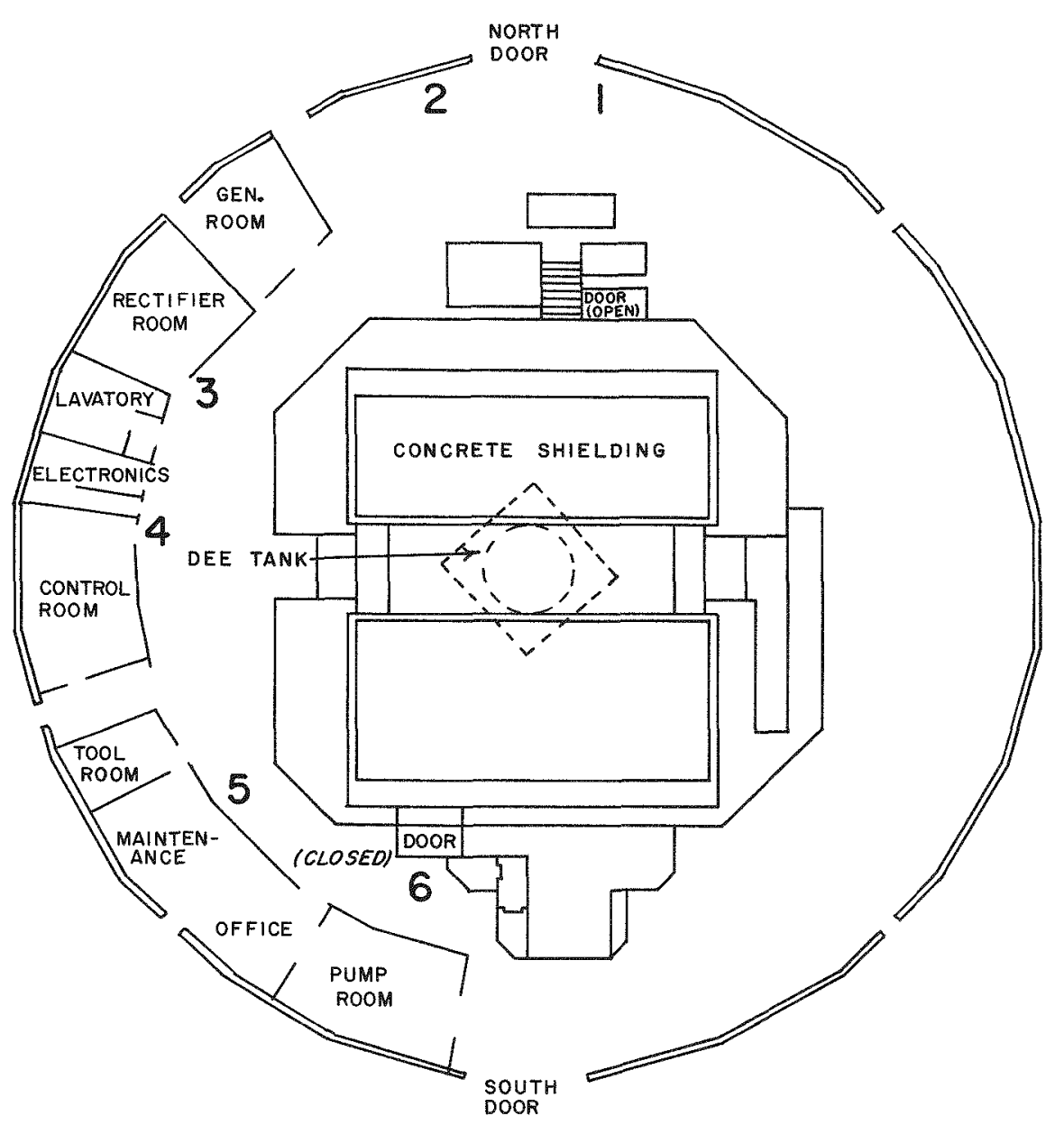

Fig. 15-University of California Radiation Laboratory synchrocyclotron layout, 1955.

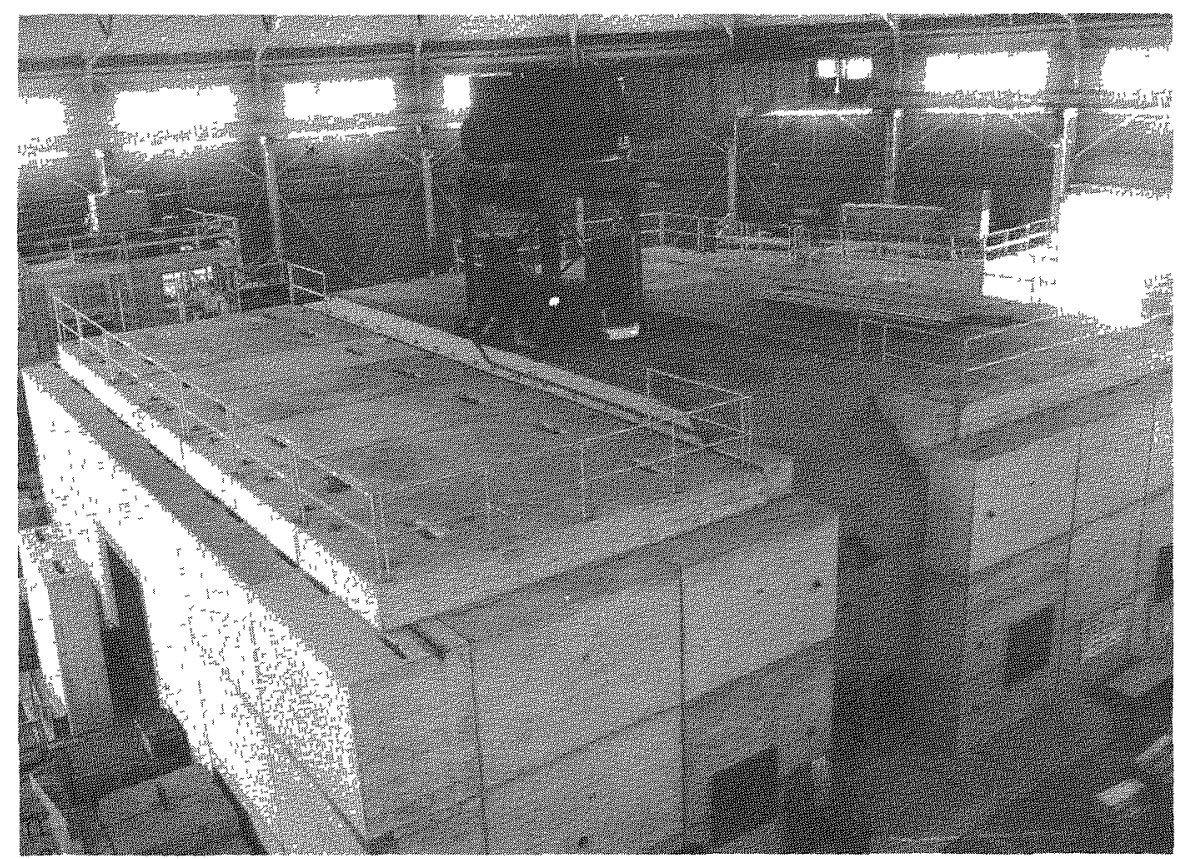

Fig. 16-University of California Radiation Laboratory synchrocyclotron. 
Table 16-SUMMARY OF STRAY RADIATION MEASUREMENTS AT UNIVERSITY OF CALIFORNIA RADIATION LABORATORY 184-IN. SYNCHROCYCLOTRON (APR. 19, 1955) [340-Mev $\mathrm{H}^{1}$ on $\mathrm{Be}^{9}(2-$ in. target $\left.)\right]$

\begin{tabular}{|c|c|c|c|c|c|c|c|c|c|c|c|}
\hline \multirow[b]{2}{*}{ Location } & \multirow[b]{2}{*}{ Description } & \multirow{2}{*}{$\begin{array}{c}\text { HASL } \\
\mathrm{BF}_{3}, \\
\mathrm{n}_{\mathrm{t}} / \mathrm{cm}^{2}-\mathrm{sec}\end{array}$} & \multicolumn{2}{|c|}{ Fast neutron dosimeter } & \multicolumn{2}{|c|}{$\begin{array}{l}\mathrm{TE} \text { chamber } \\
\text { readings, mv/sec }\end{array}$} & \multicolumn{2}{|c|}{$\begin{array}{l}\mathrm{CO}_{2} \text { chamber } \\
\text { readings, mv/sec }\end{array}$} & \multirow{2}{*}{$\begin{array}{c}\phi \\
\text { calculated, } \\
\mathrm{n} / \mathrm{cm}^{2}-\mathrm{sec}\end{array}$} & \multirow{2}{*}{$\begin{array}{l}\text { Fraction } \\
\text { of MPD }\end{array}$} & \multirow{2}{*}{$\begin{array}{c}\gamma \\
\text { calculated, } \\
\mathrm{mr} / \mathrm{hr}\end{array}$} \\
\hline & & & Mrep/hr & Fraction of MPD & Gross & Net & Gross & Net & & & \\
\hline 2 & $\mathrm{I}-13$ & $\sim 50$ & $<0.1$ & & 1.339 & 0.678 & 2.273 & 1.612 & 2.90 & 0.26 & 0.13 \\
\hline 3 & $\mathrm{I}-16-17$ & $\sim 60$ & $\sim 0.1$ & $\sim 0.13$ & 1.507 & 0.846 & 3.043 & 2.382 & 8.09 & 0.27 & 0.20 \\
\hline 4 & $\begin{array}{l}\text { I-18-19 } \\
\quad \text { (near radiation } \\
\text { source safe) }\end{array}$ & $\sim 70$ & $<0.1$ & & 1.786 & 0.768 & 3.182 & 1.946 & 8.37 & 0.28 & 0.16 \\
\hline 5 & I-21-22 & $\sim 50$ & & & 1.241 & 0.223 & 2.348 & 1.113 & Negligible & & 0.09 \\
\hline 6 & $\mathrm{I}-24$ & 46 & & & 1.245 & 0.367 & 1.881 & 0.949 & 3.91 & 0.13 & 0.08 \\
\hline 6 & I-24 (no beam) & & & & 0.878 & & 0.932 & & & & \\
\hline
\end{tabular}




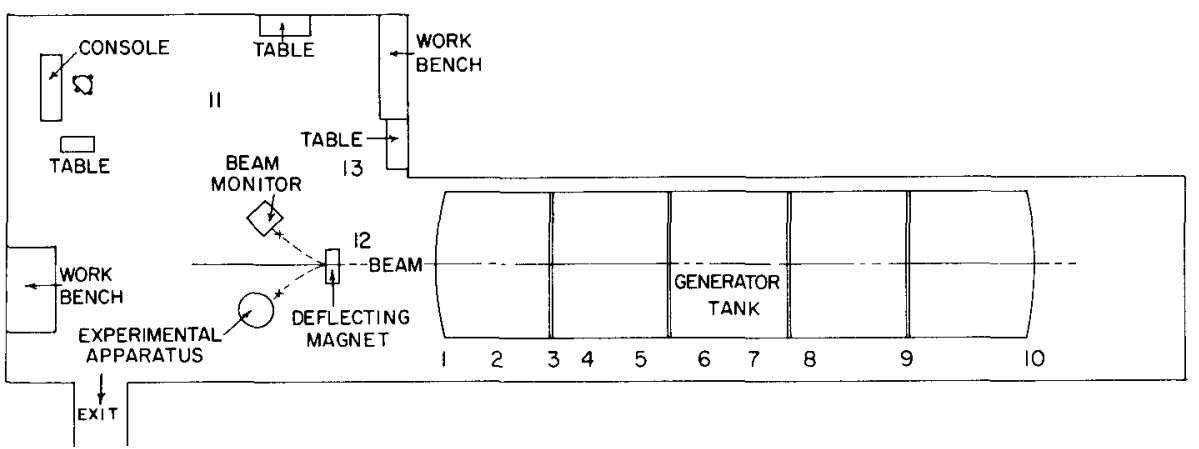

Fig. 17-State University of Iowa Van de Graaff generator layout, July 1955.

Table 17-STATE UNIVERSITY OF IOWA 5-MEV VAN DE GRAAFF (JULY 11, 1955)

(Operating Condition: 2-Mev Protons on Brass)

\begin{tabular}{|c|c|c|}
\hline Position & Instrument & Radiation level \\
\hline 1 & SIC-17C & $3 \mathrm{mr} / \mathrm{hr}$ \\
\hline 2 & $\mathrm{SIC}-17 \mathrm{C}$ & $8 \mathrm{mr} / \mathrm{hr}$ \\
\hline 3 & $\mathrm{SIC}-17 \mathrm{C}$ & $27 \mathrm{mr} / \mathrm{hr}$ \\
\hline 4 & $\mathrm{SIC}-17 \mathrm{C}$ & $65 \mathrm{mr} / \mathrm{hr}$ \\
\hline 5 & SIC-17C & $160 \mathrm{mr} / \mathrm{hr}$ \\
\hline 6 & $\mathrm{SIC}-17 \mathrm{C}$ & $105 \mathrm{mr} / \mathrm{hr}$ \\
\hline $5-6$ & SIC-17C & $270 \mathrm{mr} / \mathrm{hr}$ (max.) \\
\hline 7 & $\mathrm{SIC}-17 \mathrm{C}$ & $80 \mathrm{mr} / \mathrm{hr}$ \\
\hline 8 & SIC-17C & $7 \mathrm{mr} / \mathrm{hr}$ \\
\hline 9 & $\mathrm{SIC}-17 \mathrm{C}$ & $\sim 2 \mathrm{mr} / \mathrm{hr}$ \\
\hline 10 & $\mathrm{SIC}-17 \mathrm{C}$ & $\sim 1 \mathrm{mr} / \mathrm{hr}$ \\
\hline $11-12(\sim 1 \mathrm{ft}$ & $\mathrm{BF}_{3}$ L.C.* & $<1 \mathrm{n} / \mathrm{cm}^{2}-\mathrm{sec}$ \\
\hline from target) & 5-in. $\mathrm{ZnS} \dagger$ & $\sim 0 \mathrm{n} / \mathrm{cm}^{2}-\mathrm{sec}$ \\
\hline $13(\sim 4 \mathrm{ft}$ from & $\mathrm{BF}_{3}$ L.C.* & $<1 \mathrm{n} / \mathrm{cm}^{2}-\mathrm{sec}$ \\
\hline target) & $\mathrm{BF}_{3}$ L.C.* (no Cd) & $<1 \mathrm{n} / \mathrm{cm}^{2}-\mathrm{sec}$ \\
\hline 4 (repeated) & $\mathrm{SIC}-17 \mathrm{C}$ & $37 \mathrm{mr} / \mathrm{hr}$ \\
\hline & $\mathrm{CO}_{2}$ & $\gamma=40 \mathrm{mr} / \mathrm{hr}$ \\
\hline & $\mathrm{TE}$ & $\phi=0 \mathrm{n} / \mathrm{cm}^{2}-\mathrm{sec}$ \\
\hline
\end{tabular}

$* \mathrm{BF}_{3}$ long counter.

$\dagger \mathrm{ZnS}$ scintillation neutron counter with 5-in.-diameter phosphor.

Table 18. With $30 \mathrm{n} / \mathrm{cm}^{2}-\mathrm{sec}$ taken as the maximum permissible neutron flux for $40-\mathrm{hr}$ occupancy, the MPE rate is not approached, except in the immediate vicinity of the diffusion pump (position 7).

At position 9 levels were encountered without the cadmium and paraffin jackets which were several times the MPE rate in terms of Po-Be calibration, but this is attributable to a low flux of thermalized neutrons. The actual radiation level in terms of fast neutrons was only 15 or 20 per cent of the MPE. It is appropriate to point out that the 5-in. ZnS-Lucite scintillation detector gave barely perceptible readings at this location, which suggests a degraded spectrum (i.e., neutrons below the approximate $500-\mathrm{kev}$ cutoff of the scintillation detector).

The following suggestions were offered:

1. Under operating conditions of the survey, radiation levels at both accelerators were very low with no indication that shielding in any location was inadequate.

2. A sign indicating a radiation hazard at the end of the Van de Graaff tank tied to a rope barrier would be appropriate. 
Table 18-STATE UNIVERSITY OF IOWA 400-KEV

COCKCROFT-WALTON GENERATOR (ROOM 23)

(Operating Condition: 400-kev Deuterons on Deuterium; 50- to 100- $\mu \mathrm{a}$ Beam)

\begin{tabular}{|c|c|c|}
\hline Position & Instrument & Neutron level \\
\hline 1 (NE corner) & $\mathrm{BF}_{3}$ L.C. (background) & 0 \\
\hline 2 (console) & $\begin{array}{l}\mathrm{BF}_{3} \text { L.C. } \\
\text { 5-in. } \mathrm{ZnS}\end{array}$ & $\begin{array}{l}<1 \mathrm{n} / \mathrm{cm}^{2}-\mathrm{sec} \\
\sim 0\end{array}$ \\
\hline $\begin{array}{l}3 \text { (in front of } \\
\text { water shielding) }\end{array}$ & $\begin{array}{l}\mathrm{BF}_{3} \text { L.C. } \\
\text { 5-in. } \mathrm{ZnS}\end{array}$ & $\begin{array}{l}<1 \mathrm{n} / \mathrm{cm}^{2}-\mathrm{sec} \\
\sim 0\end{array}$ \\
\hline 4 & $\mathrm{BF}_{3}$ L.C. & $4-8 \mathrm{n} / \mathrm{cm}^{2}-\mathrm{sec}$ \\
\hline 5 & $\begin{array}{l}\mathrm{BF}_{3} \text { L.C. } \\
\mathrm{BF}_{3} \text { L.C. (no Cd) } \\
\text { 5-in. } \mathrm{ZnS}\end{array}$ & $\begin{array}{l}4-8 \mathrm{n} / \mathrm{cm}^{2}-\mathrm{sec} \\
5-9 \mathrm{n} / \mathrm{cm}^{2}-\mathrm{sec} \\
\sim 0\end{array}$ \\
\hline 6 & $\begin{array}{l}\mathrm{BF}_{3} \mathrm{~L} . \mathrm{C} . \\
\text { 5-in. } \mathrm{ZnS}\end{array}$ & $\begin{array}{l}5-9 \mathrm{n} / \mathrm{cm}^{2}-\mathrm{sec} \\
\sim 0\end{array}$ \\
\hline 7 & $\begin{array}{l}\mathrm{BF}_{3} \text { L.C. } \\
\text { 5-in. ZnS }\end{array}$ & $\begin{array}{l}9-16 \mathrm{n} / \mathrm{cm}-\mathrm{sec} \\
\sim 0\end{array}$ \\
\hline 8 & $\begin{array}{l}\mathrm{BF}_{3} \text { L.C. } \\
\mathrm{BF}_{3} \text { L.C. (no Cd) } \\
\mathrm{BF}_{3} \text { L.C. (no Cd, } \\
\text { no paraffin) }\end{array}$ & $\begin{array}{l}7-15 \mathrm{n} / \mathrm{cm}^{2}-\mathrm{sec} \\
7-15 \mathrm{n} / \mathrm{cm}^{2}-\mathrm{sec} \\
20-45 \mathrm{n} / \mathrm{cm}^{2}-\mathrm{sec}\end{array}$ \\
\hline $\begin{array}{l}9 \\
9 a\end{array}$ & $\begin{array}{l}\mathrm{BF}_{3} \text { L.C. } \\
\mathrm{BF}_{3} \text { L.C. (no Cd, } \\
\text { no paraffin) }\end{array}$ & $\begin{array}{l}4-6 \mathrm{n} / \mathrm{cm}^{2}-\mathrm{sec} \\
60-160 \mathrm{n} / \mathrm{cm}^{2}-\mathrm{sec}\end{array}$ \\
\hline & 5-in. $\mathrm{ZnS}$ & $\sim 0$ \\
\hline $\begin{array}{l}\text { On platform inside } \\
\text { vault } \sim 5 \mathrm{ft} \text { from } \\
\text { electrode }\end{array}$ & $\begin{array}{l}\text { SIC-17C } \\
\text { 5-in. ZnS }\end{array}$ & $\begin{array}{l}10-12 \mathrm{mr} / \mathrm{hr} \\
\sim 0\end{array}$ \\
\hline
\end{tabular}

Fig. 18- State University of Iowa Cockcroft-Walton accelerator layout, July 1955 . 
3. Adoption of a fast neutron film badge packet such as that offered by the BNL off-site monitoring service was recommended for persons engaged in work at both accelerators.

4. Should beam operation conditions change substantially at either accelerator, e.g., highenergy deuterons on deuterium at the Van de Graaff or deuterons on tritium at the CockcroftWalton, a reexamination of the stray radiation problem wculd be necessary.

\subsection{University of Minnesota}

The evaluation of radiation levels at the proton Inear accelerator was carried out in July 1955. The full energy of the proton beam ( $68 \mathrm{Mev}$ ) had not yet been achieved at the time of these measurements; therefore, the results are applicable to an interim condition with two of the three accelerating tubes in operation and a proton beam of $40 \mathrm{Mev}$. The $\mathrm{r}-\mathrm{f}$ was $202.55 \mathrm{Mc}$. There were 15 pulses/sec with a pulse duration of about $200 \mu \mathrm{sec}$. During the morning of July 13 the beam current was approximately $10^{-9} \mathrm{amp}$ at the aluminum target. By the evening of July 14 the beam had increased to about $7 \times 10^{-9}$, approximately $10^{-8} \mathrm{amp}$.

The inside measurements are summarized in Table 19. Locations are marked on the floor plan (Fig. 19). The entries given in each column are described below.

Column 1: The gamma radiation level with the beam on as determined from the equations ( $\mathrm{TE}-\mathrm{CO}_{2}$ calibration equations).

Column 2: The neutron flux (Po-Be equivalent) as determined from the equations.

Column 3: The gamma-radiation level with the $r-f$ on but no beam as measured by the graphite $-\mathrm{CO}_{2}$ chamber.

Table 19 -SUMMARY OF INSIDE MEASUREMENTS AT UNIVERSITY OF MINNESOTA LINAC (JULY 1955)

\begin{tabular}{|c|c|c|c|c|c|c|c|}
\hline Position & $\begin{array}{c}(1) \\
\gamma \text { beam, } \\
\mathrm{mr} / \mathrm{hr}\end{array}$ & $\begin{array}{c}\text { (2) } \\
\phi \text { beam, } \\
\mathrm{n} / \mathrm{cm}^{2}-\mathrm{sec}\end{array}$ & $\begin{array}{c}(3) \\
\mathrm{CO}_{2} \\
\gamma \mathrm{r}-\mathrm{f} \\
\mathrm{mr} / \mathrm{hr}\end{array}$ & $\begin{array}{c}\text { (4) } \\
\mathrm{TE} \\
\gamma \mathrm{r}-\mathrm{f} \\
\mathrm{mr} / \mathrm{hr}\end{array}$ & $\begin{array}{c}\text { (5) } \\
\mathrm{BF}_{3} \mathrm{~L} \text {.C. } \\
\mathrm{n} / \mathrm{cm}^{2}-\mathrm{sec}\end{array}$ & $\begin{array}{c}(6) \\
\text { SIC-17C } \\
\text { beam, } \\
\mathrm{mr} / \mathrm{hr}\end{array}$ & $\begin{array}{c}(7) \\
\text { SIC-17C } \\
\mathrm{r}-\mathrm{f}, \\
\mathrm{mr} / \mathrm{hr}\end{array}$ \\
\hline 1 & 0.1 & $\sim 0$ & & & $<1$ & & \\
\hline 2 & 1.22 & 17.4 & 0.79 & 1.06 & $<1$ & & \\
\hline 3 & 29.6 & $\sim 0$ & 22.2 & 21.2 & $32-78$ & 38 & 26 \\
\hline 4 & 934 & & & 934 & $125-320$ & & \\
\hline 5 & 17.8 & 0.7 & 19.1 & 17.0 & $7-14$ & & \\
\hline 6 & 0.41 & $\sim 0$ & & & $<1$ & & \\
\hline 7 & 1.53 & 22 & & & $1-1.5$ & $1-2$ & \\
\hline 8 & 13.4 & 80.1 & & & $12-26$ & 14 & \\
\hline
\end{tabular}

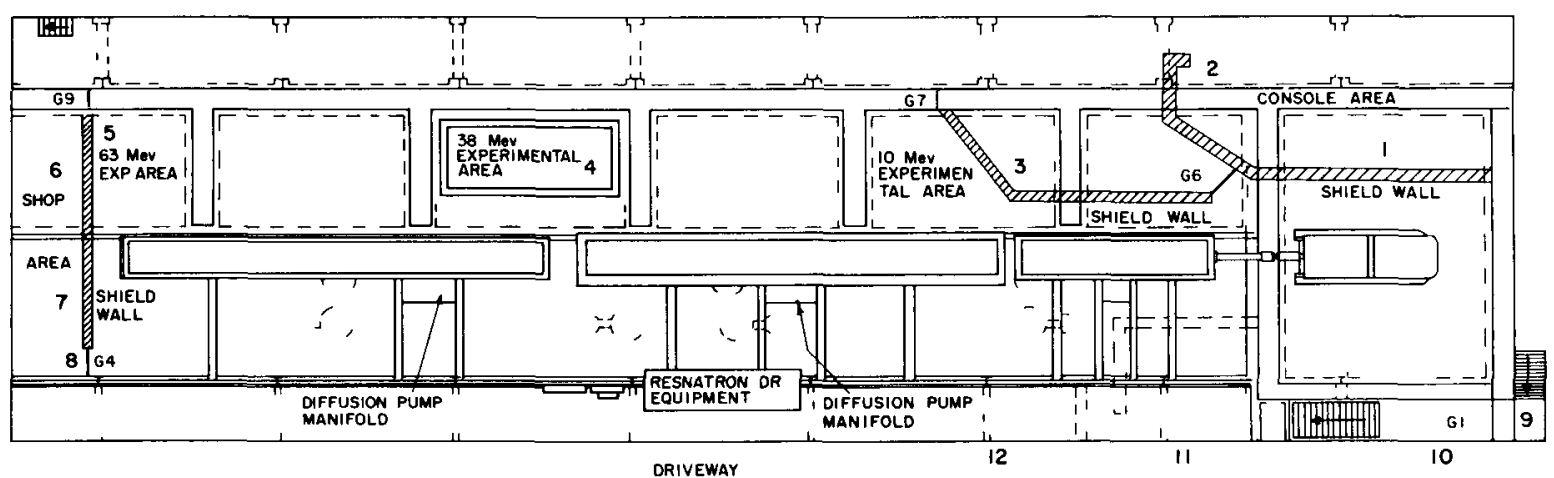

Fig. 19-University of Minnesota linear accelerator layout. 
Column 4: The gamma-radiation level with the $r-f$ on but no beam as measured by the tissue equivalent ionization chamber.

Column 5: The fast neutron level as measured by the $\mathrm{BF}_{3}$ long counter in terms of Po-Be equivalent.

Column 6: The SIC-17C ionization chamber reading with the beam on.

Column 7: The SIC-17C ionization chamber with only the $r-f$ on.

Measurements made in nearby office and lavatory areas indicated that insignificant radiation levels were present. Measurements made outside the accelerator building with a Juno survey meter are shown in Table 20.

A perusal of the measurements lead to the following observations:

1. In no occupied location does the fast neutron level exceed the gamma-ray level in terms of rem, that is to say, in terms of personnel hazard.

2. The only regularly occupied area where radiation levels were consistently high in terms of the MPE rate was behind the shield of the 10-Mev experimental station (Fig. 19).

3. In regularly occupied areas, i.e., the console and the shop area (68-Mev experimental area), radiation levels were consistently low, except outside gate 4 (position 8, Fig. 19).

4. In the driveway on the south wall of the building (Fig. 19), an occasionally occupied area, levels up to $1 \mathrm{r} / \mathrm{hr}$ were encountered. The prevailing level in this driveway behind the shield was somewhere between one and three times the MPE rate.

Table 20-SUMMARY OF OUTSIDE MEASUREMENTS AT UNIVERSITY OF MINNESOTA LINAC (JULY 1955)

\begin{tabular}{|c|c|c|}
\hline Description* & & $\begin{array}{l}\mathrm{SIC}-17 \mathrm{C} \\
\mathrm{mr} / \mathrm{hr}\end{array}$ \\
\hline Main door (location 9) & 5 & \\
\hline Between 9 and first drainpipe (location 10) & 3 & \\
\hline First drainpipe (location 11 ) & 3.5 & \\
\hline $\begin{array}{l}\text { Between first and second drainpipes } \\
\text { (location 12) }\end{array}$ & 5.0 & \\
\hline Second drainpipe & \multicolumn{2}{|c|}{5.5 (shield) } \\
\hline Between second and third drainpipes & $\begin{array}{r}900 \\
21 \\
330 \\
15 \\
450 \\
18.5\end{array}$ & $\begin{array}{l}\text { (above shield) } \\
\text { (shield) } \\
\text { (above shield) } \\
\text { (shield) } \\
\text { (above shield) } \\
\text { (shield) }\end{array}$ \\
\hline Third drainpipe & $\begin{array}{r}370 \\
15 \\
40\end{array}$ & $\begin{array}{l}\text { (above shield) } \\
\text { (shield) } \\
\text { (fence) }\end{array}$ \\
\hline Between third and fourth drainpipes & $\begin{array}{r}100 \\
7\end{array}$ & $\begin{array}{l}\text { (above shield) } \\
\text { (shield) }\end{array}$ \\
\hline Between fourth and fifth drainpipes & \multicolumn{2}{|c|}{10.5 (shield) } \\
\hline Fifth drainpipe & $\begin{array}{r}15 \\
6\end{array}$ & $\begin{array}{l}\text { (above shield) } \\
\text { (shield) }\end{array}$ \\
\hline Center of building near railroad tracks & \multicolumn{2}{|c|}{55} \\
\hline Along track & 150 & (max. level) \\
\hline Main door & \multicolumn{2}{|l|}{5} \\
\hline Approximately $12 \mathrm{ft}$ from end of building & \multicolumn{2}{|l|}{3} \\
\hline Approximately $40 \mathrm{ft}$ from end of building & \multicolumn{2}{|l|}{5.5} \\
\hline Between second and third drainpipes & \multicolumn{2}{|l|}{11.5} \\
\hline Third drainpipe above shield & \multicolumn{2}{|l|}{16} \\
\hline Between third and fourth drainpipes & \multicolumn{2}{|l|}{8.5} \\
\hline
\end{tabular}

* See Fig. 19. 
5. Levels on the adjoining railroad tracks outside the building ranged up to $150 \mathrm{mr} / \mathrm{hr}$, something of the order of 20 times the MPE rate.

6. In general, the gamma levels were essentially independent of whether the proton beam was on or not, i.e., they depended essentially on the $r-f$.

The following recommendations were discussed with members of the University of Minnesota Occupational Health Service at a critique following the survey.

1. The utility or deficiencies of the interlock system will become apparent with experience. With this system the area is cleared by the operator making a circuit of the accelerator area and closing the gates behind him after physically inspecting locations and ascertaining that no personnel are present. The deficiency in this arrangement is that it allows for no lapse of judgment nor failure of observation on the part of the operator. The authors are somewhat more favorably disposed toward the more cumbersome, but more reliable, system by which one key can operate one gate and this key must be back in position at the console before the machine can be energized.

2. Although the neutron levels encountered during these measurements were low, it is recommended that personnel actively engaged in the operation of the accelerator or in experimental work associated with it avail themselves of a fast neutron packet as well as a betagamma film badge. Such a packet is available from BNL as part of its off-site monitoring service.

3. The posting of two or three warning signs along the driveway cautioning against loitering because of the high radiation levels would probably not be inappropriate.

4. It is anticipated that the radiation profile will experience considerable change when the third accelerator tube is in operation and the full energy of the accelerator is achieved. It is recommended that a detailed survey be performed once again at that time.

\subsection{Purdue University}

(a) Cyclotron. The Purdue cyclotron is located in the basement of the physics building. The layout shown in Fig. 20 is somewhat obsolete since the cyclotron has been reoriented and a water shield has been installed at the foot of the stairs (location 7) near the external target area. The locations of the measurements are substantially the same as in the diagram. A driveway and loading platform are located to the right of the layout at ground level near the control room. A lecture hall is located above the cyclotron proper. The general direction of the beam is toward the driveway and upward. Areas on other sides of the cyclotron were well protected by the permanent shielding.

During the survey there were three modes of cyclotron operation:

1. 10-Mev deuterons bombarded an external beryllium target to produce neutrons up to about $14 \mathrm{Mev}$ (Table 21).

2. The $10-\mathrm{Mev}$ deuterons were not removed outside the vault; this was the "no magnet," or internal beam condition (Table 21).

3. An external beam of $20-\mathrm{Mev}$ alpha particles was produced. Actually, this condition was said to represent a more typical kind of operation than the others (Table 22).

Table 21 summarizes the radiation levels measured during the condition of $10-\mathrm{Mev}$ deuterons on an external beryllium target. The $x$-ray levels at the locations noted appear to be of little consequence; however, at location 7 the maximum permissible level for a $40-\mathrm{hr}$ week, neglecting neutrons, was exceeded by about 40 per cent.

Four estimates of neutron fluxes are given for each location on the main floor: $\phi$ from the $\mathrm{BF}_{3}$ and $\mathrm{CO}_{2}$ chamber measurements, fluxes from the $\mathrm{ZnS}$ and fast neutron dosimeter measurements, and the thermal flux. The fact that the fluxes based on ionization chamber measurements are higher than the fluxes obtained with the ZnS-Lucite scintillation counter (SBX-21A) and the fast neutron dosimeter (SPC-6A) by large factors was to be expected. The calculated $\phi$ 's are the equivalent Po-Be fluxes and include neutrons of fairly low energies. On the other hand, the ZnS-Lucite counter has a high low-energy cutoff, believed to be about $0.4 \mathrm{Mev}$. Similarly, the fast neutron dosimeter responds only to neutrons above about $0.2 \mathrm{Mev}$. Thus, in a sense, the ionization chambers overestimated the fast neutron fluxes by measuring the intermediate energy neutrons.

Independent measurements with the $\mathrm{BF}_{3}$ ionization chamber support this opinion. Table 23 summarizes readings taken with the bare $\mathrm{BF}_{3}$ chamber, with the chamber surrounded by a 


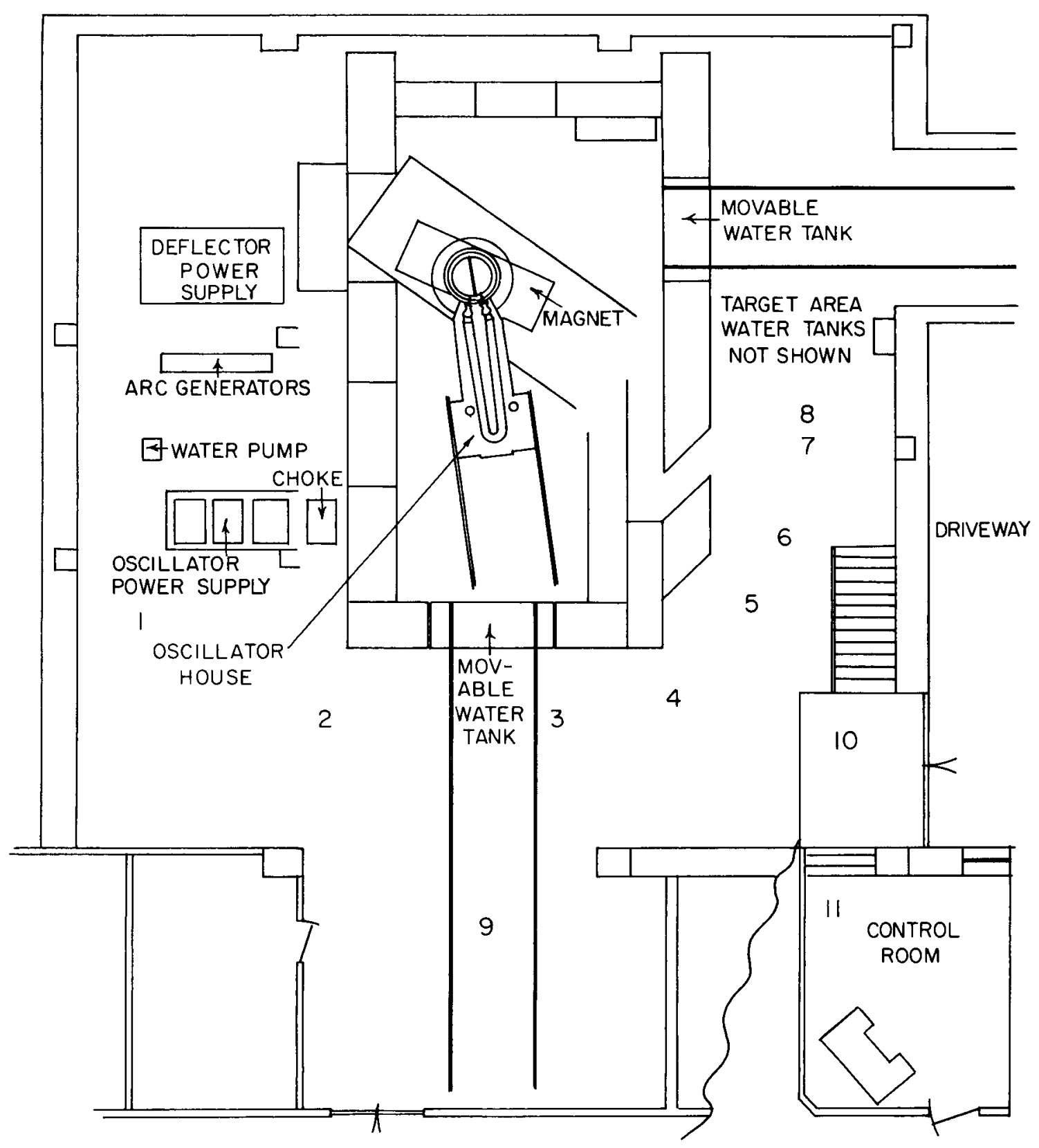

Fig. 20-Purdue University cyclotron layout (not to scale). 
Table 21-PURDUE UNIVERSITY CYCLOTRON (OCT. 3-4, 1955)

[Operating Condition: $10-\mathrm{Mev} \mathrm{H}^{2}$ on $\mathrm{Be}^{9}$ (External); Internal Beam $=5$ to $8 \mu \mathrm{a}$; External Beam $\cong 0.6 \mu \mathrm{a}$ ]

\begin{tabular}{|c|c|c|c|c|c|c|c|c|c|c|}
\hline Location & Description & $\begin{array}{c}\gamma \\
\mathrm{mr} / \mathrm{hr}\end{array}$ & $\begin{array}{c}\phi, \\
\mathrm{n} / \mathrm{cm}^{2}-\mathrm{sec}\end{array}$ & $\begin{array}{c}\text { Tissue dose } \\
\text { Calc. }\end{array}$ & $\begin{array}{l}\text { rate, mrep/hr } \\
\text { Obs. }(\mathrm{R})^{*}\end{array}$ & $\begin{array}{c}\text { Ratio } \\
\text { TE } \\
\text { (obs./calc.) }\end{array}$ & $\begin{array}{l}\text { Fraction } \\
\text { of MPD } \\
\text { (neutrons) }\end{array}$ & $\begin{array}{l}\text { Thermal } \\
\text { flux, } \\
\mathrm{n} / \mathrm{cm}^{2}-\mathrm{sec}\end{array}$ & $\begin{array}{c}\text { Fast flux, } \\
\text { ZnS }\end{array}$ & $\begin{array}{l}1 / \mathrm{cm}^{2}-\mathrm{sec} \\
\text { FND }\end{array}$ \\
\hline 1 & $\begin{array}{l}\text { Near oscillator power } \\
\text { supply }\end{array}$ & 1.67 & 118.2 & 3.35 & 2.29 & 0.68 & 4.58 & $\sim 15$ & & \\
\hline 2 & Corner of shield & 1.05 & 78.8 & 2.17 & 1.22 & 0.56 & 2.44 & $\sim 15$ & $<10$ & \\
\hline 3 & Work area & 3.59 & 453.9 & 10.0 & 5.39 & 0.54 & 10.8 & $>270$ & 35 & \\
\hline 4 & Corner of shield & 1.32 & 398.8 & 6.98 & 2.53 & 0.36 & 5.06 & $\sim 270$ & $\sim 16$ & \\
\hline 5 & Near stairs & 2.51 & 531.2 & 10.1 & 4.20 & 0.42 & 8.40 & $>270$ & 31 & \\
\hline 6 & Foot of stairs & 6.04 & 527.8 & 13.5 & 9.69 & 0.72 & 19.4 & $>270$ & 50 & \\
\hline 7 & $\begin{array}{l}\text { Near entrance to } \\
\text { external target }\end{array}$ & 8.89 & 982.4 & 22.8 & 14.9 & 0.65 & 29.8 & $<270$ & 150 & 198 \\
\hline 8 & Top of water shield & & & & & & & & $>300$ & 705 \\
\hline 9 & $\begin{array}{l}\text { Door to lower level } \\
\text { corridor (near } \\
\text { Ra-Be safe) }\end{array}$ & 0.66 & N.D. & & & & & & $<10$ & \\
\hline 6 & Repeat on Oct. 4 & 4.06 & 640.2 & 13.2 & 9.02 & 0.68 & 18.0 & 245 & 35 & 146 \\
\hline 6 & $\begin{array}{l}\text { No external beam, } \\
\text { no magnet }\end{array}$ & 2.33 & 158.0 & 4.80 & 2.34 & 0.49 & 4.68 & 125 & $<10$ & 42 \\
\hline 10 & $\begin{array}{l}\text { Head of stairs to } \\
\text { control room } \\
\text { (no external beam) }\end{array}$ & & & & & & & 98 & $<10$ & 14 \\
\hline 10 & $\begin{array}{l}\text { Head of stairs } \\
\text { to control room } \\
\text { (external beam) }\end{array}$ & & & & & & & 205 & 32 & 106 \\
\hline \multirow[t]{5}{*}{11} & $\begin{array}{l}\text { Control room } \\
\text { (external beam) }\end{array}$ & & & & & & & 65 & $<10$ & 26 \\
\hline & Lecture hall No. 103 & & & & & & & & & 17 \\
\hline & $\begin{array}{r}\text { Outside room } 103 \\
\text { (external beam) }\end{array}$ & & & & & & & & $<10$ & \\
\hline & $\begin{array}{l}\text { Left window near exit } \\
\text { (external beam) }\end{array}$ & & & & & & & 270 & $\sim 10$ & \\
\hline & $\begin{array}{l}\text { Right window near exit } \\
\text { (waist level, external } \\
\text { beam) }\end{array}$ & & & & & & & $>\mathbf{2 7 0}$ & 80 & 293 \\
\hline
\end{tabular}


Table $21-$ (Continued)

\begin{tabular}{|c|c|c|c|c|c|c|c|c|c|c|}
\hline Location & Description & $\begin{array}{c}\gamma \\
\mathrm{mr} / \mathrm{hr}\end{array}$ & $\begin{array}{c}\phi, \\
\mathrm{n} / \mathrm{cm}^{2}-\mathrm{sec}\end{array}$ & $\begin{array}{c}\text { Tissue dose } \\
\text { Calc. }\end{array}$ & $\begin{array}{l}\text { rate, } \mathrm{mrep} / \mathrm{hr} \\
\text { Obs. }(\mathrm{R})^{*}\end{array}$ & $\begin{array}{l}\text { Ratio } \\
\text { TE } \\
\text { (obs./calc.) }\end{array}$ & $\begin{array}{l}\text { Fraction } \\
\text { of MPD } \\
\text { (neutrons) }\end{array}$ & $\begin{array}{l}\text { Thermal } \\
\text { flux, } \\
\mathrm{n} / \mathrm{cm}^{2}-\mathrm{sec}\end{array}$ & $\begin{array}{r}\text { Fast flux, } \\
\text { ZnS }\end{array}$ & $\begin{array}{l}\mathrm{n} / \mathrm{cm}^{2}-\mathrm{sec} \\
\text { FND }\end{array}$ \\
\hline & $\begin{array}{l}\text { Driveway, second window } \\
\text { from loading platform } \\
\text { (waist level, external } \\
\text { beam) }\end{array}$ & & & & & & & $>\mathbf{2 7 0}$ & 180 & 680 \\
\hline & $\begin{array}{l}\text { Driveway, first window } \\
\text { from loading platform } \\
\text { (waist level, external } \\
\text { beam) }\end{array}$ & & & & & & & $>270$ & 65 & 166 \\
\hline & Driveway, center & & & & & & & 92 & & \\
\hline
\end{tabular}

$* \mathrm{R}$, rate meter.

Table 22-PURDUE UNIVERSITY CYCLOTRON (OCT. 4, 1955)

(Operating Condition: 20-Mev He $e^{4}$ External Beam; Internal Beam $\cong 1 \mu \mathrm{a}$; External Beam $\cong 0.1 \mu \mathrm{a}$ )

\begin{tabular}{|c|c|c|c|c|c|c|c|c|c|c|}
\hline Location & Description & $\begin{array}{c}\gamma, \\
\mathrm{mr} / \mathrm{hr}\end{array}$ & $\begin{array}{c}\phi, \\
\mathrm{n} / \mathrm{cm}^{2}-\sec \end{array}$ & $\begin{array}{c}\text { Tissue dose } \\
\text { Calc. }\end{array}$ & $\begin{array}{l}\text { rate, } \mathrm{mrep} / \mathrm{hr} \\
\text { Obs. (I)* }\end{array}$ & $\begin{array}{c}\text { Ratio } \\
\text { TE } \\
\text { (obs./calc.) }\end{array}$ & $\begin{array}{l}\text { Fraction } \\
\text { of MPD } \\
\text { (neutron) }\end{array}$ & $\begin{array}{c}\text { Flux } \\
\mathrm{n} / \mathrm{cm}^{2}-\mathrm{sec}\end{array}$ & $\begin{array}{r}\text { Fast flux } \\
\text { ZnS }\end{array}$ & $\begin{array}{l}\mathrm{n} / \mathrm{cm}^{2}-\mathrm{sec} \\
\text { FND }\end{array}$ \\
\hline 2 & Corner of shield & 0.16 & 1.3 & 0.18 & 0.13 & 0.72 & 0.26 & $\sim 5$ & & \\
\hline 3 & Work area & 0.09 & 7.1 & 0.20 & 0.13 & 0.65 & 0.26 & $\sim 6$ & & \\
\hline 5 & Near stairs & 0.05 & 13.9 & 0.25 & 0.12 & 0.48 & 0.24 & $\sim 18$ & & \\
\hline \multirow[t]{2}{*}{7} & $\begin{array}{l}\text { Near entrance to external } \\
\text { target }\end{array}$ & 0.37 & 22.5 & 0.69 & 0.44 & 0.64 & 0.88 & 65 & & \\
\hline & Beam area & & & & & & & & $\sim 20$ & \\
\hline
\end{tabular}

* I, integrator. 
Table 23-SUMMARY OF $\mathrm{BF}_{3}$ IONIZATION CHAMBER

MEASUREMENTS FOR CYCLOTRON CONDITION IN TABLE 21

\begin{tabular}{|c|c|c|c|}
\hline Location & Instrument & & Reading \\
\hline \multirow[t]{3}{*}{1} & Bare & 510 & $\mathrm{mv}\left(10^{10} \mathrm{ohms}\right)$ \\
\hline & With polyethylene & 405 & \\
\hline & Polyethylene $+\mathrm{Cd}$ & 315 & \\
\hline \multirow[t]{3}{*}{2} & Bare & 430 & $\mathrm{mv}\left(10^{10}\right.$ ohms $)$ \\
\hline & With polyethylene & 260 & \\
\hline & Polyethylene $+\mathrm{Cd}$ & 210 & \\
\hline \multirow[t]{2}{*}{4} & Bare & 12 & $\mathrm{mv}\left(10^{8} \mathrm{ohms}\right)$ \\
\hline & With polyethylene & 10.5 & \\
\hline \multirow[t]{3}{*}{6} & Bare & 24.5 & $\mathrm{mv}\left(10^{8}\right.$ ohms $)$ \\
\hline & With polyethylene & 15 & \\
\hline & Polyethylene $+\mathrm{Cd}$ & 14 & \\
\hline
\end{tabular}

thickness of polyethylene which will give an optimum response to Po-Be neutrons, and with a cadmium metal sheet surrounding the entire assembly. In all cases the addition of polyethylene indicated that the attenuation of neutrons predominated over the thermalization process for this thickness of moderator. Thus the "average" energy of the stray neutrons was thought to be less than that of Po-Be neutrons. The reduced reading obtained by the addition of cadmium indicates the presence of thermal neutrons in all cases to some degree.

As expected, the neutron fluxes in locations 6 and 7 are quite high in terms of personnel occupancy; for example, the fast neutron dose rate (less than $0.2 \mathrm{Mev}$ ) in location 7 was about $3.1 \mathrm{mrep} / \mathrm{hr}$ on a first-collision basis $\left(198 \mathrm{n} / \mathrm{cm}^{2}-\mathrm{sec}\right)$. To this must be added high thermal and intermediate neutron fluxes as well as the $x$-ray level. The total tissue dose rate in location 7 (first-collision dose rate), as measured with the tissue equivalent chamber, is about $15 \mathrm{mrep} / \mathrm{hr}$ from all radiations.

The columns headed "Calculated TE" and "Observed TE" in Tables 21 and 22 are estimates of the total tissue dose rate. The first was calculated from the $\mathrm{BF}_{3}-\mathrm{CO}_{2}$ data, and the second was measured with the tissue equivalent (TE) chamber.

It is believed that the discrepancies between the predicted TE dose rates and the observed TE dose rates are attributable to the low sensitivity of the TE chamber to low-energy neutrons and the relatively high sensitivity of the $\mathrm{BF}_{3}$ chamber to these neutrons. The observed dose rates then are probably more direct estimates of the more biologically important neutron fluxes. Thus the column headed "Fraction of neutron MPD," which ignores the slight $x$-ray contribution, should be taken as a fairly good estimate of the potential radiation hazard.

The column headed "Ratio $T E$ " is the ratio of the observed to the predicted tissue dose rate. This ratio is unity for a mixed radiation field of radium gammas and Po-Be neutrons. A ratio less than 1 suggests the presence of low-energy neutrons, which are measured more efficiently by the $\mathrm{BF}_{3}$ chamber than by the $\mathrm{TE}$ chamber.

Survey meter measurements made in a nearby classroom (No. 103) and outside the cyclotron building are shown in Table 21. Low fast neutron levels were detected throughout the classroom during the worst operating condition, i.e., deuterons on an external beryllium target. As expected, levels outside the building, especially near the window, were uniformly high during the external beam condition since essentially no shielding exists in these places. Neutron fluxes in the driveway, although high near the windows, fell off fairly rapidly in the center of the driveway. The decrease can be attributed to the fact that the general direction of the neutrons is upward from the basement target area.

Table 22 summarizes the radiation levels in a few locations during the production of 20Mev alpha particles. X-ray levels were utterly insignificant. Although the evidence for the existence of neutrons is fairly conclusive, the estimates of $\phi$ reported seem to be high. The approximate ratio of the predicted tissue dose rate to the observed is about 2 . This can be explained by the presence of low-energy neutrons (Table 24). 
Measurements with the ZnS counter indicated insignificant levels of neutrons greater than $0.4 \mathrm{Mev}$, except in the target area where fluxes of the order of the maximum permissible were found.

It should be pointed out that the reduction of the $\mathrm{BF}_{3}$ ionization chamber readings by the addition of polyethylene may be due in part to low-energy $x$ rays, but the importance of this contribution is probably unimportant in view of the cadmium difference and survey meter measurements.

In general, the average energy of the stray neutrons is below that of Po-Be neutrons for the three modes of cyclotron operation surveyed. On the other hand, much of the neutron spectrum is above the cadmium resonance region, about $0.6 \mathrm{ev}$. Therefore, during deuteron acceleration the potential radiation problem suggested by the ionization chamber estimates of the neutron fluxes, $\phi$, is probably not as great as it would be if these neutrons were comparable to Po-Be neutrons. However, even if the average energy is conjectured to be as low as $0.1 \mathrm{Mev}$, the maximum permissible flux ${ }^{10}\left(200 \mathrm{n} / \mathrm{cm}^{2}-\mathrm{sec}\right.$ for $\left.40 \mathrm{hr}\right)$ is still exceeded by a factor of about 2.5 in location 6. The value of this fraction of maximum permissible flux is comparable to the fraction of observed fast neutron flux to the maximum permissible fast flux (2 Mev or greater) in this location. Thus neither portion of the spectrum can be regarded as the governing factor for safe operation in location 6 or, it seems, in other places. Finally, considering the significant $\mathrm{x}$-ray levels encountered in some places, and even the thermal neutron fluxes, the use of areas near locations 3, 4, 5, 6, and 7 for personnel occupancy for more than $2 \mathrm{hr} / \mathrm{wk}$ is never advisable.

It was recommended that the areas immediately outside the cyclotron vault and the external target area be excluded during the acceleration of deuterons and the door between the experimental area and corridor be locked by the operator prior to operation.

During the internal deuteron beam operation, neutron fluxes in locations 6, 7, and 10 were less than those encountered during external beam operation, but they still were a significant fraction of the maximum permissible flux. Thus the same problem of possible overexposure exists, although to a lesser degree. It was recommended that the areas in the vicinity of the cyclotron vault entrance be restricted to no more than 12-hr occupancy by any one person during a week for the internal deuteron beam condition. Areas near locations 1, 2, and 9 may be occupied somewhat longer, if necessary.

During the bombardment of external targets by deuterons, fairly high neutron levels existed in the driveway, especially adjacent to the building. The possibility exists then of persons being exposed to radiation without their knowing it. In the location near the second window from the loading platform, a person could conceivably receive his weekly maximum permissible dose in less than $7 \mathrm{hr}$. It was recommended that, if continuing deuteron bombardment of external targets is undertaken, the possibility of blocking the windows near the external target area should be investigated. If occasional deuteron bombardment is anticipated, radiation warning signs should be displayed.

Table 24-SUMMARY OF BF, IONIZATION CHAMBER MEASUREMENTS FOR CYCLOTRON CONDITION IN TABLE 22

\begin{tabular}{|c|c|c|c|}
\hline Location & Instrument & & Reading \\
\hline \multirow[t]{3}{*}{2} & Bare & \multicolumn{2}{|c|}{$38.5 \mathrm{mv} / \mathrm{sec}$} \\
\hline & With polyethylene & \multicolumn{2}{|c|}{30.2} \\
\hline & Polyethylene $+\mathrm{Cd}$ & \multicolumn{2}{|l|}{18.2} \\
\hline \multirow[t]{3}{*}{3} & Bare & & \\
\hline & With polyethylene & $\sim 35$ & $\mathrm{mv}\left(10^{10} \mathrm{ohms}\right)$ \\
\hline & Polyethylene $+\mathrm{Cd}$ & $\sim 30$ & \\
\hline \multirow[t]{3}{*}{5} & Bare & $\sim 62$ & $\mathrm{mv}\left(10^{10} \mathrm{ohms}\right)$ \\
\hline & With polyethylene & $\sim 47$ & \\
\hline & Polyethylene $+C d$ & $\sim 36$ & \\
\hline \multirow[t]{3}{*}{7} & Bare & 125 & $\mathrm{mv}\left(10^{10} \mathrm{ohms}\right)$ \\
\hline & With polyethylene & 85 & \\
\hline & Polyethylene $+\mathrm{Cd}$ & 60 & \\
\hline
\end{tabular}


Fast neutron fluxes are about equivalent to the maximum permissible flux near the doorway to the control room, location 11. It was recommended that the height of the water shield near the target area be increased to reduce stray radiation levels on the stairs leading to the control room.

No important radiation levels were encountered during the production of 20-Mev alpha particles, except inside the target area. It was suggested that this target area continue to be restricted in its use. The maximum fast neutron flux in classroom 103, above the cyclotron, was about $17 \mathrm{n} / \mathrm{cm}^{2}$-sec. Thermal fluxes were very low, only about 1 per cent of thermal neutron maximum permissible flux. It was suggested that the use of the lecture hall be restricted during the external deuteron mode of operation. In conclusion, the limitations of nuclear track film for monitoring personnel engaged in work at the Purdue cyclotron should be emphasized. It is unlikely that NTA film detects interactions involving neutrons with energies below about $0.5 \mathrm{Mev}$, especially for routine personnel monitoring purposes. The exposure of personnel to intermediate energy neutrons, which can be biologically important, cannot be established conclusively by the NTA film.

(b) Synchrotron. During the survey the synchrotron was pulsed 4 times/sec with a pulse duration of $100 \mu \mathrm{sec}$. The electron beam was estimated to be of the order of $10^{8}$ electrons/sec. The synchrotron group expressed special interest in radiation levels in the vicinity of the accelerator proper and the contribution of neutrons to the total radiation dose. Estimates of the radiation levels near the synchrotron were obtained by operating the electrometers with Esterline-Angus recorders. No interference with the survey instruments by the synchrotron was apparent.

Table 25 summarizes the radiation levels encountered on the date of the survey in terms of equivalent radium dose rates and Po-Be fluxes. Estimates of $\gamma$ and $\phi$ are based on the $\mathrm{BF}_{3}$ and $\mathrm{CO}_{2}$ ionization chamber measurements and their calibrations. In locations $\mathrm{F}, \mathrm{G}$, and $\mathrm{H}, \gamma$ and $\phi$ were obtained from the $\mathrm{TE}$ and $\mathrm{CO}_{2}$ measurements (Fig. 21). Survey rate meters were useless at this accelerator.

Estimates of the equivalent Po-Be neutron fluxes were uniformly low compared to the maximum permissible neutron flux.

$X$-ray levels were never more than one-half the equivalent radium gamma-ray MPD rate, although it was emphasized that the energies may not be comparable. Comparisons of the $\gamma$ value calculated from the calibration equations with the $\mathrm{x}$-ray dose obtained with the $\mathrm{CO}_{2}$ chamber alone, and even with the tissue dose rate (mrep/hr), indicate that $\mathrm{x}$ rays account for almost all the total radiation dose rate. The dose rates obtained with the TE chamber are believed to be the best measure of any potential radiation hazard. This dose rate is the one that

Table 25-PURDUE UNIVERSITY 300-MEV ELECTRON SYNCHROTRON (OCT. 5, 1955)

(Operating Condition: Beam Out South Port; Beam $\cong 10^{8}$ Electrons/sec;

One Sweep of $20 \mathrm{~K} \mu \mu \mathrm{f} / 12 \mathrm{~min} ; 4$ Pulses/sec; $1000 \mu \mathrm{sec} /$ pulse)

\begin{tabular}{|c|c|c|c|c|c|c|c|}
\hline Location & $\begin{array}{r}\gamma_{\mathrm{CO}_{2}} \\
\mathrm{mr} / \mathrm{hr}\end{array}$ & $\begin{array}{c}\gamma \\
\mathrm{mr} / \mathrm{hr}\end{array}$ & $\begin{array}{c}\phi, \\
\mathrm{n} / \mathrm{cm}^{2}-\mathrm{sec}\end{array}$ & $\begin{array}{r}\text { Tissue dose } \\
\text { Calc. }\end{array}$ & $\begin{array}{l}\text { rate, mrep/hr } \\
\text { Obs. }\end{array}$ & $\begin{array}{c}\text { Ratio } \\
\text { TE } \\
\text { (obs./calc.) }\end{array}$ & $\begin{array}{c}\text { Fraction } \\
\text { of } x \text {-ray } \\
\text { MPE } \\
\left(\gamma_{\mathrm{CO}_{2}} / 7.5\right)\end{array}$ \\
\hline A & 0.26 & 0.25 & 2.40 & 0.29 & 0.14 & 0.48 & 0.03 \\
\hline B & 0.50 & 0.49 & 4.49 & 0.56 & 1.96 & 3.50 & 0.07 \\
\hline $\mathrm{C}$ & 3.40 & 3.40 & 1.81 & 3.43 & 4.14 & 1.21 & 0.45 \\
\hline D & 0.41 & 0.40 & 1.11 & 0.43 & 0.51 & 1.19 & 0.05 \\
\hline $\mathbf{E}$ & 0.02 & 0.02 & 0.09 & 0.02 & 0 & & 0.003 \\
\hline $\begin{array}{c}F^{*} \text { (foot of } \\
\text { stairs) }\end{array}$ & 1.73 & 1.73 & 0 & 1.73 & 1.67 & 0.97 & 0.23 \\
\hline $\begin{array}{c}\mathrm{G}^{*} \text { (center } \\
\text { vault) }\end{array}$ & 9.30 & 9.45 & 0 & & 7.40 & & 1.24 \\
\hline $\mathrm{H}^{*}$ (oscilloscope) & 56.48 & 58.64 & 0 & & 28.64 & & 7.53 \\
\hline
\end{tabular}

* TE and $\mathrm{CO}_{2}$ chambers only. 


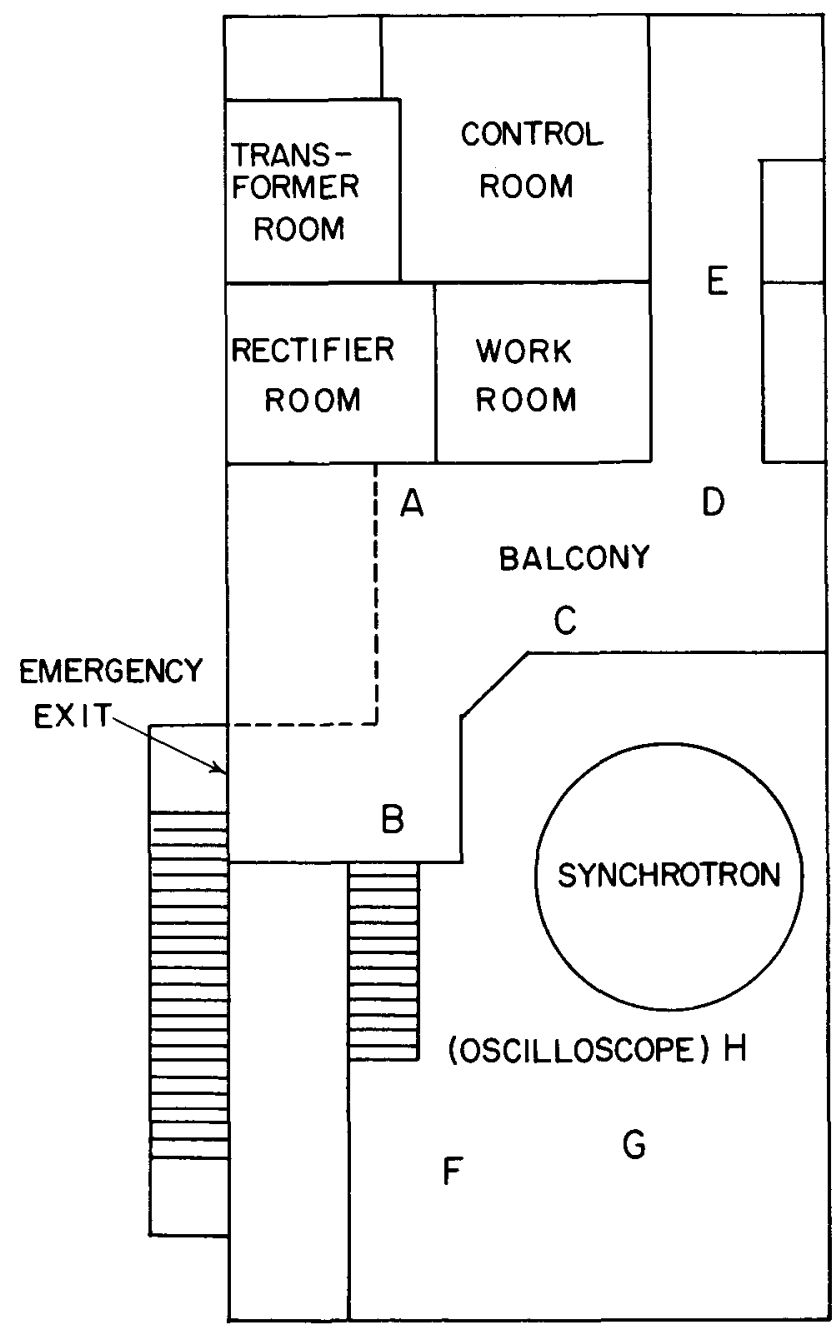

Fig. 21-Purdue University synchrotron layout (not to exact scale).

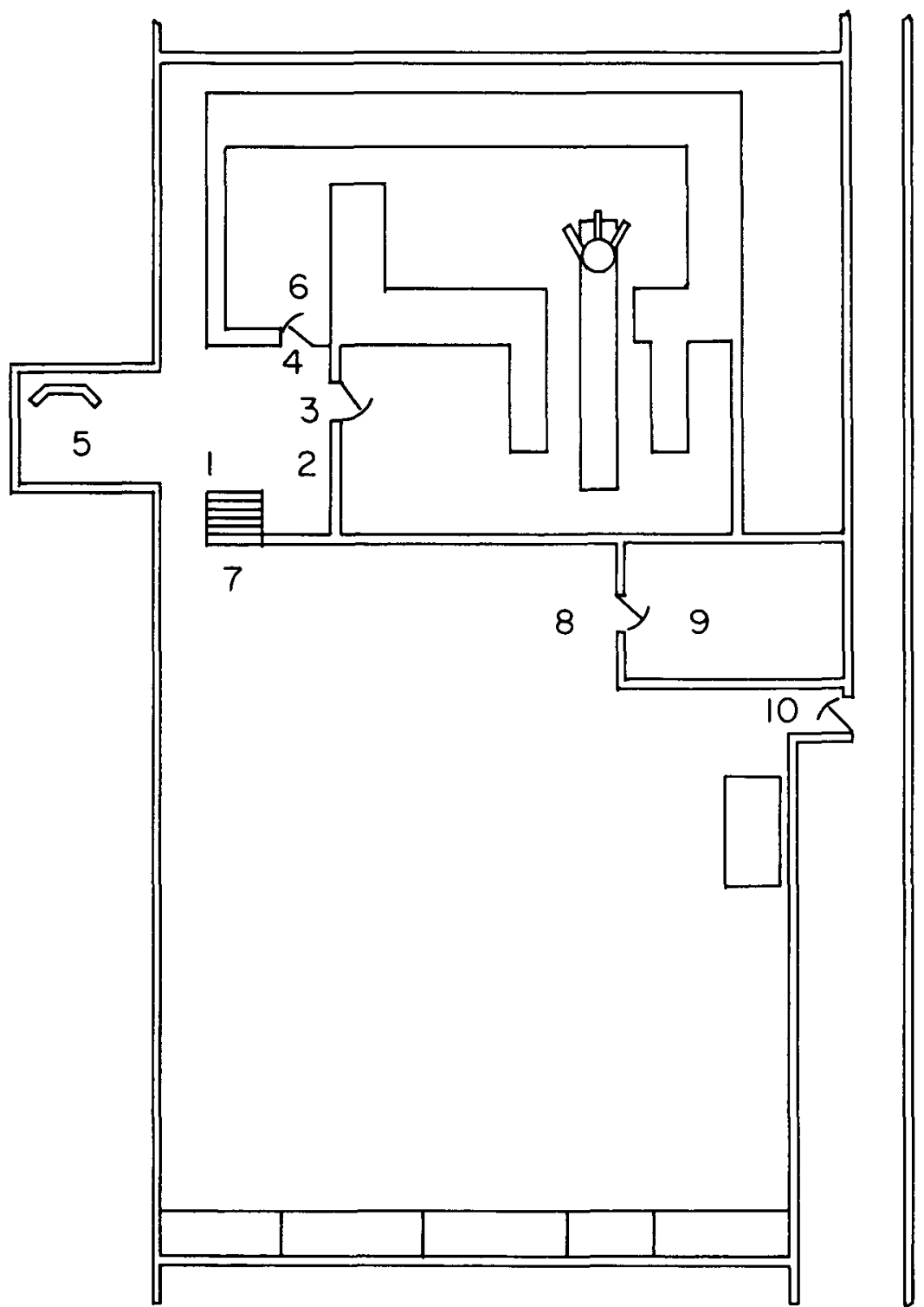

Fig. 22-Purdue University linear electron accelerator layout (not to scale). 
occurs presumably at a depth of $1 / 4$ in. in tissue (the chamber wall is $1 / 4$ in. thick), although the dose rate may be different at more biologically significant depths, e.g., $7 \mathrm{mg} / \mathrm{cm}^{2}$ for the skin and $5 \mathrm{~cm}$ for the blood-forming organs. ${ }^{20} \mathrm{~A}$ measure of hazard then is the observed TE dose rate divided by $7.5 \mathrm{mrep} / \mathrm{hr}$. The discrepancy of a factor of about 2 between the dose rate measurement with the $\mathrm{CO}_{2}$ chamber and that with the $\mathrm{TE}$ chamber in location $\mathrm{H}$ is unexplained. It was believed that the higher estimate should be used in predicting possible personnel exposure. Of course, this does not imply that occupancy of location $\mathrm{H}$ should be permitted routinely.

Measurements with and without cadmium over the $\mathrm{BF}_{3}$ chamber failed to indicate the presence of thermal neutrons.

No special recommendations appeared necessary regarding personnel occupancy of the balcony and approaches to the balcony from the control room. During the survey radiation levels near the synchrotron proper, reported in terms of radium dose rate, were in excess of maximum permissible levels.

(c) Linear Accelerator. During the survey the linear accelerator produced about 5.5-Mev electrons and no intentional $x$ rays. The pulse rate was $120 / \mathrm{sec}$ with a $1-\mu \mathrm{sec}$ duration. The beam current during a pulse was about $10 \mathrm{ma}$, the average beam current being about $1 \mu \mathrm{a}$. This condition was understood to be fairly typical of recent linear accelerator operations.

Estimates of extraneous $x$-ray levels were obtained in selected locations in rooms adjoining the accelerator. Estimates of neutron fluxes were made and found to be negligible everywhere.

X-ray levels were everywhere below the MPD rate except (1) in the control room, locations 3 and 4, Fig. 22, and (2) in the stock room, location 9.

Table 26 summarizes the estimates of the $x$-ray levels. The last column lists the fractions of the MPD rate $(7.50 \mathrm{mr} / \mathrm{hr})$ for $40 \mathrm{hr} / \mathrm{wk}$, using the observed TE dose rate.

If the accelerator is operated for $40 \mathrm{hr} / \mathrm{wk}$, the use of locations 3,4 , and 8 should be restricted or at least posted with radiation signs. Although the level at location 11 was below the maximum permissible for radiation workers, it is desirable to keep levels in areas occupied by uninformed persons to as low a level as possible. The possibility of installing a small supplementary shield inside the vault to reduce the level in the corridor should be investigated. It is conjectured that a fraction of an inch of lead, or its equivalent, should reduce the dose rate by a factor of 2 or more.

If the linear accelerator is operated less than $20 \mathrm{hr} /$ wk on the average, all levels should be less than $7.50 \mathrm{mr} / \mathrm{hr}$ unless a higher beam current is achieved. If $\mathrm{x}$-ray production is contemplated, an additional radiation survey would certainly be indicated.

In any case the occupancy times should be adjusted according to the personnel film badge results. It is advisable to keep personnel exposures to some value below $300 \mathrm{mr} / \mathrm{wk}$.

\subsection{University of Illinois}

(a) Cyclotron. Measurements of stray radiation at the nlinois cyclotron were made under two beam conditions: an external beam of $10-\mathrm{Mev}$ deuterons on a carbon target (Table 27) and an internal beam of $10-\mathrm{Mev}$ deuterons (Table 28). The cyclotron is located in a separate building near the University campus. Figure 23 is a view of the work area near location 5 on the floor plan (Fig. 24).

The area directly to the east of the accelerator experienced levels up to five times the MPD rate* (locations 1, 2, 3, 7, and 8). Levels in the neighborhood of the photocell interlock (location 4) received substantially higher dose rates, ranging up to 34 times the MPD.

Those areas directly behind the shielding (locations 9 and 10), including the area next to the $\mathrm{Ra}-\mathrm{Be}$ storage room (location 8), were the only areas where measurements indicated dose rates less than the maximum permissible under this beam condition.

Measurements made in the machine shop (locations 11 and 12) indicated radiation levels from two to five times the MPD rate.

*All references to MPD rates in Tables 27 to 31 refer to that for full-time (40-hr) occupancy. 
Table 26-PURDUE UNIVERSITY LINEAR ACCELERATOR (OCT. 5, 1955)

[Operating Condition 5.5-Mev Electrons (Al), 120 Pulses/sec of $1-\mu \mathrm{sec}$

Duration, $10 \mathrm{ma} /$ pulse, Average Beam $=1 \mu \mathrm{a}$ ]

\begin{tabular}{|c|c|c|c|c|c|c|c|c|}
\hline Location & Description & $\begin{array}{c}\gamma \\
\mathrm{SIC}-17 \mathrm{C},{ }^{*} \\
\mathrm{mr} / \mathrm{hr}\end{array}$ & $\begin{array}{c}\gamma \\
\mathrm{sIC}-3 \mathrm{~B} \\
\mathrm{mr} / \mathrm{hr}\end{array}$ & $\begin{array}{c}\gamma \\
\mathrm{mr} / \mathrm{hr}\end{array}$ & $\begin{array}{c}\Phi, \\
\mathrm{n} / \mathrm{cm}^{2}-\mathrm{sec}\end{array}$ & $\begin{array}{c}\text { Tissue dose } \\
\text { Calc. }\end{array}$ & $\begin{array}{c}\text { rate, mrep/hr } \\
\text { Obs. }{ }^{\dagger}\end{array}$ & $\begin{array}{c}\text { Fraction } \\
\text { of MPE }\end{array}$ \\
\hline 1 & $\begin{array}{l}\text { Control room, foot of } \\
\text { stairs }\end{array}$ & & & 0.02 & 0 & 0.014 & 0 & \\
\hline 2 & $\begin{array}{l}\text { Control room near door } \\
\text { to electron gun room }\end{array}$ & & & 5.09 & 0 & 5.09 & 5.11 (I) & 0.68 \\
\hline 3 & Control room & & & 9.88 & 0 & 9.89 & $12.86(\mathrm{I})$ & 1.71 \\
\hline 4 & $\begin{array}{l}\text { Control room, doorway } \\
\text { to target }\end{array}$ & $11(\mathrm{ow}+\mathrm{sh})$ & 17 & 13.47 & 0 & 13.49 & $14.77(\mathrm{I})$ & 1.97 \\
\hline 5 & Control room near console & & & 3.40 & 0 & 3.40 & 3.26 & 0.43 \\
\hline \multirow[t]{3}{*}{6} & Bottom steps to target & $\begin{array}{l}80(\mathrm{sh}) \\
110(\mathrm{ow})\end{array}$ & $8 \times 20$ & & & & & \\
\hline & Opposite end shield & $\begin{array}{l}200(\mathrm{ow}) \\
100(\mathrm{sh})\end{array}$ & & & & & & \\
\hline & $\begin{array}{l}\text { Corridor, max. near } \\
\text { second fire extinguisher }\end{array}$ & $\sim 5$ & $\sim 3$ & & & & & \\
\hline \multirow[t]{2}{*}{ Room 12} & Drawing table near & $\sim 2$ & $\sim 1.5$ & & & & & \\
\hline & window & 4.5 & 8.5 & & & & & \\
\hline Room 106 & $\begin{array}{l}\text { Above accelerator } \\
\text { left of doorway }\end{array}$ & 10 & 13 & & & & & \\
\hline Room 105 & Lecture hall & 2 & 2 & & & & & \\
\hline 7 & Head of stairs & & & 3.72 & 0 & 3.71 & 3.29 (I) & 0.44 \\
\hline 8 & Door to stock room & & & 8.52 & 0 & 8.51 & 10.26 (I) & 1.37 \\
\hline 9 & Stock room & & & 3.15 & 0 & 3.15 & $3.82(\mathrm{I})$ & 0.51 \\
\hline 10 & Doorway to hall & & & 0.27 & 0.02 & 0.27 & $0.28(I)$ & 0.04 \\
\hline \multirow[t]{2}{*}{11} & $\begin{array}{l}\text { Second fire extinguisher } \\
\text { in hall }\end{array}$ & & & 2.57 & 0 & 2.57 & $2.80(\mathrm{I})$ & 0.37 \\
\hline & $\begin{array}{l}\text { Front of memorial } \\
\quad \text { room, library area }\end{array}$ & 3 & 5 & & & & & \\
\hline
\end{tabular}

* ow, open window, sh, shield, gamma rays only are measured.

$\dagger \mathrm{I}$, integrator. 
Table 27 -SUMMARY OF RADIATION LEVELS AT UNIVERSITY OF ILLINOIS CYCLOTRON (OCTOBER 1955) (Operating Condition: 10-Mev External Deuteron Beam on Carbon Target;

External Beam $=0.8 \mu \mathrm{a}$; Internal Beam $=20 \mu \mathrm{a}$ )

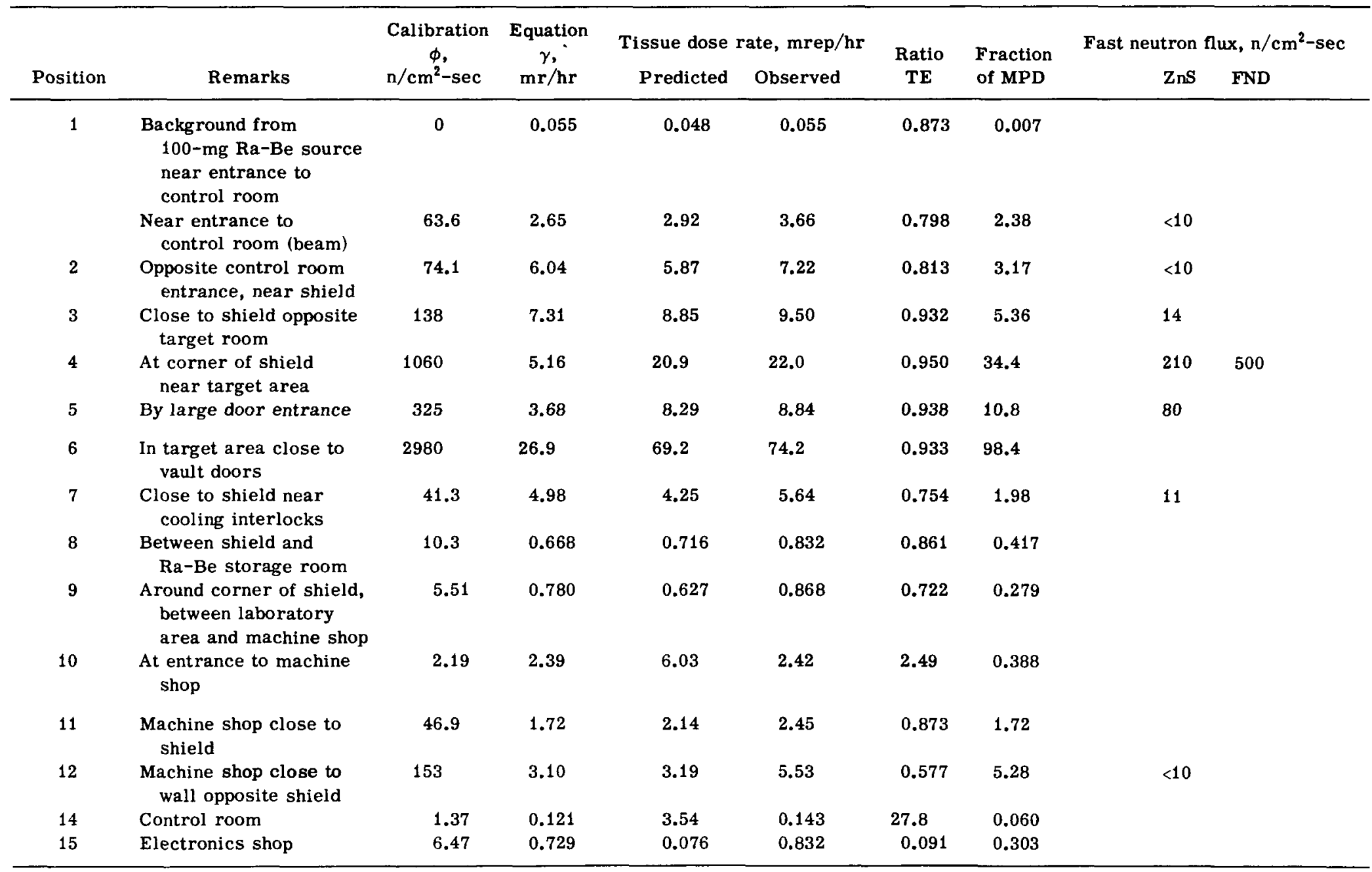


Table 28-SUMMARY OF RADIATION LEVELS AT UNIVERSITY OF ILLINOIS CYCLOTRON (OCTOBER 1955) (Operating Condition: $10-\mathrm{Mev}$ Internal $\mathrm{H}^{2}$ Beam at $20 \mu \mathrm{a}$ )

\begin{tabular}{|c|c|c|c|c|c|c|c|c|}
\hline Position & Remarks & $\begin{array}{c}\text { Calibration } \\
\phi, \\
\mathrm{n} / \mathrm{cm}^{2}-\mathrm{sec}\end{array}$ & $\begin{array}{c}\text { Equation } \\
\gamma \\
\mathrm{mr} / \mathrm{hr}\end{array}$ & $\begin{array}{r}\text { Tissue dose } \\
\text { Predicted }\end{array}$ & $\begin{array}{l}\text { rate, } \mathrm{mrep} / \mathrm{hr} \\
\text { Observed }\end{array}$ & $\begin{array}{l}\text { Ratio } \\
\text { TE }\end{array}$ & $\begin{array}{l}\text { Fraction } \\
\text { of MPD }\end{array}$ & $\begin{array}{c}\text { Fast neutron flux } \\
\text { Zns, } \\
\mathrm{n} / \mathrm{cm}^{2}-\mathrm{sec}\end{array}$ \\
\hline 2 & $\begin{array}{l}\text { Opposite control room } \\
\text { entrance near shield }\end{array}$ & 4.82 & 5.48 & 5.93 & 5.56 & 1.07 & 0.884 & $<10$ \\
\hline 3 & $\begin{array}{l}\text { Close to shield opposite } \\
\text { target room }\end{array}$ & 2.82 & 6.68 & 7.83 & 6.72 & 1.17 & 0.980 & $<10$ \\
\hline 4 & $\begin{array}{l}\text { At corner of shield } \\
\text { near target area }\end{array}$ & 6.11 & 2.85 & 2.18 & 2.95 & 0.739 & 0.574 & \\
\hline 5 & By large door entrance & 3.25 & 1.68 & 1.68 & 1.73 & 0.971 & 0.327 & N.D. \\
\hline 7 & $\begin{array}{l}\text { Close to shield near } \\
\text { cooling interlock }\end{array}$ & 2.62 & 4.56 & 4.52 & 4.60 & 0.983 & 0.691 & N.D. \\
\hline 8 & $\begin{array}{l}\text { Between shield and } \\
\text { Ra-Be storage room }\end{array}$ & 12.0 & 0.427 & 5.37 & 0.618 & 8.69 & 0.439 & \\
\hline 9 & $\begin{array}{l}\text { A round corner of } \\
\text { shield, between labo- } \\
\text { ratory area and } \\
\text { machine shop }\end{array}$ & 7.63 & 0.746 & 0.848 & 0.867 & 0.978 & 0.342 & \\
\hline 10 & $\begin{array}{l}\text { At entrance to machine } \\
\text { shop }\end{array}$ & 9.14 & 0.218 & 0.196 & 0.363 & 0.540 & 0.320 & \\
\hline 11 & $\begin{array}{l}\text { Machine shop close to } \\
\text { shield }\end{array}$ & 4.95 & 2.84 & 3.03 & 2.92 & 1.04 & 0.536 & \\
\hline 12 & $\begin{array}{l}\text { Machine shop close to } \\
\text { wall opposite shield }\end{array}$ & 12.6 & 5.13 & 4.89 & 5.33 & 0.917 & 1.08 & $<10$ \\
\hline 13 & $\begin{array}{l}\text { Close to target area } \\
\text { boundary of machine } \\
\text { shop }\end{array}$ & & & & & & & $<10$ \\
\hline & Near crack in shield & & & & & & & 125 \\
\hline 14 & Control room & 1.40 & 0.420 & 0.378 & 0.442 & 0.855 & 0.101 & N.D. \\
\hline 15 & Electronics shop & 0.083 & 0.131 & 0.076 & 0.132 & 0.576 & 0.020 & N.D. \\
\hline
\end{tabular}




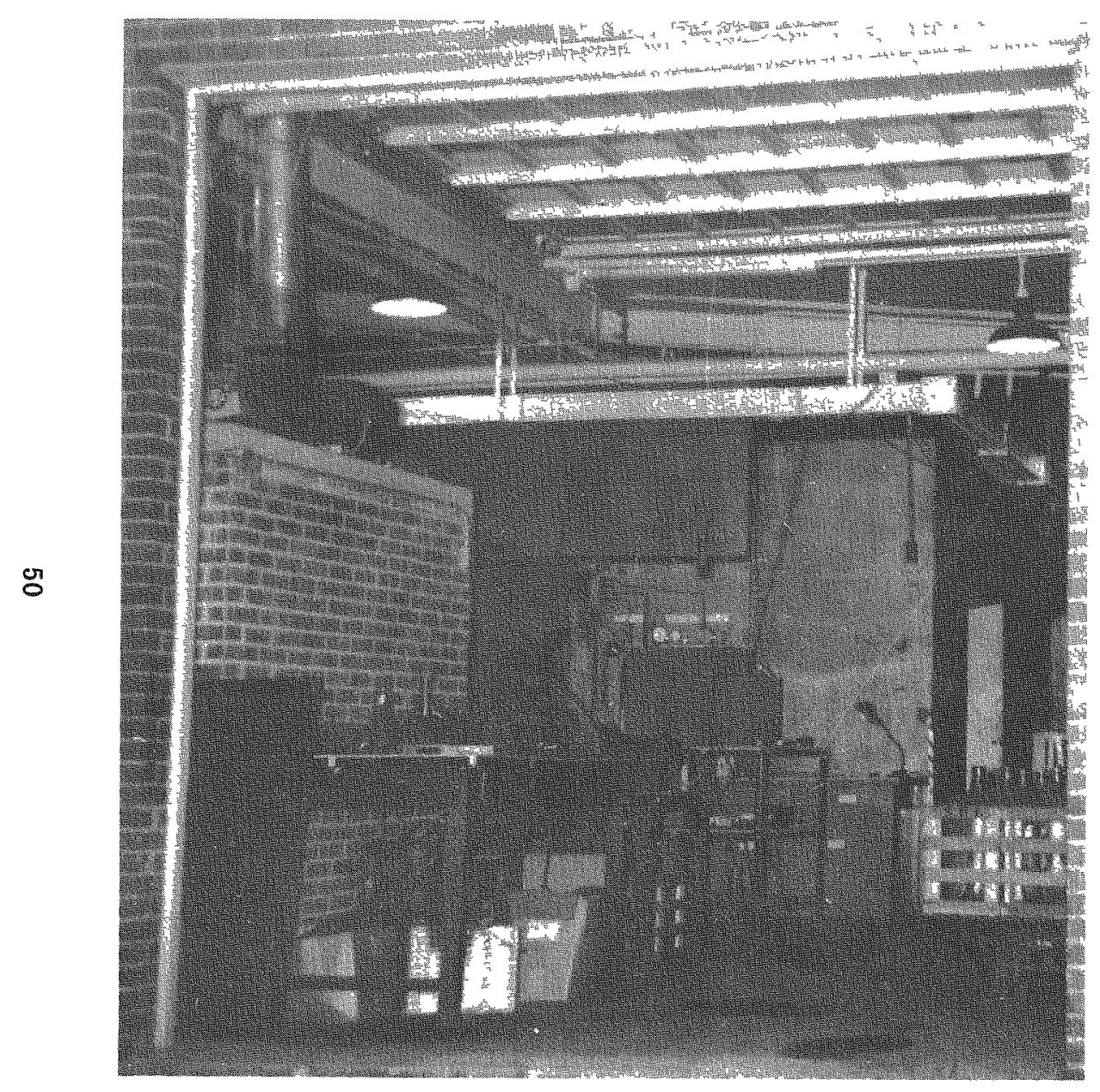

Fig. 23-University of Illinois cyclotron (large door near location 5).

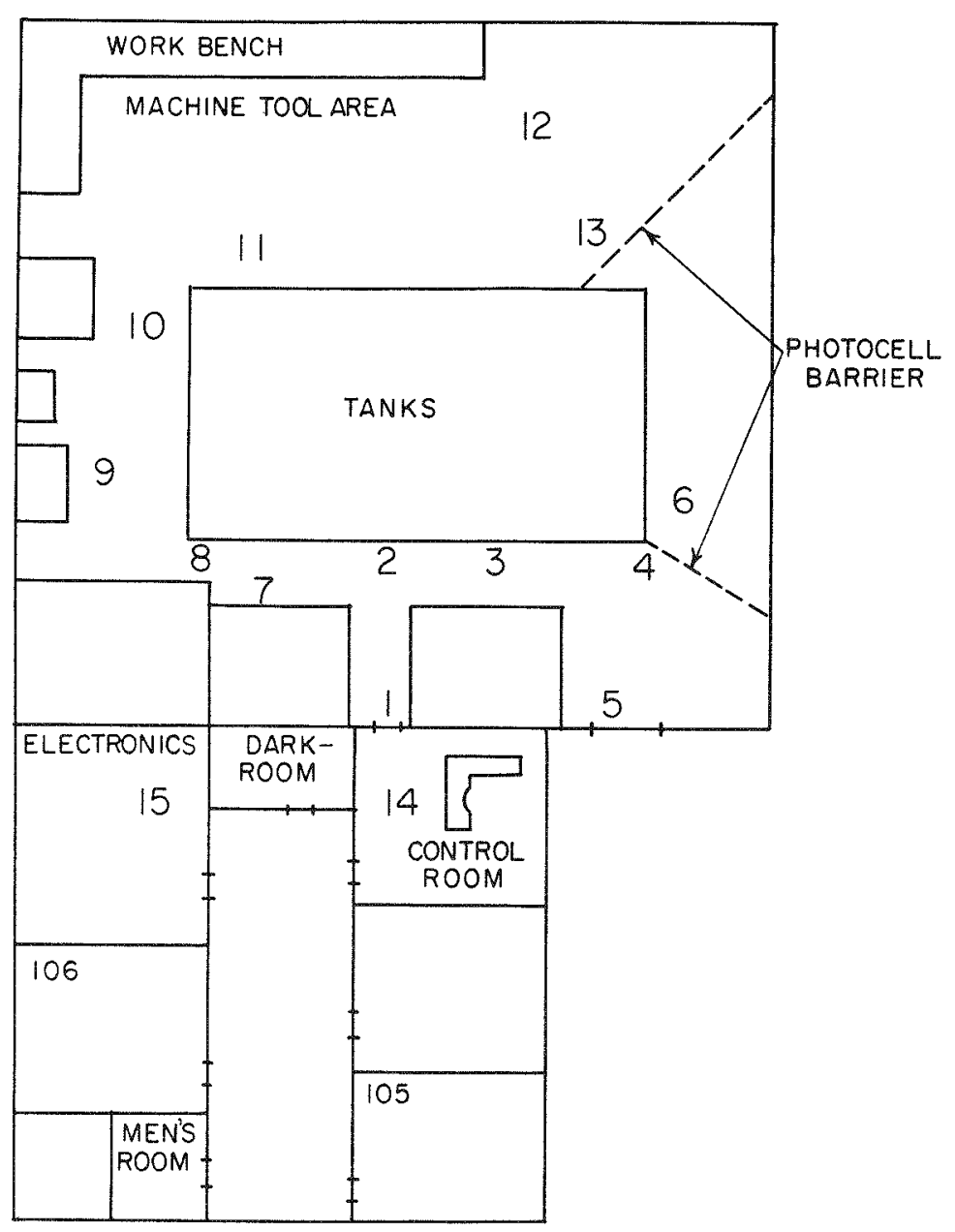

Fig. 24-University of Illinois cyclotron layout. 
Measurements in the control room (location 14) and the electronics shop (location 15) were only about 0.06 and 0.3 times the MPD rate, respectively.

Measurements with the $\mathrm{ZnS}$ scintillation counter on the footpath on the far side of Boneyard Creek indicated less than 10 fast $\mathrm{n} / \mathrm{cm}^{2}-\mathrm{sec}$. Zinc sulfide measurements outside the large door entrance indicated the flux to be 65 fast $\mathrm{n} / \mathrm{cm}^{2}-\mathrm{sec}$.

The radiation level a few inches from the beam port inside the vault, as indicated with a portable ionization chamber (SIC-17C), increased from 150 to $500 \mathrm{mr} / \mathrm{hr}$ during a run of about $6 \mathrm{hr}$.

During internal deuteron beam operation, $x$-ray dose rates and neutron fluxes combined to produce a radiation level about 10 per cent higher than the maximum permissible at one position in the machine shop (location 12). Also, near this position the $\mathrm{ZnS}$ scintillation counter measured a flux of 125 fast $\mathrm{n} / \mathrm{cm}^{2}$-sec through a crack in the shielding. No other radiation levels in excess of the maximum permissible were encountered under this beam condition. The evidence favors the hypothesis that the energy spectrum of the stray neutron radiation is degraded with respect to neutrons emitted from Po-Be. Obviously some care should be used in the interpretation of stray neutron radiation measured with a $\mathrm{ZnS}$ scintillation counter at this site.

On a routine basis the NTA neutron film does not detect neutrons with energies less than $0.5 \mathrm{Mev}$. For this reason the track count alone should not be taken as an estimate of the personnel exposure. Film data should also be examined for higher densities under the cadmium shield than on the open window section of the film.

The following recommendations were made:

1. Since the energy spectrum of the stray neutron radiation from the cyclotron appears to be of a nature largely undetectable by a ZnS scintillation counter of the type used routinely at this site, it was recommended that a Hanson-McKibben $\mathrm{BF}_{3}$ long counter be obtained or built to supplement the scintillation counter measurements.

2. Since high radiation levels occur in the area during external deuteron beam operation, it was recommended that the area be unoccupied during such operation. If this area is needed for laboratory use, the possibility of increased shielding should be considered. In this case it was recommended that the shielding be designed to reduce the possibility of radiation to such levels that no person receives more than 25 per cent of the weekly MPD. The additional safety factor is introduced to allow for the possibility of an augmented beam current in the future.

(b) Large Betatron. The large Illinois betatron produced about 280-Mev electrons; the beam was pulsed about 6 times/sec. An integrating ionization chamber beam monitor read about $0.4 \mathrm{ma} / \mathrm{min}(1-\mu \mathrm{f}$ condenser) with a $1 / 4$-in. collimator. The dose rate in the beam was estimated to be about 2800 to $3000 \mathrm{r} / \mathrm{min} 1$ meter from the $\mathrm{x}$-ray target, although, of course, the roentgen does not strictly apply for very high energy $x$ rays.

Measurements were made at the selected locations shown in Fig. 25 with the three ionization chambers previously described and an ionization chamber survey meter, SIC-17C.

Table 29 summarizes the stray radiation levels encountered. The column " $\gamma$ (Juno)" lists simply the $\mathrm{x}$-ray dose rates obtained with an SIC-17C calibrated with $\mathrm{Co}^{60}$ gamma rays. Estimates of $\gamma$ and $\phi$ were inferred from the $\mathrm{BF}_{3}$ and $\mathrm{CO}_{2}$ chamber measurements and the calibration equations. The calculated TE dose rate depends on the TE chamber equation and the values $\gamma$ and $\phi$; the observed TE dose rate is simply the TE chamber reading converted to $\mathrm{mrep} / \mathrm{hr}$ on the basis of a radium gamma-ray calibration.

For a mixed field of radium gammas and Po-Be neutrons, the ratio of observed TE dose rate to the calculated would be unity. Departures from unity result from measurements made of gammas and/or neutrons that have different energies from radium and $\mathrm{Po-Be}$ neutrons. Departures can also be attributed to preferential scattering into one of the ionization chambers by local shields or persons in the vicinity, and possibly by the existence of steep gradients of radiation levels since the chambers are usually about $1 \mathrm{ft}$ apart. The last reason for departure of the ratio from unity was easily checked by a survey meter.

Radiation levels were uniformly low in all the occupied locations examined except location 2. Locations 1,8 , and 9 are inside the accelerator proper area and can be occupied only by crossing an interlocked photocell or doorway but may be of interest to the 300-Mev betatron group. The $x$-ray level in location 2, near the photoelectric cell interlock, was about 3.5 times the MPD rate. Estimates of neutron fluxes, presumably due to photoneutron reactions, were 


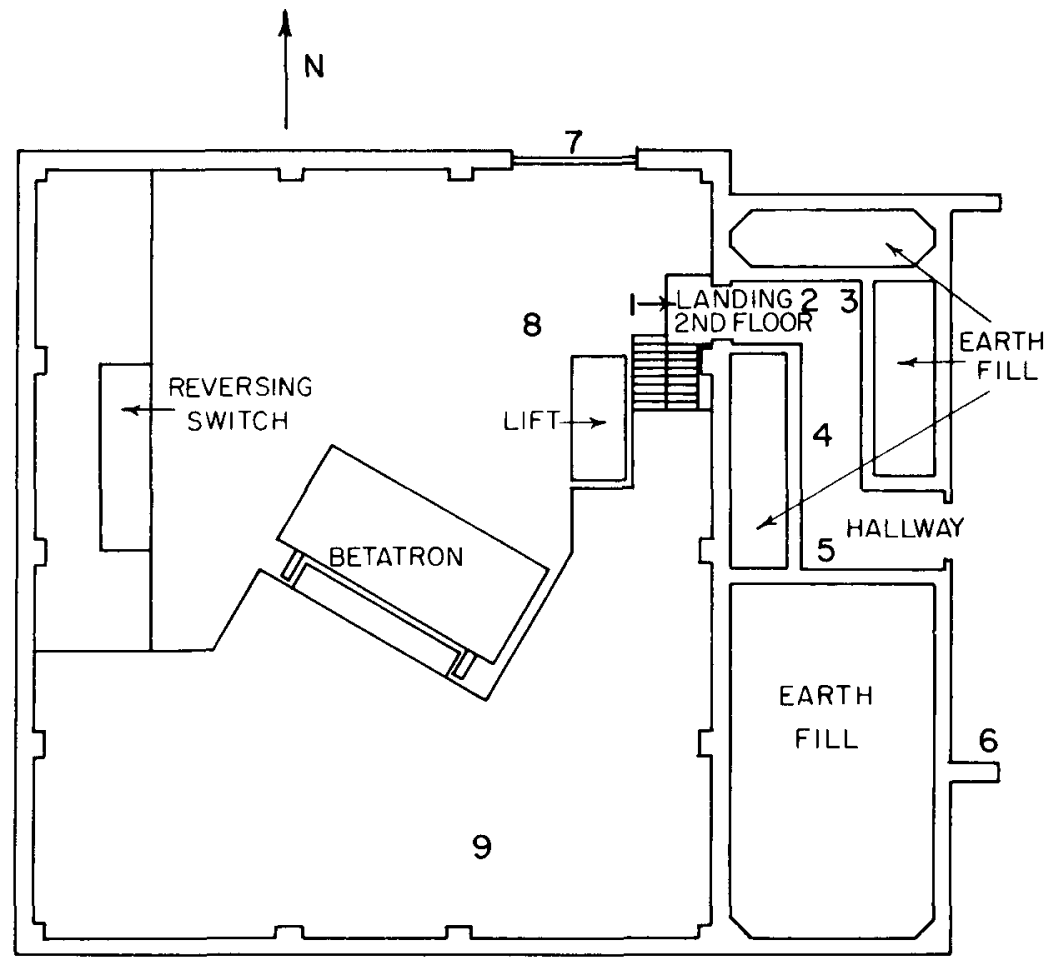

Fig. 25-University of Illinois 300-Mev betatron layout.

hardly significant except inside the betatron vault. These estimates of $\phi$ are the equivalent Po-Be neutron fluxes, the maximum permissible being about $30 \mathrm{n} / \mathrm{cm}^{2}-\mathrm{sec}$ for $40 \mathrm{hr}$.

Measurements were made at location 7 to determine whether or not the neutron flux estimates really represent neutrons. The results in Table 30 indicate the presence of thermal neutrons because a cadmium shield around the $\mathrm{BF}_{3}$ ionization chamber reduced the reading markedly. Furthermore, the addition of a $2 \frac{1}{4}$-in. polyethylene absorber (optimum thickness for Po-Be neutrons) to the bare $\mathrm{BF}_{3}$ chamber elevated the reading, presumably by thermalizing fast neutrons. Since the first comparison (cadmium difference) indicates the existence of thermal neutrons and the second (polyethylene build-up) implies the existence of higher energy neutrons, the authors are inclined to accept the $\phi$ estimates as reasonable, at least in the sense that photoneutrons are actually being produced in detectable amounts.

It is unlikely that low-energy $x$ rays would cause the difference in reading accompanied by the addition of cadmium since the $\mathrm{BF}_{3}$ chamber was surrounded by $2.25 \mathrm{in}$. of polyethylene.

The last column in Table 29 (Fraction of MPD) lists the ratio of the observed TE dose rate to $7.5 \mathrm{mr} / \mathrm{hr}$ in occupied places, where neutron fluxes are negligible in terms of the maximum permissible level compared to the $x$-ray levels.

No radiation levels were detected outside the south side of the laboratory.

The radiation levels in all potentially occupied areas were always less than the maximum permissible level except in locations 2 and 7.

Location 2, which is near the photoelectric interlock leading to the vault stairs, was subject to levels about 3.5 times the MPD rate, $7.5 \mathrm{mr} / \mathrm{hr}$. No neutrons were detected in this place. It is suggested therefore that this area never be occupied more than $11 \mathrm{hr}$ in any week by any one person for the type of betatron operation used during the survey. The level at location 2 must be reevaluated if higher beam currents or energies are used. However, the reported levels may be scaled down for lower beam currents, although a reevaluation would still be advisable.

The advisability of placing a placard on the door at location 7 should be investigated. Although the levels here are only about one-half the MPD rate, it seems inadvisable to expose public areas to significant radiation levels. Either an appropriate radiation warning sign placed 
Table 29-SUMMARY OF RADIATION LEVELS AT UNIVERSITY OF ILLINOIS 300-MEV BETATRON (OCT. 7, 1955) [Operating Condition: $280-\mathrm{Mev}$ Electrons; Monitor $0.4 \mathrm{ma} / \mathrm{min}(1-\mu \mathrm{f}$ Condenser); Beam $\cong 2800$ to $3000 \mathrm{r} / \mathrm{min}$ at $100 \mathrm{~cm}$ ]

\begin{tabular}{|c|c|c|c|c|c|c|c|c|}
\hline \multirow[b]{3}{*}{ Location } & \multirow[b]{3}{*}{ Description } & \multirow{3}{*}{$\begin{array}{c}\gamma \\
\text { Juno, } \\
\mathrm{mr} / \mathrm{hr}\end{array}$} & \multicolumn{2}{|c|}{ Calibration equation } & \multirow{2}{*}{\multicolumn{2}{|c|}{ Tissue dose rate, mrep $/ \mathrm{hr}$}} & \multirow{3}{*}{$\begin{array}{c}\text { Ratio } \\
\text { TE } \\
\text { (obs./calc.) }\end{array}$} & \multirow{3}{*}{$\begin{array}{l}\text { Fraction } \\
\text { of MPD }\end{array}$} \\
\hline & & & \multirow{2}{*}{$\begin{array}{c}\gamma \\
\mathrm{mr} / \mathrm{hr}\end{array}$} & \multirow{2}{*}{$\begin{array}{c}\phi, \\
\mathrm{n} / \mathrm{cm}^{2}-\mathrm{sec}\end{array}$} & & & & \\
\hline & & & & & Calc. & Obs. & & \\
\hline 1 & Head of stairs & 30 & 17.9 & 18.6 & 18.2 & & & \\
\hline 2 & $\begin{array}{l}\text { End of corridor } \\
\text { right of aisle } \\
\text { (higher beam) }\end{array}$ & 23 & 25.2 & 0 & 25.3 & 26.2 & 1.04 & 3.49 \\
\hline 3 & & $\sim 1$ & 0.59 & 0.89 & 0.60 & 0.71 & 1.18 & 0.09 \\
\hline 4 & $\begin{array}{l}\text { Opposite lockers } \\
4 \text { and } 5\end{array}$ & N.D. & N.D. & N.D. & N.D. & N.D. & & \\
\hline 5 & $\begin{array}{l}\text { Entrance to } \\
\text { control room }\end{array}$ & N.D. & N.D. & N.D. & N.D. & N.D. & & \\
\hline 6 & Drafting room & N.D. & 0.02 & N.D. & 0.02 & N.D. & & \\
\hline 7 & Outside door & $\sim 2$ & 2.65 & 2.15 & 2.68 & 3.58 & 1.34 & 0.48 \\
\hline 8 & $\begin{array}{l}\text { Inside door } \\
\quad \text { (excluded area) }\end{array}$ & & 6.63 & 12.54 & 6.45 & 11.93 & 1.75 & \\
\hline 9 & Excluded area & & $1.46^{*}$ & N.D. & & 3.34 & & \\
\hline
\end{tabular}

* Estimated from $\mathrm{CO}_{2}$ chamber reading. 


\begin{tabular}{ll}
\hline \multicolumn{1}{c}{ Description } & $\begin{array}{c}\text { V.R.E. reading } \\
\left(10^{10} \mathrm{ohms}\right),{ }^{*} \mathrm{mv}\end{array}$ \\
\hline $\mathrm{BF}_{3}($ bare $)$ & $\sim 10$ \\
$\mathrm{BF}_{3}($ bare $+\mathrm{Cd})$ & $\sim 5$ \\
$\mathrm{BF}_{3}(2.25-$ in. polyethylene $)$ & $15-20$ \\
$\mathrm{BF}_{3}($ polyethylene $+\mathrm{Cd})$ & $10-15$ \\
\hline
\end{tabular}

* Measurements were made with a $10^{10}-\mathrm{ohm}$ resistor across the electrometer capacitor; the instrumental variation is noted.

on the door or a periodic spot check by the betatron operator may prove to be adequate control for location 7 .

(c) 22-Mev Betatron. The 22-Mev llinois betatron produced about 19.5-Mev electrons on the date of the survey. The dose rate $100 \mathrm{~cm}$ from the molybdenum target was about $60 \mathrm{r} / \mathrm{min}$. The betatron was pulsed about 180 times/sec with a pulse duration of 1 usec. Radiation measurements were made at the locations appearing in Fig. 26.

Stray radiation levels near the 22-Mev betatron observed on the date of the survey are shown in Table 31. The levels were uniformly low except in the control room, locations $A$ through D. A slight "hot" spot was encountered at location $H$ (4 to $5 \mathrm{mr} / \mathrm{hr}$ ), presumably due to the thinner shielding between this place and the betatron proper. Significant neutron levels seemed to be present according to the $\mathrm{BF}_{3}-\mathrm{CO}_{2}$ measurements, although no substantiating measurements were made. In locations $\mathrm{D}$ and $\mathrm{E}$ these fluxes are much less important in terms of the maximum permissible level than the corresponding $x$-ray dose rate.

The last column in Table 31 lists the fraction of the MPD rate represented by the total (first-collision) dose rate as measured by the TE ionization chamber, except location $B$.

The gradient of radiation levels between locations $A$ and $B$ is considerable. A person must remain $23.5 \mathrm{hr}$ in location $A$ with the betatron on before accumulating a weekly MPD, but at location B the weekly MPD can be obtained in about $20 \mathrm{~min}$.

No significant levels were encountered outside the chain-link fence south of the betatron.

Betatron operations employing higher energies and other targets will, of course, require a reevaluation of the stray radiations.

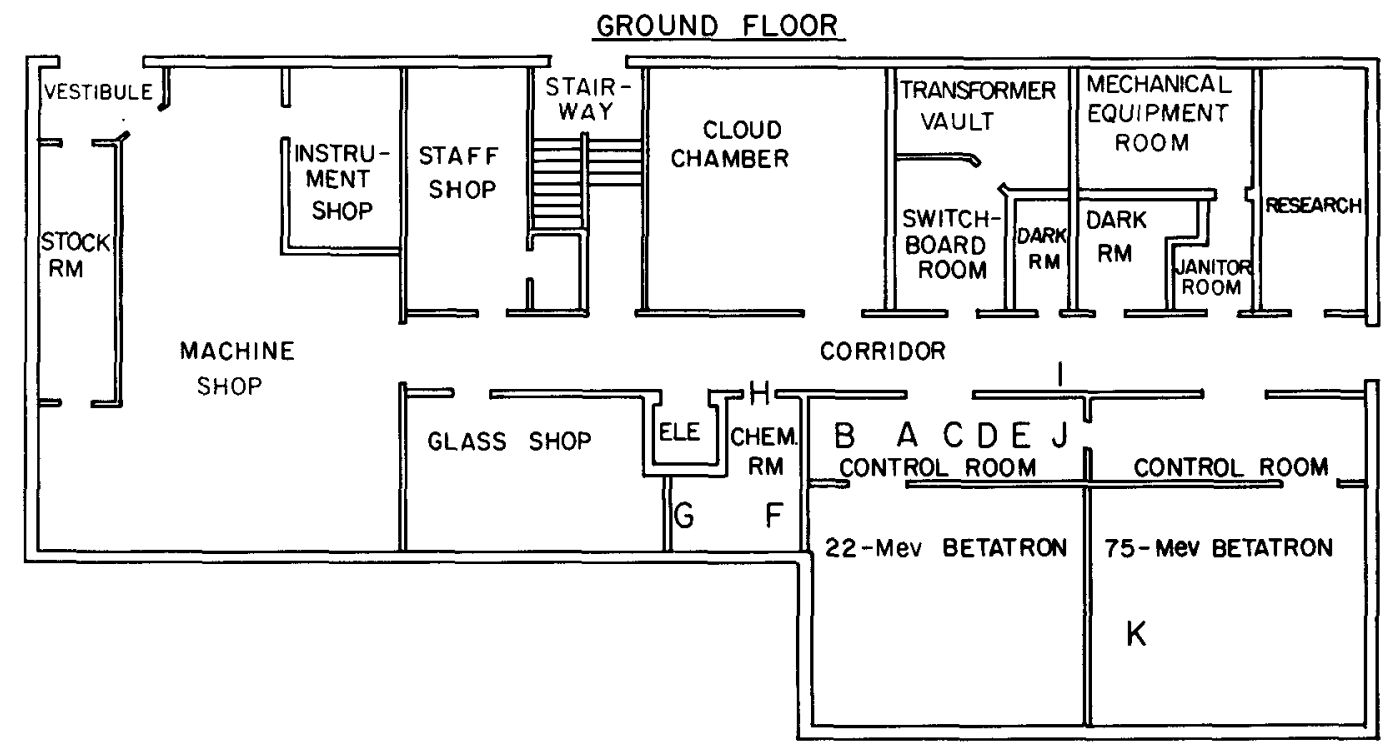

Fig. 26-University of Illinois 22-Mev betatron layout. 
Table 31 -SUMMARY OF RADIATION LEVELS AT UNIVERSITY OF ILLINOIS 22-MEV BETATRON (OCT. 7, 1955)

(Operating Condition: 19.5-Mev Electrons; 180 Pulses/sec, 1- $\mu$ sec Duration;

Dose Rate from Molybdenum Target $\cong 60 \mathrm{r} / \mathrm{min}$ at $100 \mathrm{~cm}$ )

\begin{tabular}{|c|c|c|c|c|c|c|c|c|}
\hline \multirow[b]{2}{*}{ Location } & \multirow[b]{2}{*}{ Description } & \multicolumn{3}{|c|}{ Calibration equation } & \multirow[b]{2}{*}{$\begin{array}{c}\text { Tissue dose } \\
\text { Calc. }\end{array}$} & \multirow[b]{2}{*}{$\begin{array}{l}\text { rate, } \mathrm{mrep} / \mathrm{hr} \\
\text { Obs.* }\end{array}$} & \multirow[b]{2}{*}{$\begin{array}{c}\text { Ratio } \\
\text { TE } \\
\text { (obs./calc.) }\end{array}$} & \multirow[b]{2}{*}{$\begin{array}{l}\text { Fraction } \\
\text { of MPD }\end{array}$} \\
\hline & & $\begin{array}{c}\gamma \\
\text { Juno }\end{array}$ & $\begin{array}{c}\gamma \\
\mathrm{mr} / \mathrm{hr}\end{array}$ & $\begin{array}{c}\phi, \\
\mathrm{n} / \mathrm{cm}^{2}-\mathrm{sec}\end{array}$ & & & & \\
\hline A & Control room & $13 \mathrm{mr} / \mathrm{hr}$ & 11.9 & 9.2 & 12.0 & $10.3(\mathrm{R})$ & 0.86 & 1.60 \\
\hline $\mathbf{B}$ & $\begin{array}{l}\text { Control room, door } \\
\text { to vault }\end{array}$ & $\sim 1 \mathrm{r} / \mathrm{hr}$ & & & & $210(\mathrm{R})$ & & 133 (Juno) \\
\hline \multicolumn{9}{|c|}{ 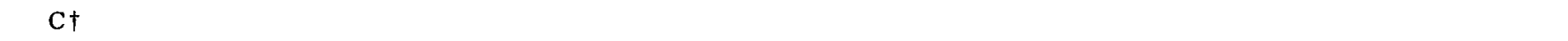 } \\
\hline $\mathrm{D}$ & Control room & $\sim 6 \mathrm{mr} / \mathrm{hr}$ & 4.7 & 15.4 & 4.92 & 5.25 & 1.07 & 0.70 \\
\hline $\mathbf{E}$ & $\begin{array}{l}\text { Control room, } \\
\text { near console }\end{array}$ & $\sim 2.5 \mathrm{mr} / \mathrm{hr}$ & 2.9 & 4.0 & 2.54 & 1.49 & 0.59 & 0.20 \\
\hline $\mathrm{F}$ & Chemistry room & N.D. & 1.0 & 1.5 & 1.02 & 1.27 & 1.25 & 0.17 \\
\hline G & Chemistry room $\ddagger$ & N.D. & & & & & 0.78 & 0.10 \\
\hline $\mathrm{H}$ & $\begin{array}{l}\text { Entrance to } \\
\text { chemistry room } \ddagger\end{array}$ & $\sim 5 \mathrm{mr} / \mathrm{hr}$ & 3.7 & 0 & & & 2.70 & 0.36 \\
\hline I & Corridor & $\sim 1 \mathrm{mr} / \mathrm{hr}$ & 0.16 & 0 & & & 0.13 & 0.02 \\
\hline $\mathrm{J}$ & Control room $\ddagger$ & N.D. & 0.66 & 0 & & & 0.66 & 0.09 \\
\hline $\mathrm{K}$ & 70-Mev betatron $\ddagger$ & N.D. & 0.05 & 0 & & & 0.05 & 0.007 \\
\hline
\end{tabular}

* $R$, rate meter.

$\dagger$ No measurements were made at this location.

$\ddagger$ Inferred from $\mathrm{TE}$ and $\mathrm{CO}_{2}$ readings alone. 
Because of the generally low levels measured at the time of the survey, only one recommendation was made. It was suggested that the area immediately in front of the entrance to the vault, location $B$, be roped off and placarded with an appropriate radiation warning sign when the betatron is in operation. However, this radiation warning sign should not be displayed when the accelerator is off.

\subsection{University of Virginia}

The Virginia Van de Graaff accelerator survey was performed in September 1956 during the production of D-T as well as D-D neutrons. The accelerator is located in the basement of the new physics building. Measurements were made at the locations shown in Fig. 27 for both kinds of neutron production. As shown in Fig. 28, the accelerator assembly is positioned horizontally with the deuteron beam emerging to the west (behind the shield in the photograph) into the target area. Beyond the target area, or vault, is an electronics shop. A view of the control area (location 1) appears in Fig. 29.

The Van de Graaff is used to accelerate deuterons to about $2 \mathrm{Mev}$. The beam currents most often utilized under normal operating conditions prior to the survey were 2 to $3 \mu \mathrm{a}$ with a tritium target and $13 \mu \mathrm{a}$ with a deuterium target. Measurements are recorded in Tables 32 to 34 for three target conditions.

1. An external tritium target to produce neutrons with energies up to $\sim 16 \mathrm{Mev}$ (Table 32).

2. Same as above with an aluminum collimator (Table 33).

3. An external deuterium target to produce neutrons with energies up to about $5 \mathrm{Mev}$ (Table 34).

The radiation levels recorded under the tritium target condition are all well below the MPD values, with the exception of those observed in the west room and on the laboratory floor above the vault. With a beam current of $10 \mu \mathrm{a}$, the Nemo registered a fast neutron flux of about double the MPD in the west room. This value may not accurately represent this flux because of the small amount of moderating material in the instrument, which results in a more efficient detection of intermediate and low energies. This is indicated by the lower reading of the Thompson instrument, whose low-energy threshold is about $0.2 \mathrm{Mev}$. Readings made with the Thompson instrument for the various positions and beam conditions are consistent and are probably a more reliable indication of the actual fast neutron flux.

The maximum reading observed in the laboratory on the floor above is approximately the MPD value, and the radiation level was greater than one-third of this value within a radius of

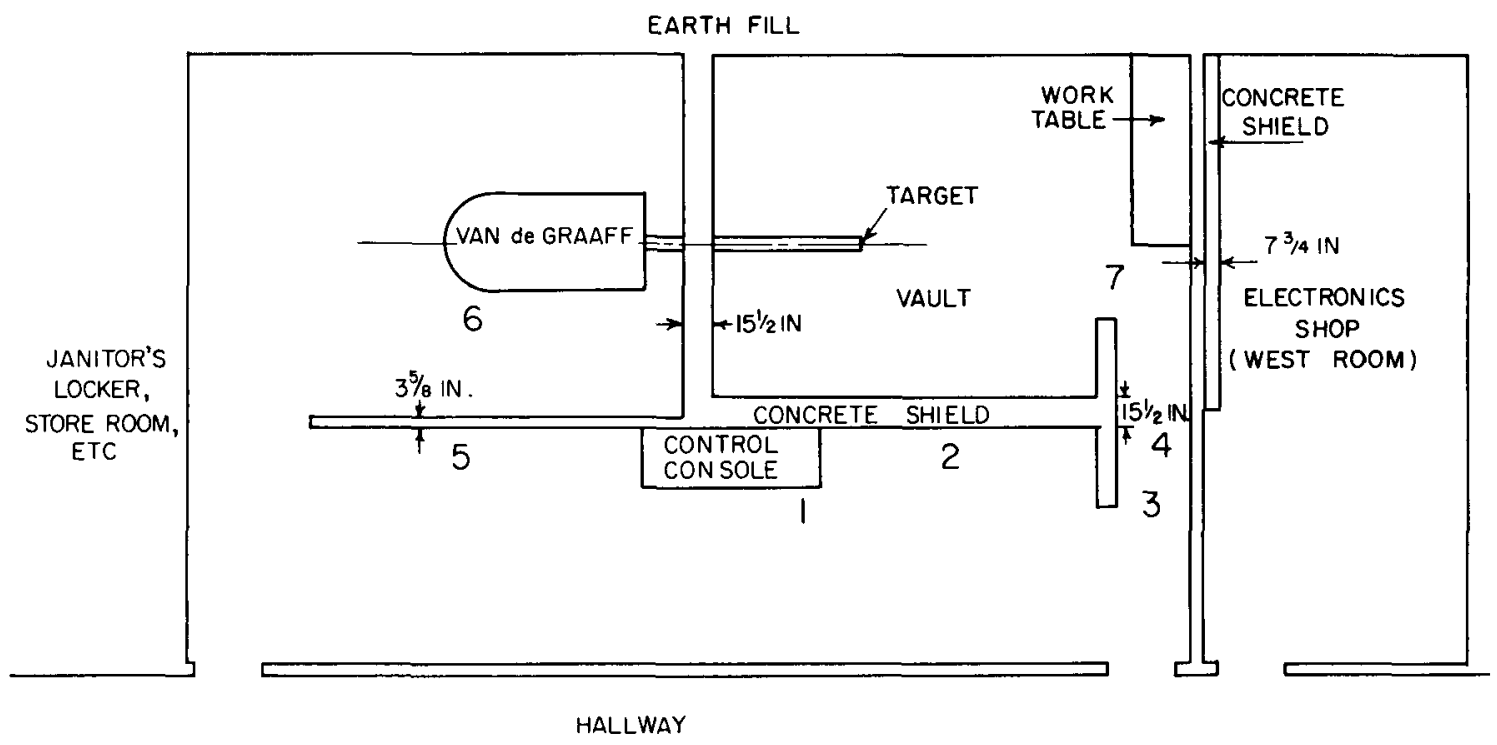

Fig. 27-University of Virginia Van de Graaff layout. 


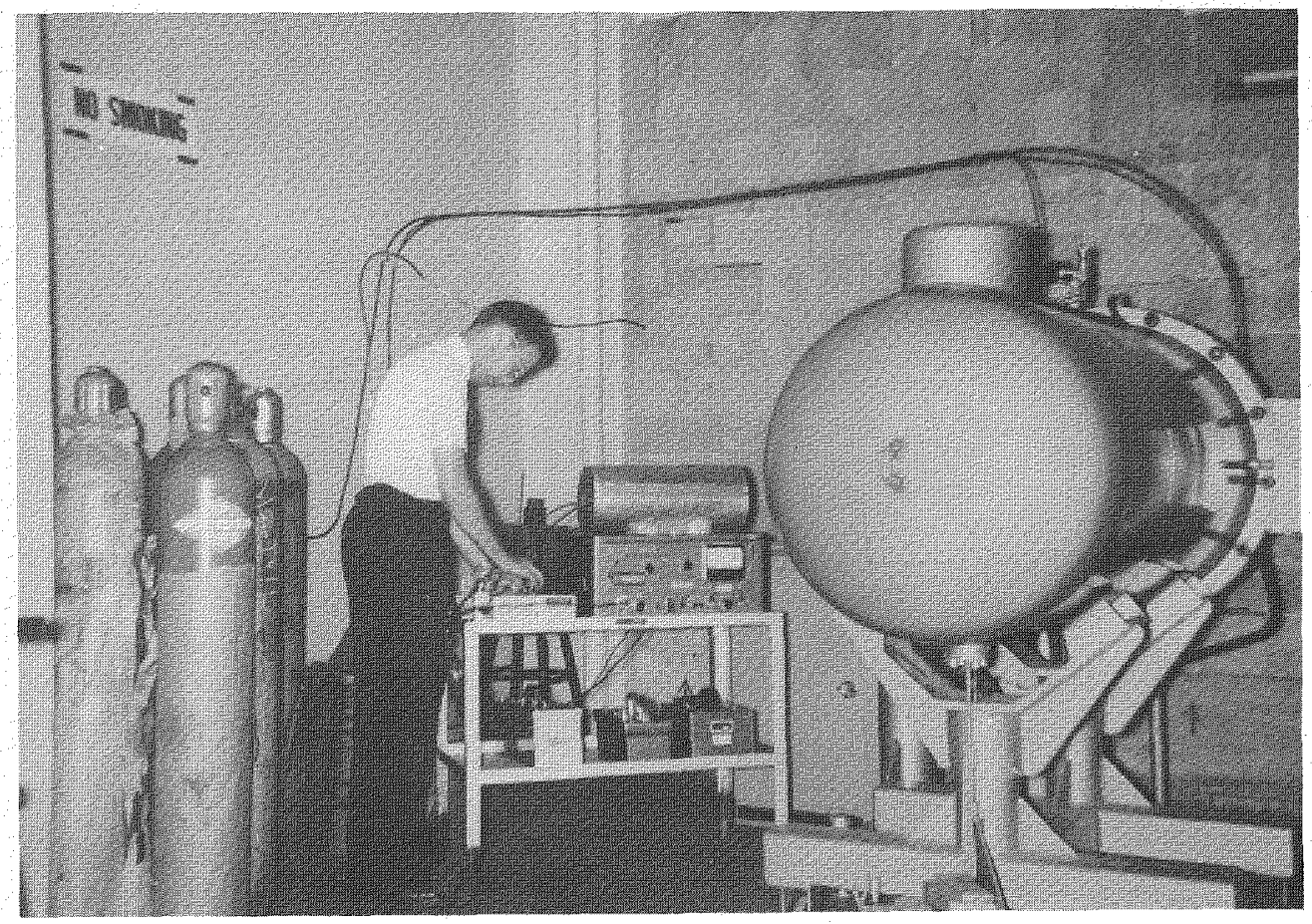

Fig. 28-University of Virginia Van de Graaff assembly.

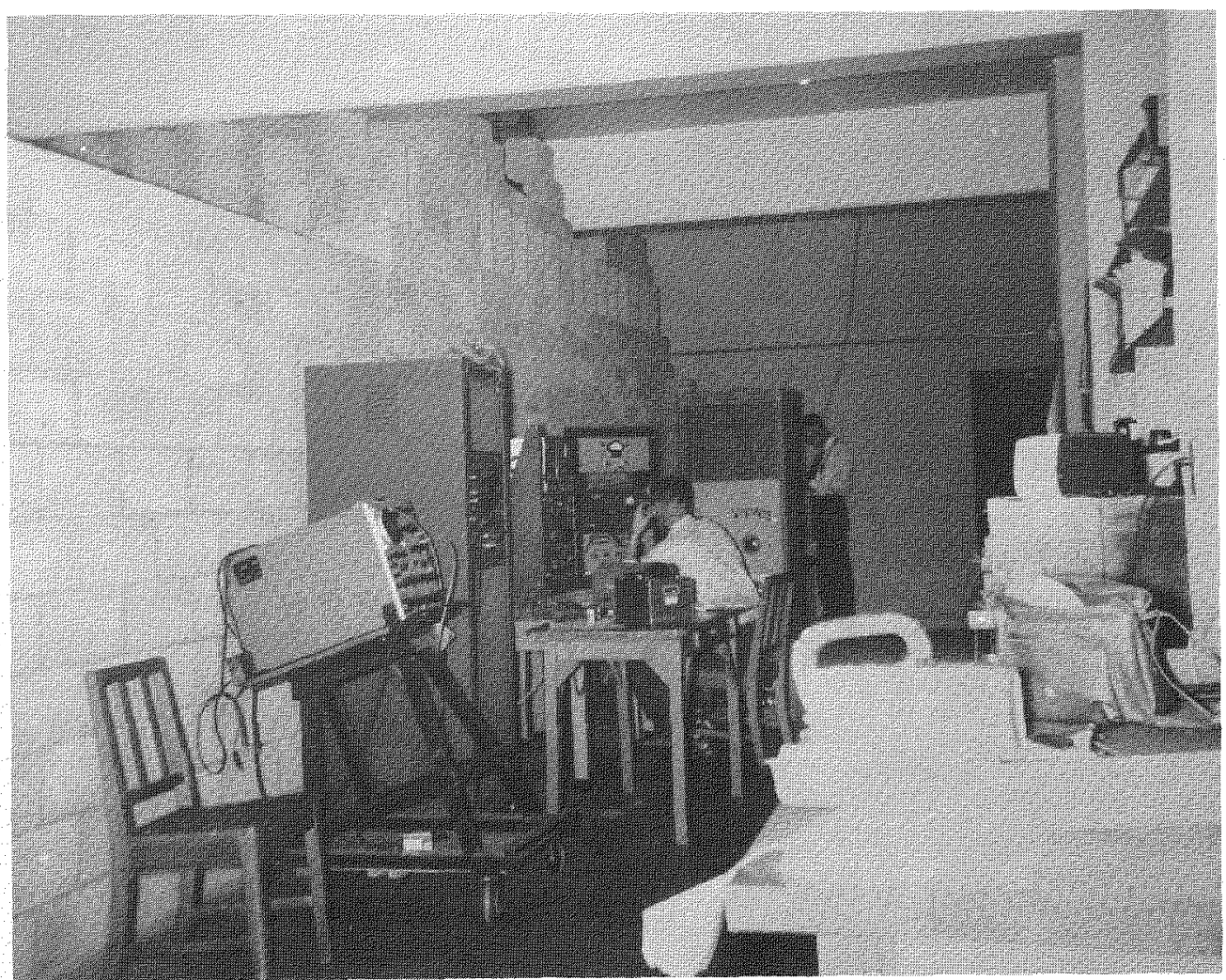

Fig. 29-University of Virginia Van de Graaff, north shield wall and control panel. 
Table 32 - SUMMARY OF RADIATION LEVELS FOR DEUTERON BEAM ON TRITIUM TARGET WITHOUT COLLIMATOR AT UNIVERSITY OF VIRGINIA VAN DE GRAAFF (SEPTEMBER 1956)

\begin{tabular}{|c|c|c|c|c|c|c|c|c|c|}
\hline \multirow[b]{2}{*}{ Location } & \multirow{2}{*}{$\begin{array}{c}\text { Beam current, } \\
\mu \mathrm{a}\end{array}$} & \multirow{2}{*}{$\begin{array}{c}\text { BF } F_{3} \text { L.C., } \\
\mathrm{n}_{\mathrm{f}} / \mathrm{cm}^{2}-\mathrm{sec}\end{array}$} & \multicolumn{2}{|c|}{ Thompson } & \multirow{2}{*}{$\begin{array}{c}\mathrm{ZnS}, \\
\mathrm{n}_{\mathrm{f}} / \mathrm{cm}^{2}-\mathrm{sec}\end{array}$} & \multicolumn{2}{|c|}{$\mathrm{BF}_{3}-\mathrm{CO}_{2}$} & \multicolumn{2}{|c|}{$\mathrm{TE}, \mathrm{mrep} / \mathrm{hr}$} \\
\hline & & & $\overbrace{\mathrm{n}_{\mathrm{f}} / \mathrm{cm}^{2}-\mathrm{sec}}$ & $\mathrm{n}_{\mathrm{t}} / \mathrm{cm}^{2}-\mathrm{sec}$ & & $\overbrace{\mathrm{n} / \mathrm{cm}^{2}-\mathrm{sec}}$ & $\overline{\mathrm{mr} / \mathrm{hr} \gamma}$ & Calc. & Obs. \\
\hline 1 & 2 & 3.38 & & & & 0.241 & 0.046 & 0.050 & 0 \\
\hline 2 & 2 & 3.38 & & & & & & & \\
\hline 4 & 2 & 7.11 & & & & & & & \\
\hline 5 & 2 & & & & & 0.048 & 0.048 & 0.049 & 0 \\
\hline $\begin{array}{l}\text { West room, } \\
\text { wall }\end{array}$ & 3 & & & & 47 & & & & \\
\hline $\begin{array}{l}\text { Laboratory above } \\
\text { accelerator }\end{array}$ & 4.2 & & 81.7 & & 39 & & & & \\
\hline 1 & 4.3 & & & & & 0.901 & 0.074 & 0.088 & 0 \\
\hline $\begin{array}{l}\text { West room, } \\
\text { wall }\end{array}$ & 4.5 & & 4.4 & & 0 & & & & \\
\hline $\begin{array}{l}\text { West room, } \\
\text { far corner }\end{array}$ & 4.5 & & 3.8 & & 0 & & & & \\
\hline 1 & 10 & & 2.7 & 42 & $\sim 0$ & & & & \\
\hline 5 & 10 & & 1.4 & 24 & & & & & \\
\hline $\begin{array}{l}\text { West room, } \\
\text { SE corner }\end{array}$ & 10 & & 10.9 & 96 & & & & & \\
\hline 1 & 11 & & & & & 52.2 & 0 & 0.83 & 0.28 \\
\hline
\end{tabular}


Table 33-SUMMARY OF RADIATION LEVELS FOR DEUTERON BEAM ON TRITIUM TARGET WITH ALUMINUM COLLIMATOR AT UNIVERSITY OF

OF VIRGINIA VAN DE GRAAFF

\begin{tabular}{ccccc}
\hline Location & $\begin{array}{c}\text { Beam current, } \\
\mu \mathrm{a}\end{array}$ & $\begin{array}{c}\mathrm{Juno} \\
\mathrm{mr} / \mathrm{hr}\end{array}$ & $\begin{array}{c}\mathrm{BF} \text { L.C., } \\
\mathrm{n}_{\mathrm{f}} / \mathrm{cm}^{2}-\mathrm{sec}\end{array}$ & $\begin{array}{l}\text { Thompson, } \\
\mathrm{n}_{\mathrm{f}} / \mathrm{cm}^{2}-\mathrm{sec}\end{array}$ \\
\hline 1 & 2 & 0 & 1.14 & 0.82 \\
2 & 2 & 0 & 1.05 & 0.82 \\
3 & 2 & 0 & 1.42 & 0.82 \\
4 & 2 & 0 & 3.43 & 1.09 \\
5 & 2 & 0 & 2.34 & 0.82 \\
6 & 2 & 0 & 2.23 & 0.55 \\
\hline
\end{tabular}

Table 34-SUMMARY OF RADIATION LEVELS FOR DEUTERON BEAM ON DEUTERIUM TARGET AT UNIVERSITY OF VIRGINIA VAN DE GRAAFF

\begin{tabular}{|c|c|c|c|c|c|c|c|c|}
\hline \multirow[b]{2}{*}{ Location } & \multirow{2}{*}{$\begin{array}{c}\text { Beam current, } \\
\mu \mathrm{a}\end{array}$} & \multirow{2}{*}{$\begin{array}{c}\gamma \\
\text { Juno, } \\
\mathrm{mr} / \mathrm{hr}\end{array}$} & \multirow{2}{*}{$\begin{array}{c}\text { BF } F_{3} \text { L.C., } \\
\mathrm{n}_{\mathrm{f}} / \mathrm{cm}^{2}-\mathrm{sec}\end{array}$} & \multicolumn{2}{|c|}{ Thompson } & \multicolumn{2}{|c|}{ Nemo } & \multirow{2}{*}{$\begin{array}{c}\mathrm{ZnS} \\
\mathrm{n} / \mathrm{cm}^{2}-\mathrm{sec}\end{array}$} \\
\hline & & & & $\mathrm{n}_{\mathrm{f}} / \mathrm{cm}^{2}-\mathrm{sec}$ & $\mathrm{n}_{\mathrm{t}} / \mathrm{cm}^{2}-\mathrm{sec}$ & $\mathrm{n}_{\mathrm{f}} / \mathrm{cm}^{2}-\mathrm{sec}$ & $\mathrm{n}_{\mathrm{t}} / \mathrm{cm}^{2}-\mathrm{sec}$ & \\
\hline 1 & 13 & 0.5 & 4.7 & 0.55 & 60 & 20 & 40 & \\
\hline 2 & 13 & & 5.4 & 1.6 & 78 & 20 & 30 & \\
\hline 4 & 13 & & 25.5 & 4.9 & 216 & 100 & 100 & \\
\hline 5 & 13 & 4 & & 0.55 & 18 & 10 & 15 & \\
\hline 6 & 13 & & 4.7 & 5.45 & 42 & 200 & 150 & \\
\hline West room & 13 & & & & & & & 35 \\
\hline $\begin{array}{l}\text { Bottom of } \operatorname{tank} \\
\text { at rack }\end{array}$ & 13 & 500 & & & & & & \\
\hline $\begin{array}{r}\text { Bottom of tank } \\
\text { halfway back }\end{array}$ & 13 & 1000 & & & & & & \\
\hline 7 & 50 & & & & & & 500 & \\
\hline
\end{tabular}


$8 \mathrm{ft}$ from the point of the maximum, located at about the center of the large room. No measurable fluxes were observed near the desks at the east end of the room.

The readings obtained during the bombardment of a deuterium target were all of little consequence, except for the Nemo fast neutron flux values at positions 4 and 6 . The high thermal neutron flux readings at these points indicate that the mechanism described above may be at fault. As expected, high gamma readings were recorded at the surface of the tank, but little radiation was recorded next to the shielding wall.

Estimates of the neutron yield were $3 \times 10^{7} \mathrm{n} / \mathrm{sec}-\mu$ a plus $0.53 \mathrm{mrhm} / \mu \mathrm{a}$ for $\mathrm{D}-\mathrm{T}$ neutrons and $1.44 \times 10^{7} \mathrm{n} / \mathrm{sec}-\mu$ a plus an insignificant amount of $x$ rays for the $D-D$ case.

1. It was recommended that all personnel involved in the routine operation of the Van de Graaff routinely use a neutron-gamma film badge.

2. Because neutron levels of the order of the permissible exist in the laboratory area immediately above the accelerator, which is a public unregulated area, it was recommended either that classes be held during the time when the accelerator is not operating of that the area in which significant (less than 10 per cent of the permissible) neutron levels are detected be controlled and excluded. It was suggested that a sign be placed at this point indicating that levels higher than the permissible exist at this point when the machine is operating.

3. It was recommended that further shielding be added if the beam current now used ( 3 $\mu \mathrm{a}$ of deuterium on a tritium target, or about $10 \mu \mathrm{a}$ of deuterium on a deuterated target) should be doubled. In this case the added shielding should be sufficient to reduce the expected stray radiation fields outside the shielding to 25 per cent of the permissible in order to allow for further increases in the beam current. The penetrating power of the D-D neutrons was not found to be very different from that of $D-T$ neutrons. Estimates of the half-value layers were $12 \mathrm{~cm}$ for the $D-T$ neutrons and $8.8 \mathrm{~cm}$ for the $D-D$ neutrons.

4. Since it is possible for the accelerator vault (beam area) to be entered while the machine is operating without the operator's attention being attracted, it was recommended that an interlock be installed at the vault entrance which would either shut down the machine if a person should attempt to enter the vault or prevent entrance to the vault while the machine is in operation.

5. Because of the high $x$-ray levels at the east side of the Van de Graaff tank, it was recommended that a warning sign be placed near that point.

\subsection{University of Chicago}

(a) Synchrocyclotron. Radiation measurements were made near the synchrocyclotron at the locations indicated in Fig. 30. During the survey 460-Mev protons were used to bombard first a beryllium and next an aluminum-palladium target. The latter target condition produced the maximum operating condition in terms of the fluxes produced. Table 35 summarizes the measurements made with several instruments. All the $x$-ray levels were insignificant. In several locations the neutron energies were some what degraded; consequently, estimates of the fraction of the maximum permissible quantities, based on Po-Be calibrations, were probably high (e.g., locations 14, 15, and 16, Fig. 30). Fast neutron fluxes in excess of the maximum permissible were found at locations 1, 3, 5, 6, and 7. In the east corridor, particularly at location 3, a considerable fast neutron flux was found, in addition to the thermal flux; therefore, the MPD rate fractions given in the Table 35 for these locations are probably realistic.

The following recommendations were made:

1. It was suggested that warning signs be erected in the east corridor.

2. It was suggested that careful consideration of recently proposed changes in the maximum permissible radiation doses should influence changes to be made in the experimental area. Suggested shield design criteria are presented in Sec. 7.

(b) Betatron. The $100-\mathrm{Mev}$ betatron is located in the laboratory building basement to the south of the synchrocyclotron. Measurements were made at the locations indicated in Fig. 30 for both north and south beam operation. Table 36 summarizes the estimated $x$-ray and neutron levels, which were very low in all locations. No recommendations were made.

(c) Cockcroft-Walton Accelerator. The Cockcroft-Walton accelerator is located in the basement of the Fermi Laboratory (Fig. 31). The console and the laboratory area into which 


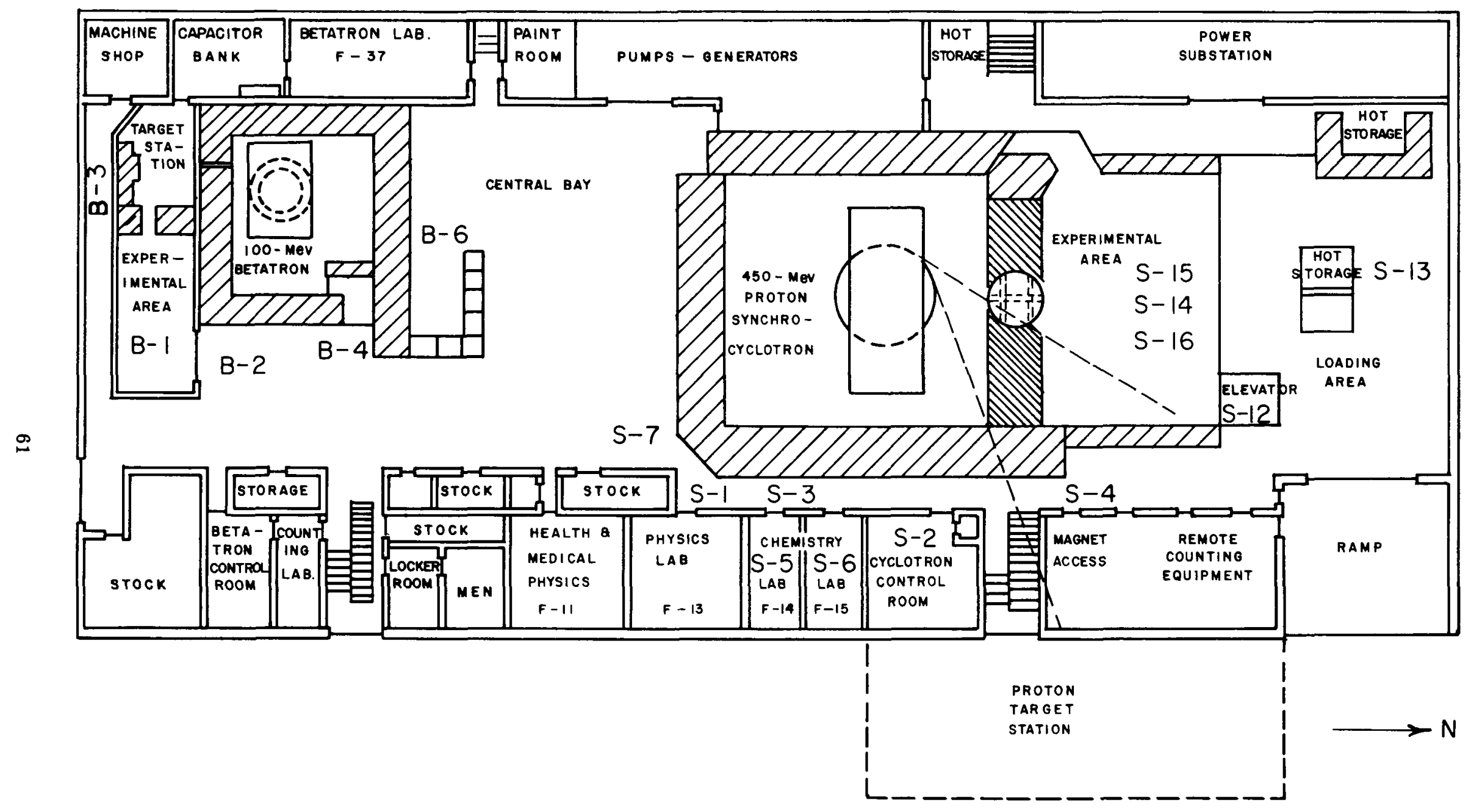

Fig. 30-University of Chicago synchrocyclotron and betatron layout, September 1956. 
Table 35-RADIATION LEVELS AT UNIVERSITY OF CHICAGO SYNCHROCYCLOTRON (SEPTEMBER 1956)

\begin{tabular}{|c|c|c|c|c|c|c|c|c|c|c|}
\hline \multirow[b]{2}{*}{ Location } & \multirow[b]{2}{*}{ Description } & \multirow{2}{*}{$\begin{array}{l}\text { Juno, } \\
\mathrm{mr} / \mathrm{hr}\end{array}$} & \multicolumn{2}{|c|}{ Thompson } & \multirow{2}{*}{$\begin{array}{l}\text { Hornyak, } \\
\mathrm{n} / \mathrm{cm}^{2}-\mathrm{sec}\end{array}$} & \multicolumn{2}{|c|}{$\mathrm{BF}_{3}-\mathrm{CO}_{2}$} & \multicolumn{2}{|c|}{ Tissue dose rate, mrep $/ \mathrm{hr}$} & \multirow{2}{*}{$\begin{array}{l}\text { Fraction } \\
\text { of MPD }\end{array}$} \\
\hline & & & $\mathrm{n}_{\mathrm{f}} / \mathrm{cm}^{2}-\mathrm{sec}$ & $\mathrm{n}_{\mathrm{t}} / \mathrm{cm}^{2}-\mathrm{sec}$ & & $\mathrm{n} / \mathrm{cm}^{2}-\mathrm{sec}$ & $\mathrm{mr} / \mathrm{hr}$ & Calc. & Obs. & \\
\hline 1 & $\begin{array}{l}\text { East corridor, main level } \\
\text { with } 6-\mathrm{mm} \text { Be target }\end{array}$ & 1 & 54.5 & 108 & & 31.9 & 0.6 & 1.1 & 0.7 & 1.10 \\
\hline 1 & $\begin{array}{l}\text { Row with } 2-\mathrm{mm} \mathrm{Al} \text { over } \\
\text { Pd target }\end{array}$ & 1 & 60.0 & 120 & 58 & 43.8 & 0.8 & 1.6 & 0.9 & 1.50 \\
\hline 2 & Console & 0 & 1.6 & 120 & $<10$ & 15.1 & 0.2 & 0.4 & 0.1 & 0.51 \\
\hline $2 a$ & Under console table & & 1.6 & 720 & & & & & & \\
\hline 3 & $\begin{array}{l}\text { East corridor opposite } \\
\text { Room F14 }\end{array}$ & 2 & 120 & 300 & 88 & 75.1 & 1.4 & 2.6 & 1.8 & 2.58 \\
\hline 4 & $\begin{array}{l}\text { East corridor opposite } \\
\text { Room F17 }\end{array}$ & 0 & 0.5 & 18 & 0 & 2.9 & 0.1 & 0.1 & 0.02 & 0.11 \\
\hline 5 & Room F14, work table & 1 & 65.4 & 60 & 41 & 22.5 & 0.5 & 0.9 & 0.9 & 0.78 \\
\hline 6 & Room F15 & 1 & 43.6 & 90 & 24 & 24.4 & 0.5 & 0.9 & 0.6 & 0.84 \\
\hline 7 & Work area to $S E$ & 0 & 38.2 & 66 & 20 & 18.5 & 0.5 & 0.8 & 0.8 & 0.66 \\
\hline 8 & Balcony at $\mathrm{SE}$ corner & 1 & 7.1 & 30 & $<10$ & 6.9 & 0.1 & 0.2 & 0.1 & 0.23 \\
\hline 9 & Drafting room (160) & & & & $<10$ & & & & & \\
\hline 10 & $\begin{array}{l}\text { Gallery opposite stair } \\
\text { well }\end{array}$ & 1 & 0.5 & 18 & $\sim 0$ & 0.7 & 0.05 & 0.1 & 0.1 & 0.03 \\
\hline 11 & $\begin{array}{l}\text { Gallery between Rooms } \\
114 \text { and } 115\end{array}$ & $<1$ & 0 & 0 & 0 & 0.4 & 0.1 & 0.1 & 0.04 & 0.03 \\
\hline 12 & Elevator, top of vault & 0.5 & 1.1 & 12 & 0 & 0.4 & 0.05 & 0.06 & 0.02 & 0.02 \\
\hline 13 & North vault loading area & 1 & 0.5 & 0 & 0 & 0.3 & 0.1 & 0.1 & 0.02 & 0.02 \\
\hline 14 & $\begin{array}{l}\text { Experimental area at } \\
\text { table }\end{array}$ & 1 & 0.5 & 144 & 0 & 38.4 & 0.1 & 0.7 & 0.1 & 1.23 \\
\hline 15 & $\begin{array}{l}\text { Experimental area, } \\
\text { facing cyclotron }\end{array}$ & 1 & 0.3 & 132 & & 37.4 & 0.4 & 1.0 & 0.3 & 2.24 \\
\hline 16 & $\begin{array}{l}\text { Experimental area, } \\
1 \text { meter to left }\end{array}$ & 0.5 & 1.1 & 108 & 0 & 37.1 & 0.1 & 0.7 & 0.1 & 1.19 \\
\hline
\end{tabular}


Table 36-RADIATION LEVELS AT UNIVERSITY OF CHICAGO BETATRON (SEPTEMBER 1956)

\begin{tabular}{|c|c|c|c|c|c|c|c|c|c|}
\hline \multirow[b]{2}{*}{ Location } & \multirow[b]{2}{*}{ Description } & \multirow{2}{*}{$\begin{array}{l}\text { Juno, } \\
\mathrm{mr} / \mathrm{hr}\end{array}$} & \multicolumn{2}{|c|}{ Thompson } & \multicolumn{2}{|c|}{$\mathrm{BF}_{3}-\mathrm{CO}_{2}$} & \multicolumn{2}{|c|}{ Tissue dose rate, mrep/hr } & \multirow{2}{*}{$\begin{array}{l}\text { Fraction } \\
\text { of MPD }\end{array}$} \\
\hline & & & $\overbrace{\mathrm{n}_{\mathrm{f}} / \mathrm{cm}^{2}-\mathrm{sec}}$ & $\mathrm{n}_{\mathrm{t}} / \mathrm{cm}^{2}-\mathrm{sec}$ & $\mathrm{n} / \mathrm{cm}^{2}-\mathrm{sec}$ & $\overline{\mathrm{mr} / \mathrm{hr}}$ & Calc. & Obs. & \\
\hline 1 & $\begin{array}{l}\text { South experimental } \\
\text { area }\end{array}$ & 1 & 0 & 0 & 0 & 0.37 & 0.37 & 0.04 & 0.05 \\
\hline 1 & $\begin{array}{l}\text { With scatterer in } \\
\text { beam }\end{array}$ & 1 & 0 & 0 & 0 & 0.507 & 0.507 & 0.255 & 0.07 \\
\hline 2 & $\begin{array}{l}\text { Between control room } \\
\text { and vault wall }\end{array}$ & 1 & 5.45 & 0 & 0 & 0.456 & 0.456 & 0.157 & 0.06 \\
\hline 3 & $\begin{array}{l}\text { South side of vault, } \\
\text { beam end out }\end{array}$ & 1 & 1.09 & 0 & 0 & 0.507 & 0.507 & 0.471 & 0.07 \\
\hline 4 & North door & 0 & 0.55 & 0 & 0 & 0.507 & 0.507 & 0.03 & 0.07 \\
\hline 5 & On mezzanine & 1 & & & & & & & \\
\hline 6 & North end of vault & 0 & & & 4.3 & 0.286 & 0.354 & 0.137 & 0.17 \\
\hline 6 & Beam out north end & $<1$ & 0 & 0 & 0 & 0.253 & 0.253 & 0.157 & 0.03 \\
\hline
\end{tabular}

Table 37 -RADIATION LEVELS AT UNIVERSITY OF CHICAGO COCKCROFT-WALTON ACCELERATOR (SEPTEMBER 1956)

(5- $\mu$ a Deuteron Beam, No Target)

\begin{tabular}{|c|c|c|c|c|c|c|c|c|c|}
\hline \multirow[b]{2}{*}{ Location } & \multirow[b]{2}{*}{ Description } & \multirow{2}{*}{$\begin{array}{l}\text { Juno, } \\
\mathrm{mr} / \mathrm{hr}\end{array}$} & \multicolumn{2}{|c|}{ Thompson } & \multicolumn{2}{|c|}{$\mathrm{BF}_{3}-\mathrm{CO}_{2}$} & \multicolumn{2}{|c|}{ Tissue dose rate, $\mathrm{mrep} / \mathrm{hr}$} & \multirow{2}{*}{$\begin{array}{l}\text { Fraction } \\
\text { of MPD }\end{array}$} \\
\hline & & & $\mathrm{n}_{\mathrm{f}} / \mathrm{cm}^{2}-\mathrm{sec}$ & $\mathrm{n}_{\mathrm{t}} / \mathrm{cm}^{2}-\mathrm{sec}$ & $\mathrm{n} / \mathrm{cm}^{2}-\mathrm{sec}$ & $\mathrm{mr} / \mathrm{hr}$ & Calc. & Obs. & \\
\hline 1 & Opposite beam, port & 0.1 & 0.545 & 9.0 & 5.73 & 0.038 & 0.129 & 0.196 & 0.187 \\
\hline 2 & Gallery over CW & 35 & 0.85 & 360 & 73.8 & 10.5 & 11.7 & 22.1 & 1.40 \\
\hline 2 & Behind closed door & 1.5 & & & & & & & \\
\hline 3 & $\begin{array}{l}\text { In hall outside } \\
\text { accelerator area }\end{array}$ & 0 & 0.545 & 6 & 18.0 & 0.0118 & 0.298 & 0.0196 & 0.574 \\
\hline 4 & $\begin{array}{l}\text { Room behind target } \\
\text { room }\end{array}$ & 0.1 & 0.545 & 12 & 16.7 & 0.419 & 0.684 & 0.00979 & 0.597 \\
\hline 4 & $\begin{array}{l}\text { Room behind target } \\
\text { room with Be target }\end{array}$ & 0 & 0.545 & 0 & 18.7 & 0 & 0.297 & 0.01959 & 0.595 \\
\hline 1 & With Be target & 0 & 4.36 & 12.0 & 29.6 & 0.0172 & 0.487 & 0.137 & 0.944 \\
\hline 3 & With Be target & 0 & 0.545 & 9.00 & 17.4 & 0 & 0.276 & 0.0255 & 0.553 \\
\hline 5 & Basement & 1 & & & & & & & \\
\hline 6 & $\begin{array}{l}\text { Second floor over } \\
\text { machine }\end{array}$ & 1 & 0.272 & 0 & & & & & \\
\hline
\end{tabular}


the beam emerges are on the first floor. The Cockeroft-Walton was operated with a 5- $\mu$ a deuteron beam for both the no target and the beryllium target conditions.

Survey results appear in Table 37. Radiation levels were minimal, and consequently no recommendations were made.

\subsection{University of Illinois Medical School}

The University of Illinois Medical School 25-Mev betatron is located in the basement of a laboratory building connected to the hospital by an underpass. Figure 32 shows the floor plan of the area surrounding the accelerator, with the locations numbered where radiation measurements were made. Further measurements were made in the loading area adjacent to, and directly above, the betatron vault and also in the nurses' quarters across the courtyard. Readings were taken in the nurses' basement lounge, as well as in the first and second floor rooms facing the loading area. During the survey the betatron was operated at $22.5 \mathrm{Mev}$, the beam intensity being $75 \mathrm{r} / \mathrm{min}$ at $84 \mathrm{~cm}$ from the target.

Table 38 lists the observed neutron and gamma-ray intensities at the locations labeled on Figs. 32 and 33. Readings higher than the maximum permissible were found at several points. Three instruments recorded a high neutron flux, both fast and thermal, in the passageway in front of the door to the betatron vault. This high level has at least five times the maximum permissible flux of $\approx 30 \mathrm{n} / \mathrm{cm}^{2}$-sec for fast neutrons.

Considerably higher readings were recorded at the face of the concrete loading platform directly above the betatron vault. In a localized area a radiation intensity of approximately 40 times the maximum permissible was observed (location 7), whereas in regions a few feet away the intensity was considerably lower but still above the permissible (i.e., location 18). These readings indicated that a narrow beam of neutrons and gamma rays was coming directly from the betatron through the thinnest portion of the concrete shield. This beam was apparently directed toward the nurses' quarters. Measurements made there indicated the presence of levels in excess of the permissible in the first floor shower room near the stair well. Measurable intensities somewhat less than the permissible were found at several other locations on the first two floors.

It should be noted that the maximum permissible levels referred to, and which appear in Table 38, are applicable to a $40-\mathrm{hr} / \mathrm{wk}$ occupancy time in a regulated area. For unregulated areas, such as the courtyard and nurses' quarters, weekly permissible levels should be reduced by a factor of 10 , and thus the MPD fractions for these areas should be increased by the same factor. Personnel occupancy time in radiation areas is an important factor to be considered before evaluating the significance of the radiation levels encountered.

An examination of the data indicates inconsistencies in some of the neutron flux measurements. It is felt that this is due primarily to a pile-up effect, resulting in spurious counts produced in the hand survey instruments by the pulsed radiation from the betatron. In this case the ionization chambers would be the most reliable. Those estimates of the neutron flux, based primarily on the portable survey meters where pile-up was thought to have a significant effect, are indicated in Table 38 by an asterisk. Wherever possible, permissible levels are estimated from the readings of the $\mathrm{BF}_{3}-\mathrm{CO}_{2}$ ionization chamber combination since this was not affected by gamma-ray pile-up.

In order to reduce the radiation levels observed in the loading area and nurses' quarters, it was recommended that additional concrete shielding be placed at location 7 along the ground next to the loading dock. To reduce these levels to the permissible, this additional concrete should be at least $10 \mathrm{ft}$ long and $3 \mathrm{ft}$ thick and about the same height as the loading dock, extending in from the outer end of the dock. A gamma survey should be undertaken after installation to check the effectiveness of the additional shielding.

It was recommended that all personnel involved in the routine operation of the betatron wear neutron-gamma film badges.

Because of the high neutron fluxes observed in the passage in front of the door to the betatron vault, it was recommended that this area be enclosed or otherwise protected from the intrusion of personnel during the operation of the betatron. 


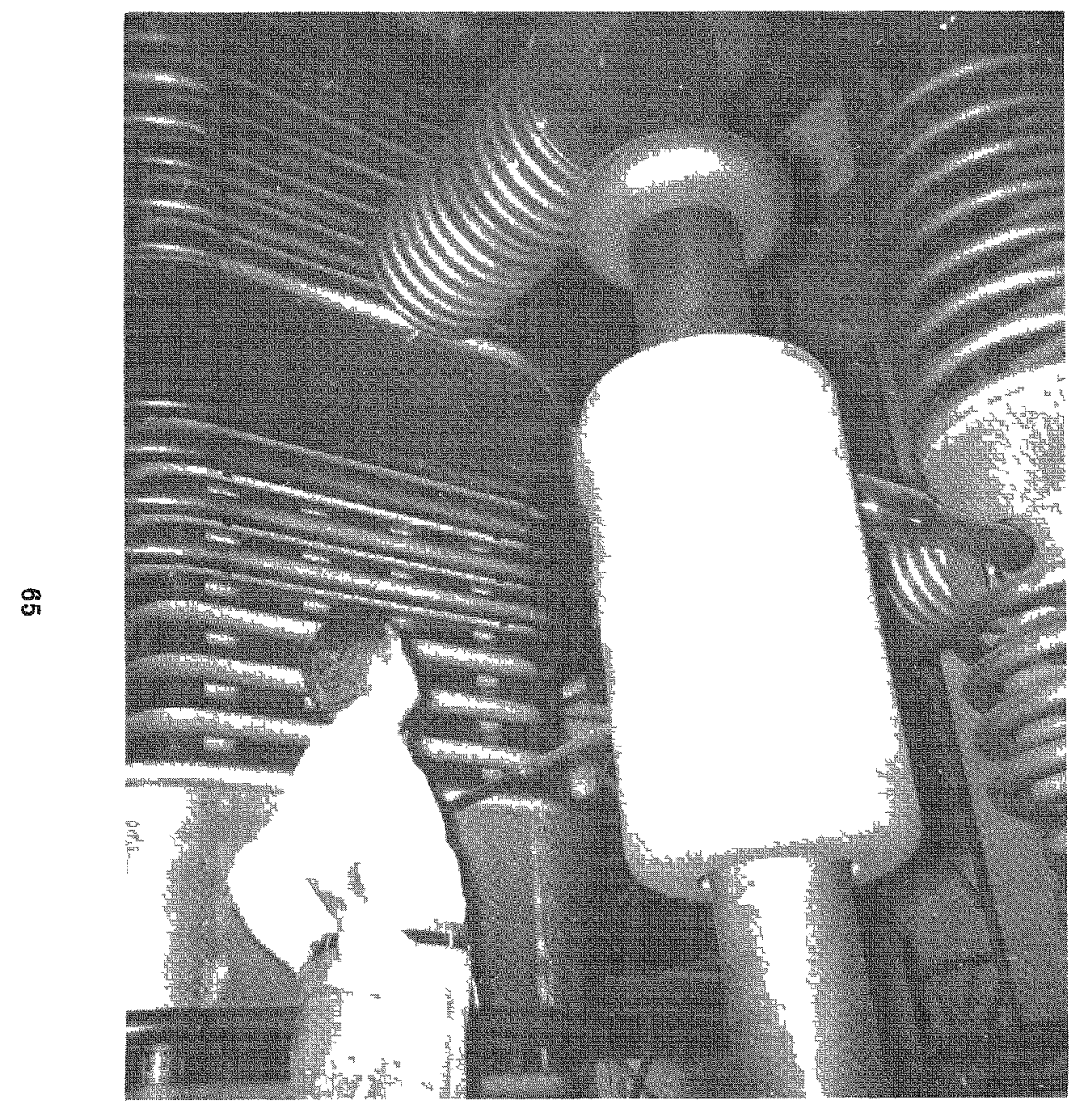

Fig. 31 - University of Chicago Cockcroft-Waiton accelerator.

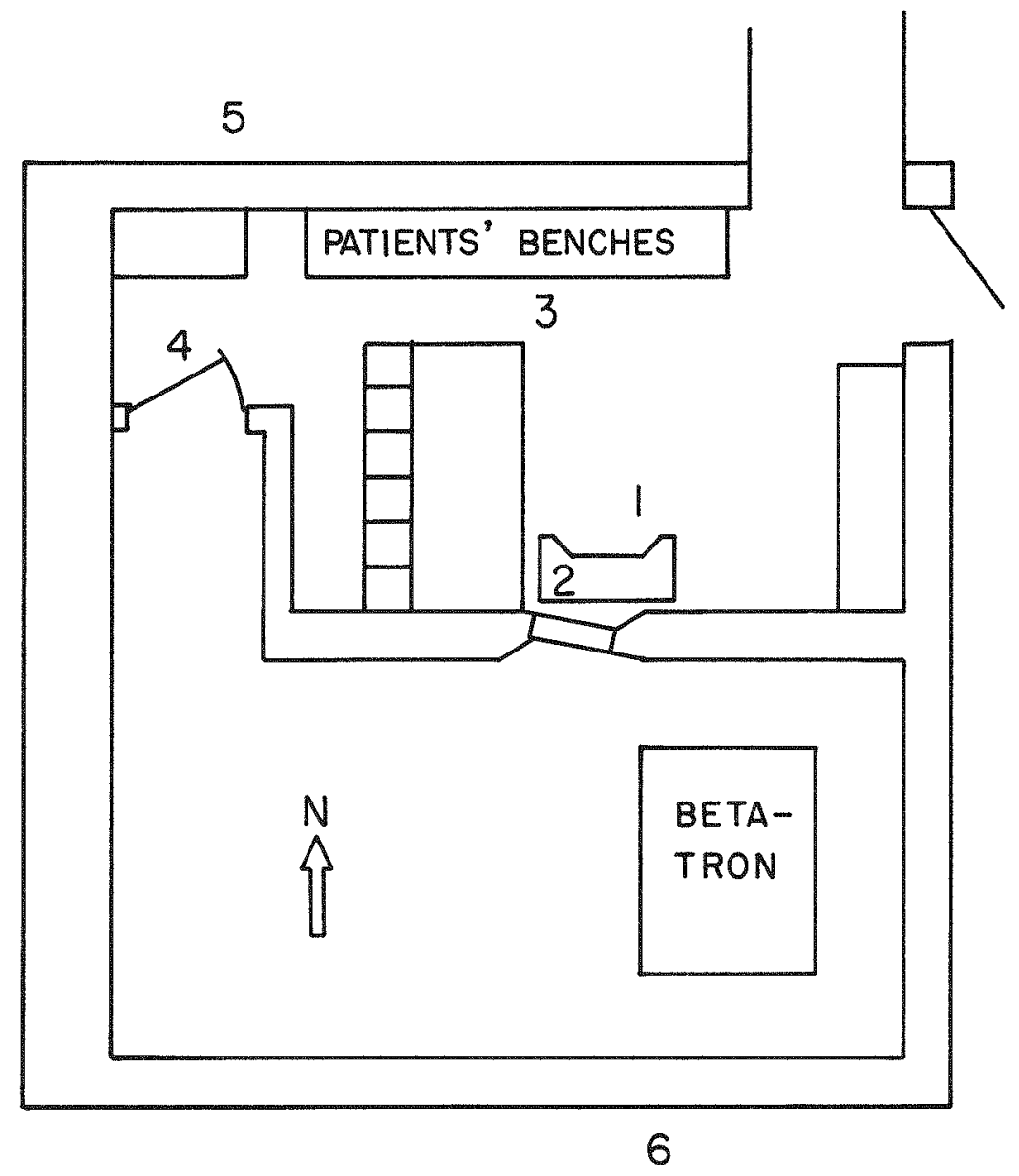

Fig. 32-University of Illınoıs Medıcal School betatron layout. 
Table 38-RADIATION LEVELS AT UNIVERSITY OF ILLINOIS MEDICAL SCHOOL BETATRON (SEPTEMBER 1956)

\begin{tabular}{|c|c|c|c|c|c|c|c|c|c|c|}
\hline \multirow[b]{2}{*}{ Location } & \multirow[b]{2}{*}{ Description } & \multirow{2}{*}{$\begin{array}{l}\text { Juno, } \\
\mathrm{mr} / \mathrm{hr}\end{array}$} & \multirow{2}{*}{$\begin{array}{c}\mathrm{ZnS} \\
\mathrm{n} / \mathrm{cm}^{2}-\mathrm{sec}\end{array}$} & \multicolumn{2}{|c|}{ Thompson } & \multicolumn{2}{|c|}{$\mathrm{BF}_{3}-\mathrm{CO}_{2}$} & \multicolumn{2}{|c|}{ Tissue dose rate, mrep $/ \mathrm{hr}$} & \multirow{2}{*}{$\begin{array}{l}\text { Fraction } \\
\text { of MPD }\end{array}$} \\
\hline & & & & $\mathrm{n}_{\mathrm{f}} / \mathrm{cm}^{2}-\mathrm{sec}$ & $\mathrm{n}_{\mathrm{t}} / \mathrm{cm}^{2}-\mathrm{sec}$ & $\mathrm{n} / \mathrm{cm}^{2}-\mathrm{sec}$ & $\mathrm{mr} / \mathrm{hr}$ & Calc. & Obs. & \\
\hline 1 & $\begin{array}{l}\text { Control room opposite console } \\
\text { ( } \mathrm{Ra}-\mathrm{Be} \text { background) }\end{array}$ & 2 & 0 & 0 & 6 & 0.09 & 0.025 & 0.026 & 0.020 & 0.00619 \\
\hline 1 & & 1 & $<10$ & 22 & 90 & 13.8 & 0.25 & 0.47 & 0.29 & 0.472 \\
\hline 2 & On console & 1 & $<10$ & 6.5 & 120 & & & & & 0.417 \\
\hline 2 & $\begin{array}{l}\text { At window over console } \\
\text { hot spot }\end{array}$ & & 30 & & & & & & & 1.0 \\
\hline 2 & Phantom in beam & 1 & $<10$ & 6.5 & 120 & & & & & 0.417 \\
\hline 3 & Entrance to betatron hall & 0 & 0 & 11 & 102 & 11.9 & 0.23 & 0.42 & 0.29 & 0.409 \\
\hline 4 & $\begin{array}{l}\text { Outside door to } \\
\text { betatron vault }\end{array}$ & 4.5 & $>250^{*}$ & $981 *$ & 1500 & 161 & 3.8 & 6.4 & 4.1 & 6.04 \\
\hline 5 & $\begin{array}{l}\text { In workroom opposite } \\
\text { location } 4\end{array}$ & 1 & & 1.1 & 12 & & & & & 0.177 \\
\hline 6 & Cellar, south wall of vault & 0.5 & $<10$ & 1.6 & 0 & & & & & 0.120 \\
\hline 7 & Courtyard, edge of vault & 70 & $>250^{*}$ & $872 *$ & 9600 & & & & & $\sim 40$ \\
\hline 8 & Courtyard, top of vault & 0 & 0 & 0.5 & 30 & & & & & 0.0333 \\
\hline 9 & $\begin{array}{l}\text { Nurses' quarters, first floor } \\
\text { shower room, at window }\end{array}$ & 3 & $90^{*}$ & $654^{*}$ & 18 & & & & & 3.41 \\
\hline 10 & $\begin{array}{l}\text { Nurses' quarters, Room 136, } \\
\text { at window }\end{array}$ & 1 & $<10$ & $136^{*}$ & 18 & & & & & $\sim 0.3$ \\
\hline 11 & $\begin{array}{l}\text { Nurses' quarters, Room } 134 \text {, } \\
\text { at window }\end{array}$ & 1 & $<10$ & $13.6^{*}$ & 18 & & & & & $\sim 0.2$ \\
\hline 12 & $\begin{array}{l}\text { Nurses' quarters, Room 132, } \\
\text { at window }\end{array}$ & 0 & $<10$ & 0.5 & 6 & & & & & 0.0167 \\
\hline 13 & $\begin{array}{l}\text { Nurses' quarters, first floor } \\
\text { stair well }\end{array}$ & 1 & $<10$ & 0.5 & 6 & & & & & 0.150 \\
\hline 14 & $\begin{array}{l}\text { Nurses' quarters, second floor } \\
\text { shower room, at window }\end{array}$ & 1 & $<10$ & 10.4 & 18 & & & & & 0.490 \\
\hline 15 & $\begin{array}{l}\text { Nurses' quarters, Room } 236 \text {, } \\
\text { at window }\end{array}$ & 1 & $<10$ & 5.5 & 12 & & & & & 0.323 \\
\hline 16 & $\begin{array}{l}\text { Nurses' quarters, outside first } \\
\text { floor shower room }\end{array}$ & 8 & $140^{*}$ & $817^{*}$ & 18 & & & & & 5.74 \\
\hline 17 & $\begin{array}{l}\text { Nurses' quarters, basement } \\
\text { recreation room }\end{array}$ & 1 & $<10$ & 0.5 & 6 & & & & & 0.153 \\
\hline 18 & $\begin{array}{l}\text { Courtyard, adjacent to } \\
\text { location } 7\end{array}$ & 20 & & & & 4.9 & 15.4 & 15.5 & 15.5 & 2.21 \\
\hline
\end{tabular}

*Estimates of the neutron flux, based primarily on the portable survey meters where pile-up was thought to have a significant effect. 

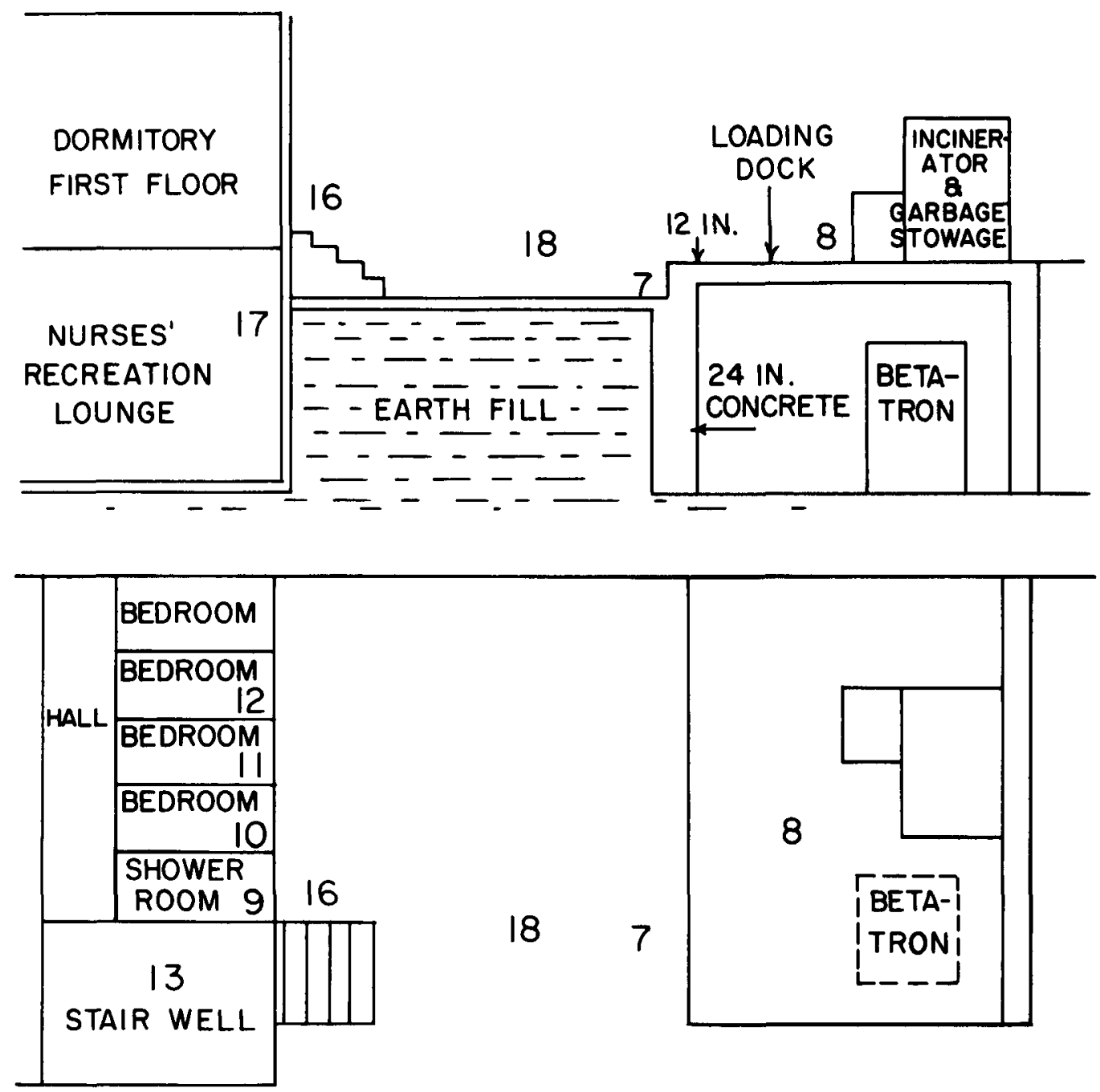

PARKING LOT

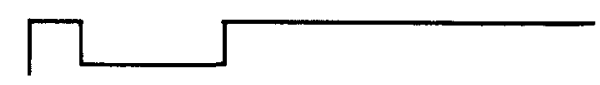

Fig. 33-University of Illinois Medical School betatron, courtyard and adjacent area.

\subsection{University of Michigan}

Two accelerators were surveyed at Michigan: a cyclotron and an 80-Mev electron synchrotron. The cyclotron is located on the furst level of the Randall Laboratory basement. Measurements were made at the location appearing in Fig. 34, as well as on the floor above (Fig. 35). Radiation levels were examined during three target conditions and a beam of $8-\mathrm{Mev}$ deuterons.

1. Beryllium probe without a target: beam current $=10 \mu \mathrm{a}$.

2. Same as above without a probe.

3. Mylar target, no probe: beam current $=2 \mu \mathrm{a}$.

The levels encountered are summarized in Tables 39 to 41 . The last column (Fraction of $M P D)$ lists the ratio, observed neutron flux divided by the maximum permissible flux. The reported fluxes are in terms of Po-Be neutrons, hence the maximum permissible flux is 30 $\mathrm{n} / \mathrm{cm}^{2}$-sec. However, the observed tissue dose rate is always less than the predicted; therefore, 


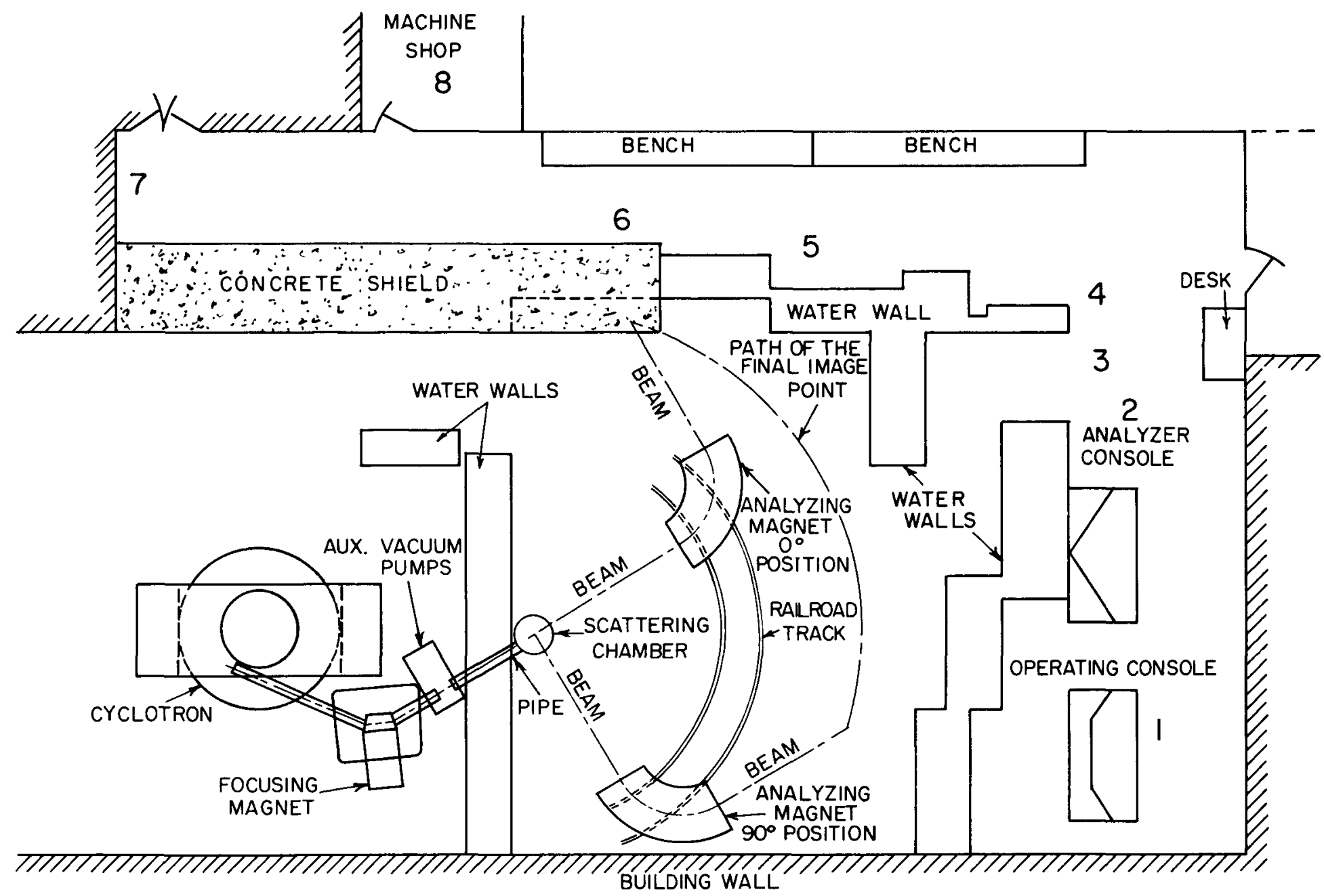

Fig. 34-University of Michigan cyclotron layout, December 1956. 


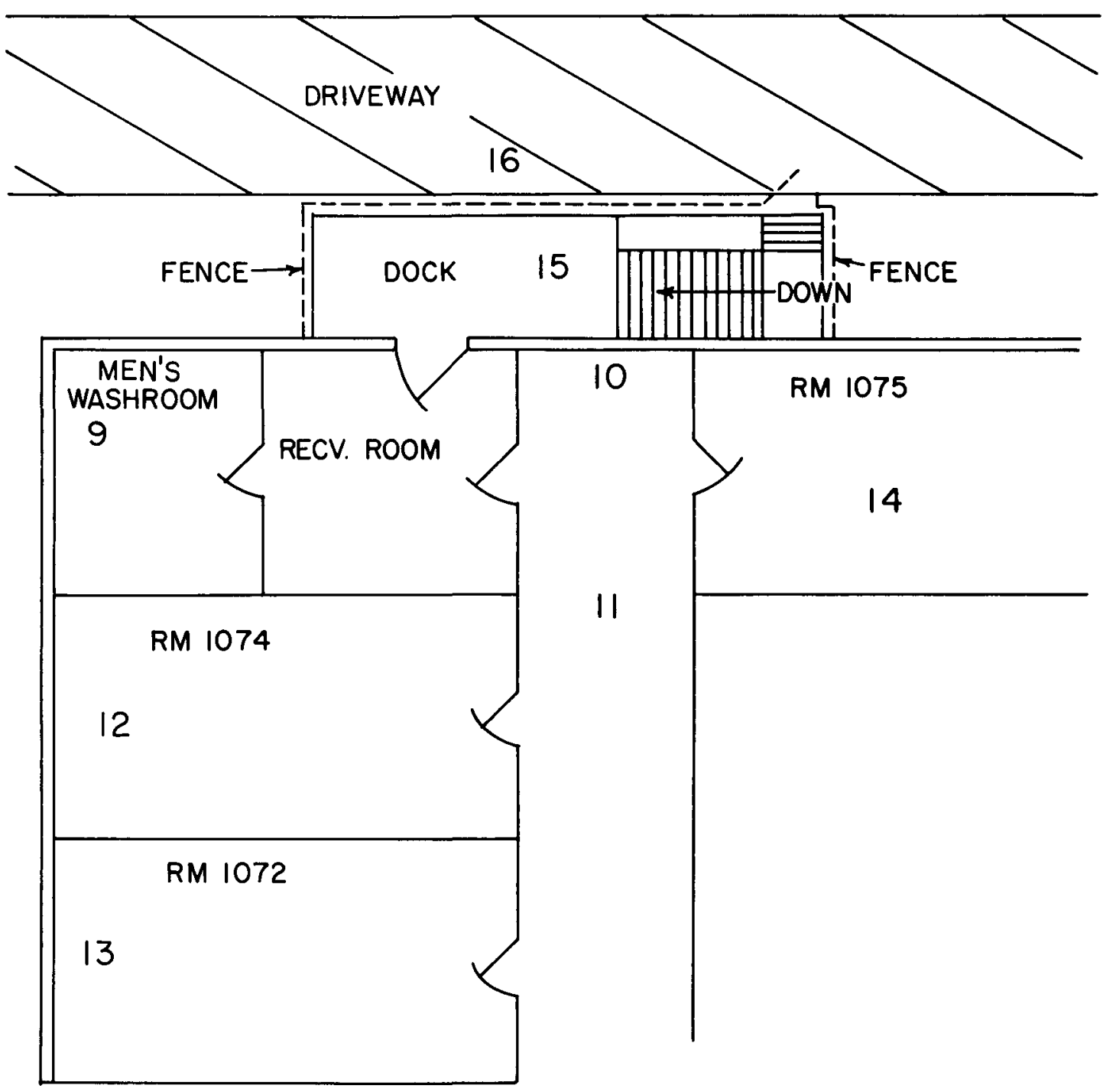

Fig. 35-University of Michigan, floor above cyclotron, December 1956 (not to scale).

it is obvious that the neutron energies are less than those of Po-Be neutrons. Irrespective of this conservatism the fluxes in locations 6,7 , and 8 were high enough to constitute a problem. Particularly important are the levels at location 9, an essentially unregulated area, and locations 15 and 16 (Fig. 36).

Two recommendations were made (1) neutron film badges should be used by all cyclotron personnel and (2) additional shielding should be installed to reduce the high neutron levels.

The survey of the synchrotron was made during the interaction of $80-\mathrm{Mev}$ electrons with a tungsten target. The resulting beam was about $5 \mathrm{rhm}$. The results for the locations in Fig. 37 are shown in Table 42.

No areas were found where radiation levels exceeded the maximum permissible, and consequently no recommendations were made. 
Table 39-SUMMARY OF RADIATION MEASUREMENTS AT UNIVERSITY OF MICHIGAN CYCLOTRON (DECEMBER 1956) (8-Mev Deuterons on Beryllium Probe, $10 \mu \mathrm{a}$, No Target)

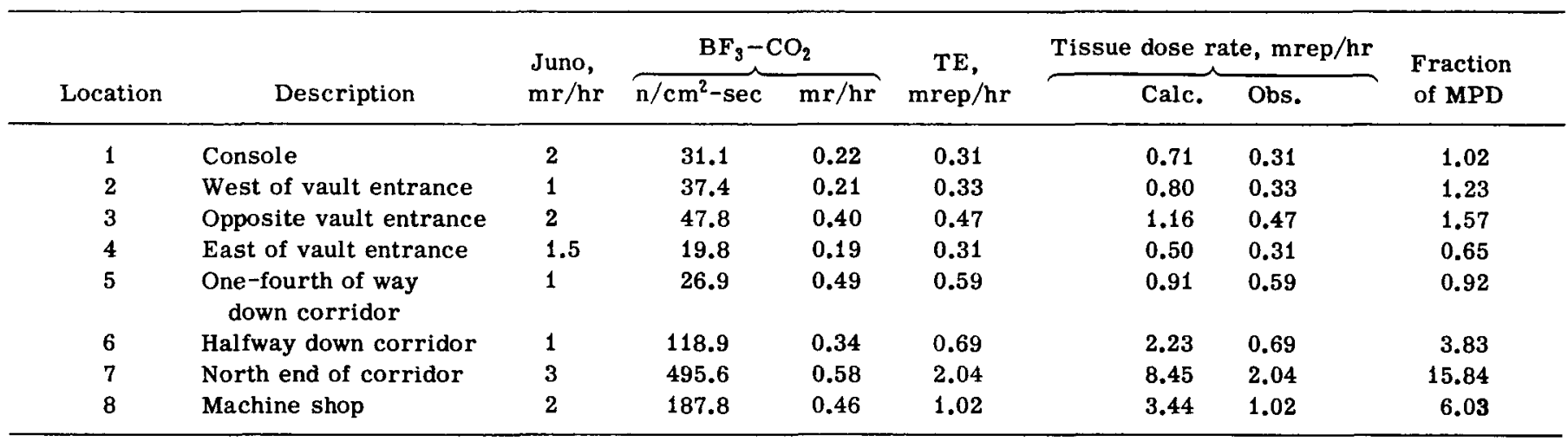

Table 40-SUMMARY OF RADIATION MEASUREMENTS AT UNIVERSITY OF MICHIGAN CYCLOTRON (DECEMBER 1956) (8-Mev Deuterons, $10 \mu \mathrm{a}$, No Target or Probe)

\begin{tabular}{|c|c|c|c|c|c|c|c|c|}
\hline \multirow[b]{2}{*}{ Location } & \multirow[b]{2}{*}{ Description } & \multirow{2}{*}{$\begin{array}{l}\text { Juno, } \\
\mathrm{mr} / \mathrm{hr}\end{array}$} & \multicolumn{2}{|c|}{$\mathrm{BF}_{3}-\mathrm{CO}_{2}$} & \multirow{2}{*}{$\begin{array}{c}\mathrm{TE}, \\
\mathrm{mrep} / \mathrm{hr}\end{array}$} & \multicolumn{2}{|c|}{ Tissue dose rate, $\mathrm{mrep} / \mathrm{hr}$} & \multirow{2}{*}{$\begin{array}{l}\text { Fraction } \\
\text { of MPD }\end{array}$} \\
\hline & & & $\mathrm{n} / \mathrm{cm}^{2}-\mathrm{sec}$ & $\mathrm{mr} / \mathrm{hr}$ & & Calc. & Obs. & \\
\hline 1 & Console & 1 & 5.69 & 0.10 & 0.04 & 0.19 & 0.04 & 0.19 \\
\hline 2 & West of vault entrance & 1 & 8.02 & 0.09 & 0.10 & 0.22 & 0.10 & 0.27 \\
\hline 3 & Opposite vault entrance & 1 & 14.3 & 0.10 & 0.14 & 0.33 & 0.14 & 0.47 \\
\hline 4 & East of vault entrance & 1 & 11.2 & 0.09 & 0.14 & 0.27 & 0.14 & 0.38 \\
\hline 5 & $\begin{array}{l}\text { One-fourth of way } \\
\text { down corridor }\end{array}$ & 1 & 19.2 & 0.15 & 0.24 & 0.45 & 0.24 & 0.63 \\
\hline 6 & Halfway down corridor & 1.5 & 97.2 & 0.13 & 0.41 & 1.67 & 0.41 & 3.11 \\
\hline 7 & North end of corridor & 2.5 & 332.6 & 0.33 & 1.36 & 5.60 & 1.36 & 10.62 \\
\hline 8 & Machine shop & 1.5 & 128.4 & 0.27 & 0.87 & 2.31 & 0.87 & 4.12 \\
\hline
\end{tabular}


Table 41 -SUMMARY OF RADIATION MEASUREMENTS AT UNIVERSITY OF MICHIGAN CYCLOTRON (DECEMBER 1956) (8-Mev Deuterons on Mylar Target, $2 \mu \mathrm{a}$ )

\begin{tabular}{|c|c|c|c|c|c|c|c|c|c|c|c|c|}
\hline \multirow[b]{2}{*}{ Location } & \multirow[b]{2}{*}{ Description } & \multirow{2}{*}{$\begin{array}{l}\text { Juno, } \\
\mathrm{mr} / \mathrm{hr}\end{array}$} & \multicolumn{2}{|c|}{ Thompson } & \multirow{2}{*}{$\begin{array}{l}\text { Hornyak, } \\
\mathrm{n} / \mathrm{cm}^{2}-\mathrm{sec}\end{array}$} & \multicolumn{2}{|c|}{ Nemo } & \multicolumn{2}{|c|}{$\mathrm{BF}_{3}-\mathrm{CO}_{2}$} & \multirow{2}{*}{$\begin{array}{c}\mathrm{TE}, \\
\mathrm{mrep} / \mathrm{hr}\end{array}$} & \multirow{2}{*}{$\begin{array}{c}\text { Calculated } \\
\text { TE, } \\
\text { mrep/hr }\end{array}$} & \multirow{2}{*}{$\begin{array}{l}\text { Fraction } \\
\text { of MPD }\end{array}$} \\
\hline & & & $\overparen{\mathrm{n}_{\mathrm{t}} / \mathrm{cm}^{2}-\mathrm{sec}}$ & $\mathrm{n}_{\mathrm{f}} / \mathrm{cm}^{2}-\mathrm{sec}$ & & $\mathrm{n}_{\mathrm{f}} / \mathrm{cm}^{2}-\mathrm{sec}$ & $\mathrm{n}_{\mathrm{t}} / \mathrm{cm}^{2}-\mathrm{sec}$ & $\overparen{\mathrm{n} / \mathrm{cm}^{2}-\mathrm{sec}}$ & $\mathrm{mr} / \mathrm{hr}$ & & & \\
\hline 1 & & 1.5 & & & & & & 39.2 & 0.28 & 0.31 & 0.90 & 1.28 \\
\hline 2 & & 1 & & & & & & 48.1 & 0.18 & 0.31 & 0.94 & 1.55 \\
\hline 3 & & 2 & & & & & & 99.9 & 0.42 & 0.57 & 2.01 & 3.23 \\
\hline 4 & & 1 & & & & & & 45.0 & 0.18 & 0.29 & 0.89 & 1.46 \\
\hline 5 & & 1 & & & & & & 62.3 & 0.32 & 0.49 & 1.31 & 2.02 \\
\hline 6 & & 2.5 & & & & & & 219.4 & 0.39 & 1.02 & 3.87 & 7.03 \\
\hline 7 & & 5 & & & & & & 815.8 & 0.80 & 3.26 & 13.75 & 26.05 \\
\hline 8 & & 1.5 & & & & & & 432.5 & 0.76 & 1.79 & 7.63 & 13.86 \\
\hline 9 & Second floor lavatory & 7 & 2,100 & 9.32 & 20 & 220 & 1,000 & & & & & 2.74 \\
\hline 10 & $\begin{array}{l}\text { North end of hallway, } \\
\text { second floor }\end{array}$ & 2 & 720 & 1.86 & $<10$ & 50 & 150 & & & & & 0.73 \\
\hline 11 & 7 meters south of 10 & 1 & 180 & 9.32 & $<10$ & 10 & 20 & & & & & 0.53 \\
\hline 12 & $\begin{array}{l}\text { Room } 1074, \text { second } \\
\text { floor }\end{array}$ & 3 & 6 & 0.31 & $\sim 10$ & 50 & 200 & & & & & 0.41 \\
\hline 13 & $\begin{array}{l}\text { Room } 1072, \text { second } \\
\text { floor }\end{array}$ & 1.5 & 72 & 1.24 & $<10$ & 10 & 10 & & & & & 0.28 \\
\hline 14 & $\begin{array}{l}\text { Room } 1075, \text { second } \\
\text { floor }\end{array}$ & 1 & 6 & 0.62 & $\sim 0$ & 20 & 10 & & & & & 0.16 \\
\hline 15 & $\begin{array}{l}\text { Former loading } \\
\text { platform }\end{array}$ & 45 & $>30,000$ & 111.8 & 185 & 20 & 20 & & & & & $>30.22$ \\
\hline 16 & Driveway & 5 & 4,200 & 4.35 & 28 & 20 & 20 & & & & & 3.58 \\
\hline
\end{tabular}




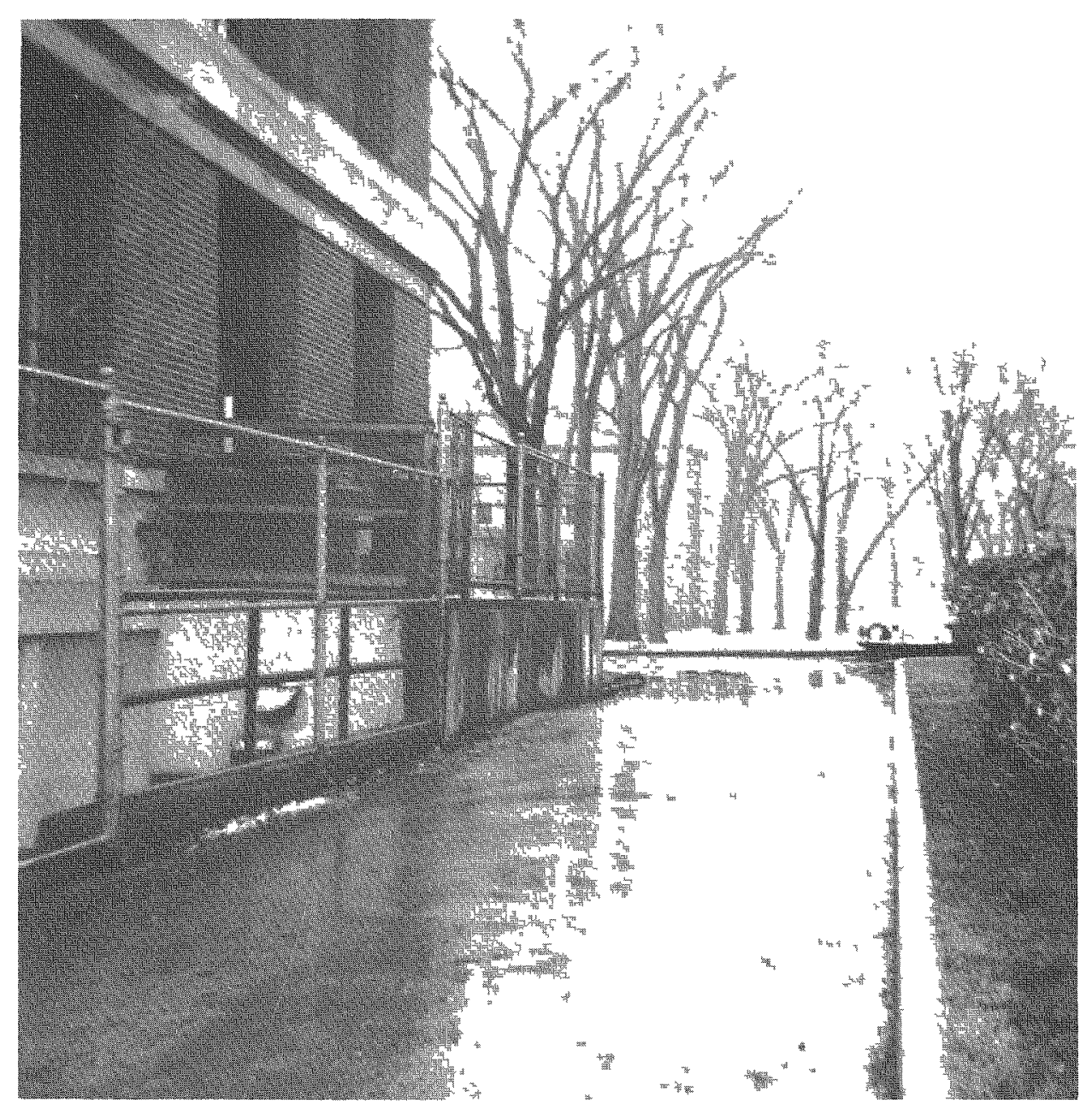

Fig. 36-University of Michigan, uncontrolled area (sidewalk).

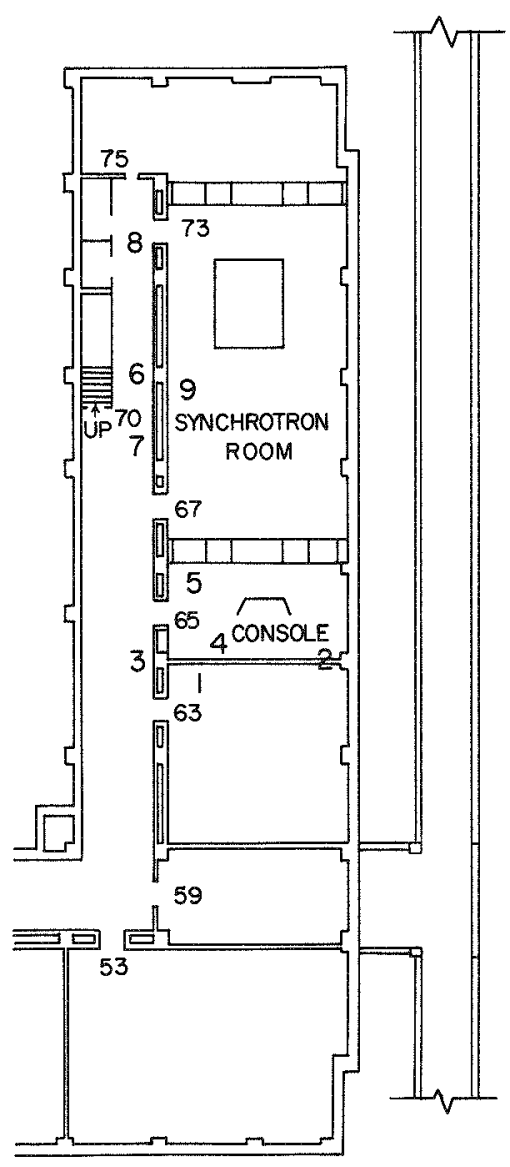

Fig. 37 - University of Michigan synchrotron layout, December 1956. 
Table 42-SUMMARY OF RADIATION LEVELS AT UNIVERSITY OF MICHIGAN SYNCHROTRON (DECEMBER 1956) (80-Mev Electrons on Tungsten Target, $5 \mathrm{r} / \mathrm{hr}$ at 1 Meter)

\begin{tabular}{|c|c|c|c|c|c|c|c|}
\hline \multirow[b]{2}{*}{ Location } & \multirow[b]{2}{*}{ Description } & \multirow{2}{*}{$\begin{array}{l}\text { Juno, } \\
\mathrm{mr} / \mathrm{hr}\end{array}$} & \multicolumn{2}{|c|}{$\mathrm{BF}_{3}-\mathrm{CO}_{2}$} & \multirow{2}{*}{$\begin{array}{l}\text { TE, } \\
\text { mrep/hr }\end{array}$} & \multirow{2}{*}{$\begin{array}{c}\text { Calculated } \\
\text { TE, } \\
\text { mrep/hr }\end{array}$} & \multirow{2}{*}{$\begin{array}{l}\text { Fraction } \\
\text { of MPD }\end{array}$} \\
\hline & & & $\mathrm{n} / \mathrm{cm}^{2}-\mathrm{sec}$ & $\mathrm{mrep} / \mathrm{hr}$ & & & \\
\hline 1 & Room 63 opposite beam & 1.75 & $\sim 0$ & 0.50 & 0.55 & 0.50 & 0.07 \\
\hline 2 & $\begin{array}{l}\text { Entrance to Room } 63 \\
\text { and control room }\end{array}$ & 1 & 0.59 & 0.10 & 0.14 & 0.11 & 0.03 \\
\hline 3 & $\begin{array}{l}\text { Outside hall between } \\
\text { Room } 63 \text { and control room }\end{array}$ & 0.75 & 0.88 & 0.08 & 0.09 & 0.09 & 0.04 \\
\hline 4 & Control room, console & 1 & 0.63 & 0.12 & 0.13 & 0.13 & 0.04 \\
\hline 5 & $\begin{array}{l}\text { Control room under } \\
\text { beam opening }\end{array}$ & 0.8 & 0.86 & 0.45 & 0.71 & 0.46 & 0.09 \\
\hline 6 & In hall opposite Room 67 & 1 & 1.73 & 0.02 & 0.09 & 0.05 & 0.06 \\
\hline 7 & In hall opposite Exit 70 & 1.5 & 12.62 & 0.37 & 0.61 & 0.57 & 0.45 \\
\hline 8 & In hall opposite Room 73 & 1 & 7.64 & 0.34 & 0.43 & 0.46 & 0.29 \\
\hline 9 & $\begin{array}{l}\text { On top of blockhouse, } \\
1 \mathrm{ft} \text { at } 80 \mathrm{Mev}\end{array}$ & & 23.88 & 2.41 & 6.72 & 2.79 & 1.08 \\
\hline 9 & At $30 \mathrm{Mev}$ & & 6.79 & 2.09 & 5.70 & 2.20 & 0.49 \\
\hline
\end{tabular}


It was concluded in Report NYO-4699 that accelerator workers, in general, are not receiving excessive radiation doses. The film badge summaries reported earlier ${ }^{1}$ and in Table 3 indicate that 10 to 25 per cent of accelerator personnel accounted for roughly 50 per cent of the radiation exposure entries appearing in the summaries. However, the inadequacy of existing neutron personnel monitoring techniques in the intermediate energy range, as well as the insufficient knowledge with regard to any detecting device in the high-energy ranges, implies that the film badges do not yield conservative estimates of an individual's radiation history. It is recommended then that particle accelerator personnel should rely on periodic stray radiation measurements, as well as on the film badge data. It is emphasized that using ionization chamber instrumentation to obtain estimates of the stray neutron fluxes in terms of equivalent Po-Be neutron fluxes is, on the other hand, conservative since neutrons in the PoBe energy range are regarded as the most hazardous. Furthermore, by inferring the importance of the fast neutron portion of the spectrum from strictly fast neutron measurements, it is believed confidently that the degree of conservatism in survey techniques will not become excessive.

In the high-energy ranges the picture appears to be less sanguine. The response of biological materials and survey instrumentation detectors to high-energy particles near meson producing devices is virtually unknown. It is hoped that the use of large quantities of moderating material in conjunction with the $\mathrm{BF}_{3}$ chamber, as well as nuclear track techniques and possibly threshold detectors, may eventually ease this problem. It was pointed out in Report NYO-4699 that linear energy transfer considerations indicate that very high energy particles are less deleterious to biological systems than lower energy particles of a higher specific ionization. However, it is emphasized once more that this conjecture should be examined carefully in view of the empirical data. Thus the recommendation that was made in Report NYO-4699 is repeated, namely, that research should be undertaken on the biological effects due to very high energy radiation, as well as on the necessary radiation dosimetry.

Increases in the efficiencies of existing particle accelerators, as well as the increase in the number of machines used in research and industry, indicate the need for a more serious consideration of shielding design. The survey experience has shown that the augmentation of the beam current of existing machines usually resulted in the need for additional shielding to offset the increased stray radiation levels. Often the supplemental shielding used up valuable floor space in accelerator experimental areas. Consequently adequate radiation shielding can be an important economic consideration, as well as simply one of radiation protection.

It is felt that a necessary condition for an adequate shield design is the attenuation of stray radiation levels in routinely occupied places to some fairly small fraction of the maximum permissible level. The effect of external radiation beams in these occupied areas should also be very small. Great care should be exercised in employing accelerator use factors and personnel work factors in permitting radiation levels above this fraction of the maximum permissible level. Many of the newer high-energy machines are actually in use much more than $40 \mathrm{hr} / \mathrm{wk}$, and often some of the personnel work for long periods of time on extended experiments. Consequently it is recommended that the attenuation afforded by a shield should be determined for the optimum beam condition, with respect to stray radiation levels, and for an occupancy factor of unity (i.e., the work areas are in use $40 \mathrm{hr} / \mathrm{wk}$. It is pointed out that the high cost of most accelerators necessitates almost continuous use as opposed to occasional use of the older machines.

The specific value of the fraction of the maximum permissible radiation level chosen by the shield designer should depend upon the individual site requirements. However, in view of the increases of beam currents accomplished in many existing accelerators, it is felt that shielding should be designed to permit no more than one-fourth the maximum permissible radiation level, or about $2 \mathrm{mrem} / \mathrm{hr}$. Fast neutrons appear to be the determining component of the stray radiations, and consequently a possible difficulty in radiation detection is emphasized. In the energy range 3 to $10 \mathrm{Mev}, 30 \mathrm{n} / \mathrm{cm}^{2}-\mathrm{sec}$ for $40 \mathrm{hr}$ is taken to correspond to $0.30 \mathrm{rem}$ in that period. ${ }^{10}$ Thus the fast neutron flux in areas adjacent to a shield designed according to the criteria discussed above would not exceed about $8 \mathrm{n} / \mathrm{cm}^{2}-\mathrm{sec}$, about the lower limit of the measuring ability of most existing portable fast neutron instruments. 
It is emphasized that reducing radiation levels to one-fourth the maximum permissible level is an inadequate criterion when uncontrolled areas are involved. Rather, the level in these places should not exceed one-tenth of the MPD, and actually the shielding should be designed to permit only a small fraction of one-tenth of the MPD.

Since the early work reported in Report NYO-4699, the accelerator survey technique has been greatly improved. Beginning in early 1953, the surveys conducted at 36 different machines have shown that the ionization chamber-vibrating-reed electrometer combinations have been particularly dependable even during surveys performed far from the New York area, as mentioned earlier. Consequently the bulk of the instrumental refinement or development work at HASL will consist in improving the ionization chambers. One type of chamber that is being considered for use as an $x$-ray dosimeter consists of an iron vessel filled with argon. This device is expected to have roughly only one-seventh the sensitivity to 4-Mev neutrons exhibited by the present graphite $-\mathrm{CO}_{2}$ chamber.

On a mass basis both chambers are equally sensitive to $x$ rays. Further work on the polyethylene-moderated $\mathrm{BF}_{3}$ chamber is also planned because of its sensitivity to scattered neutrons.

It had been hoped that the size of the instrumentation could be materially reduced. However, any such reduction seems unlikely until a portable battery-operated lightweight vibratingreed electrometer, or equivalent instrument capable of measuring $10^{-14}$ amp reliably, is de veloped for field use.

The possible importance of $r-f$ energy at high-energy machines in producing injury was discussed. ${ }^{1}$ No further work in this direction has been carried out; on the other hand, there have been no reported cases of $r-f$ injuries to accelerator personnel.

\section{REFERENCES}

1. L. R. Solon, J. E. McLaughlin, Jr., and H. Blatz, Stray Radiation Measurements at Particle Accelerator Sites, Report NYO-4699, June 1, 1956, p. 25.

2. H. R. Lang, editor, "Acceleration of Particles to High Energies," Institute of Physics, London, 1950.

3. M. S. Livingston, "High Energy Accelerators," Interscience Publishers, Inc., New York, 1954.

4. E. Segrè, editor, "Experimental Nuclear Physics," Vol. II, pp. 368, 413-415, John Wiley \& Sons, Inc., New York, 1953.

5. G. Failla and H. H. Rossi, Annual Report on Research Project, Report NYO-4523, June 1, 1953.

6. H. H. Rossi, G. S. Hurst, W. A. Mills, and H. E. Hungerford, Jr., Intercomparison of Fast Neutron Dosimeters, Nucleonics, 13(4): 46 (1955).

7. K. O'Brien and J. E. McLaughlin, Jr., Ionization Chamber Method of Measuring Mixed $\gamma-n$ Fields of Known Energy, Nucleonics, 15(1): 64 (1957).

8. G. J. Hine and G. L. Brownell, "Radiation Dosimetry," Chap. XV (H. H. Rossi), Academic Press, Inc., New York, 1956.

9. B. G. Whitmore and W. B. Baker, The Energy Spectrum of Neutrons from a Po-Be Source, Phys. Rev., 78: 799 (1950).

10. "Protection Against Betatron-Synchrotron Radiations up to 100 Million Electron Volts," National Committee on Radiation Protection, National Bureau of Standards Handbook 55, Feb. 26, 1954.

11. H. E. Johns "Physics of Radiation Therapy," Charles C. Thomas, Publisher, Springfield, Ill., 1953.

12. G. J. Rausa, Gamma Dose Rate from a Po-Be Source, Nucleonics, 12(2): 62 (1954).

13. B. W. Thompson, Portable Survey Meter for Fast and Slow Neutrons, Nucleonics, 13(3): 44 (1955); Report UCRL-2748.

14. W. F. Hornyak, A Fast Neutron Detector, Rev. Sci. Instr., 23: 264 (1952).

15. J. S. Handloser and W. A. Higinbotham, A High-sensitivity Fast Neutron Survey Meter, Rev. Sci. Instr., 25: 98 (1954).

16. G. S. Hurst, R. H. Ritchie, and H. N. Wilson, A Count-rate Method of Measuring Fast Neutron Tissue Dose, Rev. Sci. Instr., 22: 981 (1951). 
17. F. P. Cowan, Technical Discussion of the Brookhaven Off-site Personnel Monitoring Service, Ra-Det, 6: 23-30 (1953), Official Use Only.

18. W. E. Siri, "Isotopic Tracers and Nuclear Radiations," McGraw-Hill Book Company, Inc., New York, 1949.

19. H. Bass, H. DiGiovanni, and H. D. LeVine, Extrapolation Chamber Determination of Betaray Surface Dose Rate for Uranium and Some Uranium Compounds, Report NYO-57, Apr. $29,1949$.

20. "Permissible Dose from External Sources of Ionizing Radiations," National Committee on Radiation Protection, National Bureau of Standards Handbook 59, Sept. 24, 1954. 